Florida International University FIU Digital Commons

\title{
Assessing Sustainability of Sanitation Technologies Recommended for Rural Settings: A Case Study of Morogoro District, Tanzania
}

Amour Seleman

Florida International University, asele001@fiu.edu

DOI: $10.25148 /$ etd.FI12080612

Follow this and additional works at: https://digitalcommons.fiu.edu/etd

\section{Recommended Citation}

Seleman, Amour, "Assessing Sustainability of Sanitation Technologies Recommended for Rural Settings: A Case Study of Morogoro District, Tanzania" (2012). FIU Electronic Theses and Dissertations. 690.

https://digitalcommons.fiu.edu/etd/690 


\section{FLORIDA INTERNATIONAL UNIVERSITY}

Miami, Florida

\section{ASSESSING SUSTAINABILITY OF SANITATION TECHNOLOGIES \\ RECOMMENDED FOR RURAL SETTINGS: A CASE STUDY OF MOROGORO \\ DISTRICT, TANZANIA.}

A thesis submitted in partial fulfillment of the

requirements for the degree of

MASTER OF SCIENCE

in

ENVIRONMENTAL STUDIES

by

Amour Seleman

2012 


\section{To: Dean Kenneth Furton}

College of Arts and Sciences

This thesis, written by Amour Seleman, and entitled Assessing Sustainability of Sanitation Technologies Recommended for Rural Settings: A Case Study of Morogoro District, Tanzania having been approved in respect to style and intellectual content is referred to you for judgment.

We have read this thesis and recommend that it be approved.

\begin{tabular}{r} 
Raymond Scattone \\
\hline Krishnaswamy Jayachandran \\
Mahadev Bhat, Major Professor
\end{tabular}

Date of Defense: July 10, 2012

The thesis of Amour Seleman is approved.

$\begin{array}{r}\begin{array}{r}\text { Dean Kenneth Furton } \\ \text { College of Arts and Sciences }\end{array} \\ \hline \begin{array}{r}\text { Dean Lakshmi N. Reddi } \\ \text { University Graduate School }\end{array}\end{array}$

Florida International University, 2012 


\section{DEDICATION}

I dedicate this thesis to my wife Shamila Mwanga and my children Sheila, Fadhila and Fadhili in appreciation for all of their love, encouragement and patience. 


\section{ACKNOWLEDGMENTS}

I sincerely would like to thank my major professor, Dr. Mahadev Bhat, for his guidance, advice and direction for the development of this work, and for my entire academic program. I am very grateful to Dr. Krishnaswamy Jayachandran who in addition to serving on my thesis committee provided me with valuable support throughout my graduate program. I am also grateful to my committee member, Dr. Raymond Scattone, for his insight and helpful advice.

I also acknowledge the United States Agency for International Development (USAID) for granting me the scholarship and funding of this research. I'm indebted to Kimberlee LeBlanc and Specioza Machume, the coordinators of the USAID Leadership and Innovation Training Program. I am grateful to Dr. Maria Donoso, Dr. Elizabeth Anderson, Vivienne Abbott, Dolores Dominguez and Ana Lemos for their assistance through the Global Water for Sustainability Program (GLOWS) of the Florida International University.

I would also like to thank all those who participated in this study either as sources of information or data collection assistant, national sanitation and hygiene experts, staff at Morogoro District, and the people of Changa, Fulwe, Kalundwa, Kinole and Mkuyuni villages. Special thanks goes to Ally Msopa who helped with organizing the data collection activity in the district.

Finally, I sincerely appreciate my parents Ahmad Seleman and Tusekile Matipula for their love and prayers. I also extend my appreciation to the faculty, staff and all my friends at FIU, who have been a source of inspiration throughout my stay here in Miami. 


\section{ABSTRACT OF THE THESIS \\ ASSESSING SUSTAINABILITY OF SANITATION TECHNOLOGIES \\ RECOMMENDED FOR RURAL SETTINGS: A CASE STUDY OF MOROGORO \\ DISTRICT, TANZANIA. \\ by}

Amour Seleman

Florida International University, 2012

Miami, Florida

Professor Mahadev Bhat, Major Professor

The objectives of this study were to: assess the sanitation conditions and sustainability of sanitation technologies, using a comprehensive framework of sustainability indicators. A survey of 500 households and focus group discussions of 40 key informants were conducted in five villages. Ninety-six percent of the households had toilets, with only $9.4 \%$ having improved toilets. A strong relationship existed between the percent of sanitation coverage and the diarrhea incidence rates. Education and family wealth were the two significant determinants of sanitation coverage. On the basis of the sustainable development index, SanPlat and VIP latrine were the top two probable sustainable technologies. Variation did exist in the rankings of sanitation technologies across the study villages. Improvement in sanitation in rural Tanzania requires education of people about its health benefits, proper training, and extension of rural health workers. 


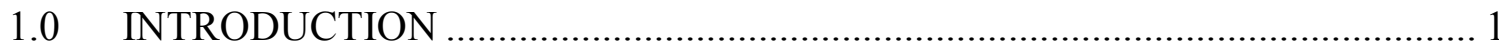

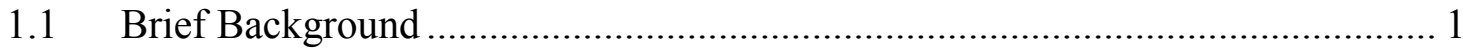

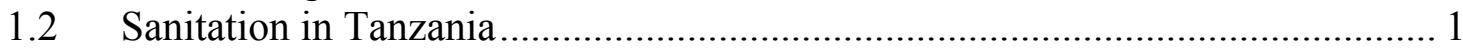

1.3 Statement of the Problem ………………................................................. 3

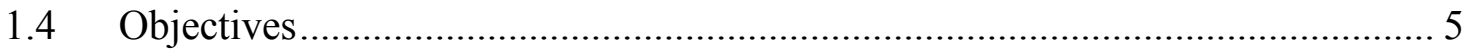

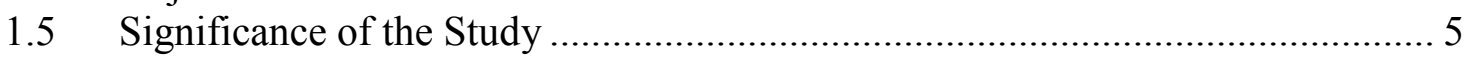

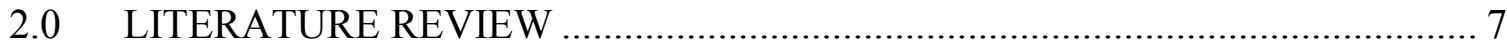

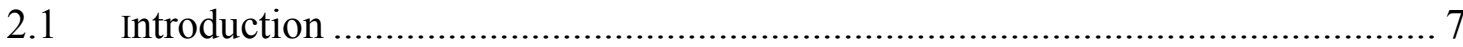

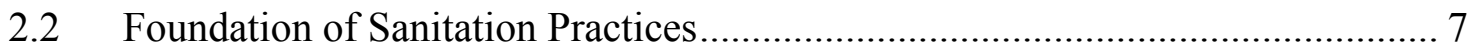

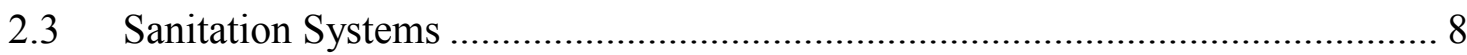

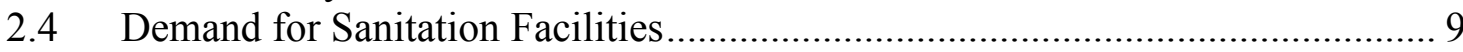

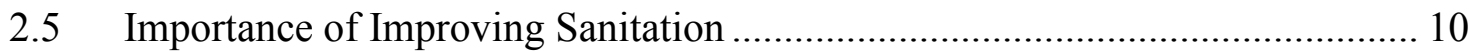

2.6 Interaction Between Sanitation, Hygiene and Water Supply............................. 11

2.7 Monitoring Access to Improved sanitation ........................................................ 11

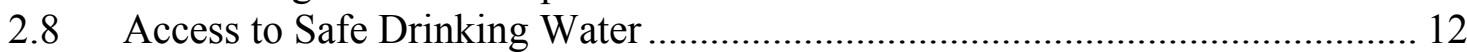

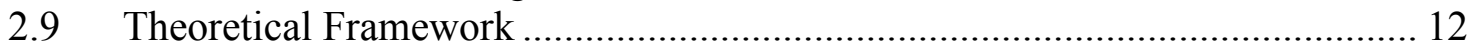

2.9.1 Adoption of Appropriate Technology …………........................................... 12

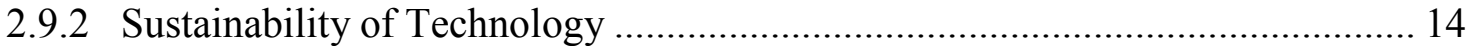

2.9.3 Sustainability of Sanitation Technologies...................................................... 14

2.9.4 Sustainability of Sanitation Technologies in Tanzania ....................................... 16

2.9.5 Selection of Sustainable Sanitation Technologies ............................................. 16

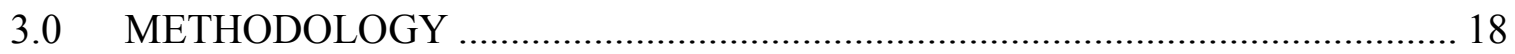

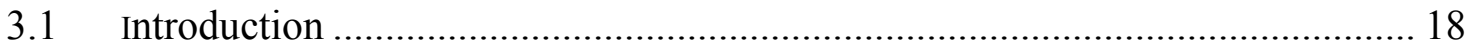

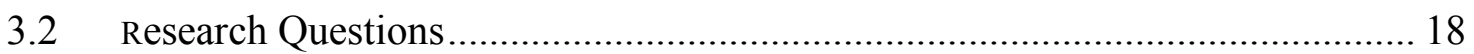

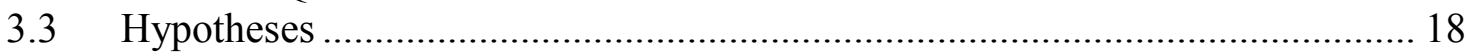

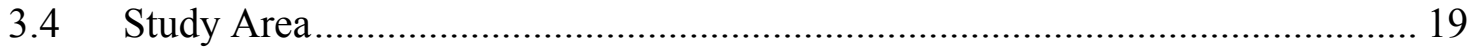

3.5 Chosen Sanitation Systems for Evaluation ................................................... 20

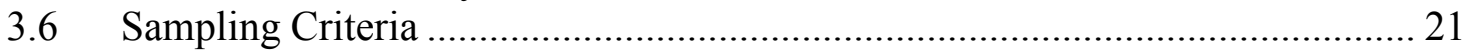

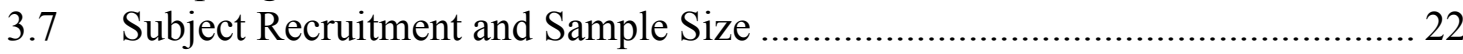

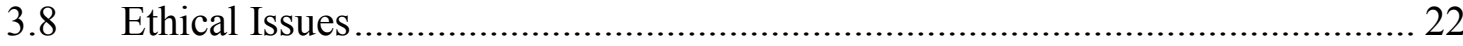

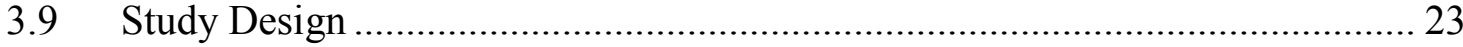

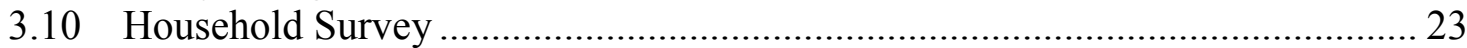

3.11 Assessing Socioeconomic Characteristics ……………………...................... 25

3.12 Sustainability Assessment and Ranking of Technologies.................................. 25

3.12.1 Selecting and Grouping of Sustainability Criteria and Indicators...................... 26

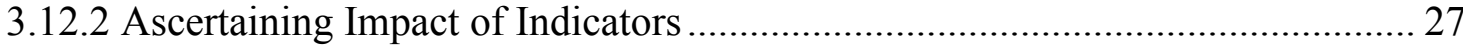

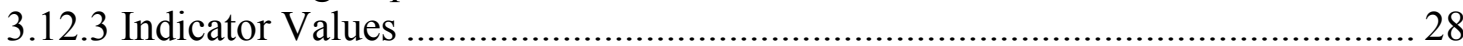

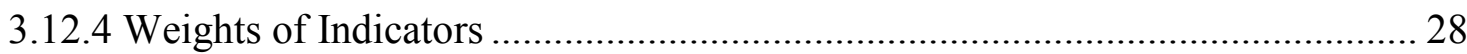

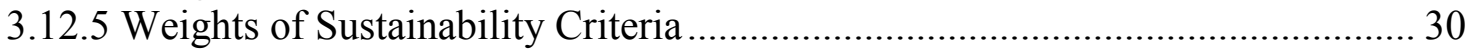

3.12.6 Checking Consistency of the Pair-Wise Matrix ................................................ 32 


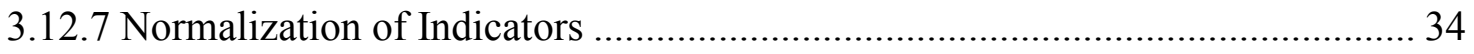

3.12.8 Calculation of Composite Sustainable Development Index............................... 34

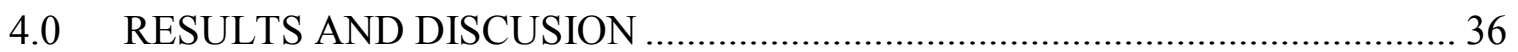

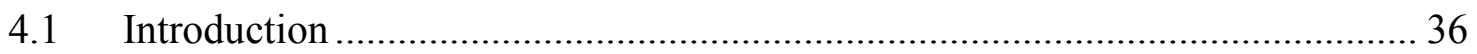

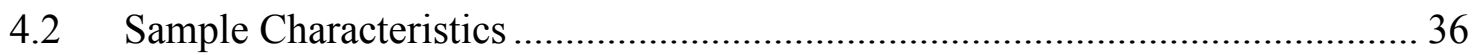

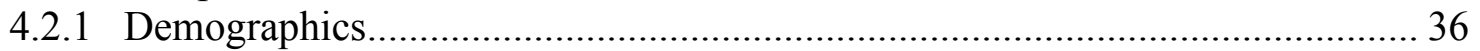

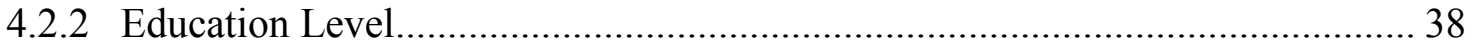

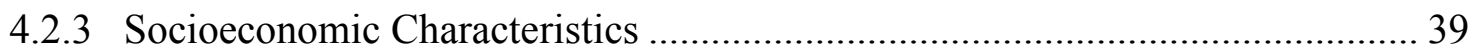

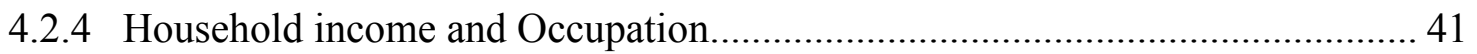

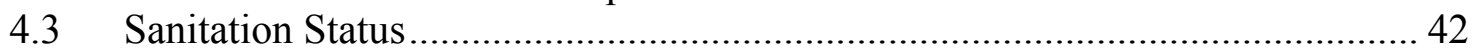

4.3.1 Socioeconomic Status and Use of Improved Sanitation ..................................... 44

4.3.2 Education Level and Use of Improved Sanitation ............................................. 45

4.3.3 Problems Associated with Existing Sanitation Technologies .............................. 45

4.3.4 Sanitation and Diseases Occurrence ................................................................ 46

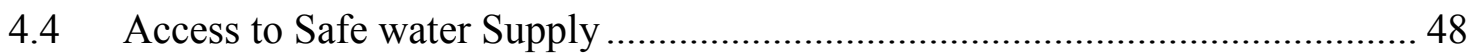

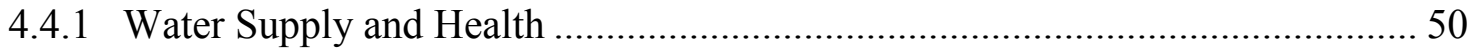

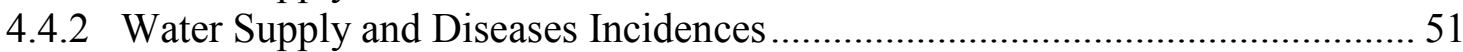

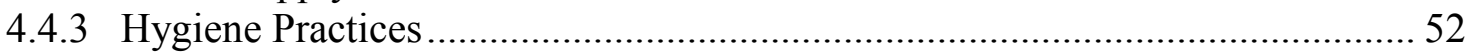

4.5 Environmental Characteristics ...................................................................... 52

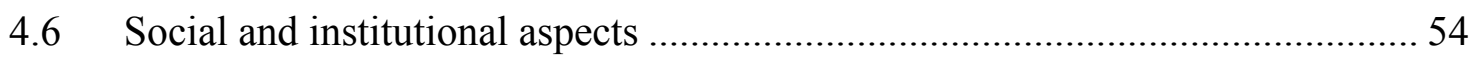

4.6.1 Perception of Villagers on Recommended Sanitation Technologies ................. 55

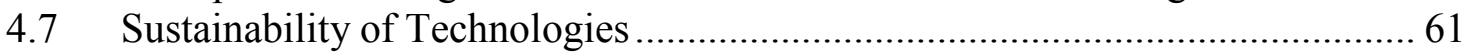

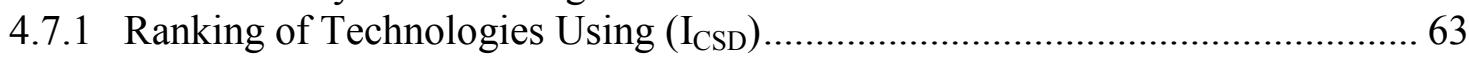

5.0 CONCLUSIONS AND RECOMENDATION ………………….......................6

5.1 Existing Sanitation Conditions and the Associated Problems ........................... 69

5.2 Factors Influencing Adoption of Alternative Sanitation Technologies ............. 70

5.3 Sustainability of Sanitation Technologies and Final Ranking ............................ 71

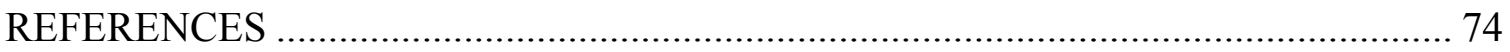

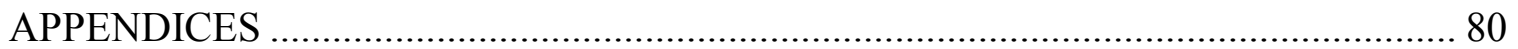




\section{LIST OF TABLES}

TABLE

PAGE

Table 1: Sustainability Criteria (sub-groups) and Indicators (sub-indices) .................... 27

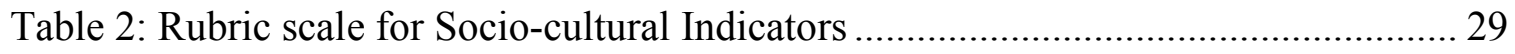

Table 3: Pair-wise matrix of Sustainability Factors................................................... 32

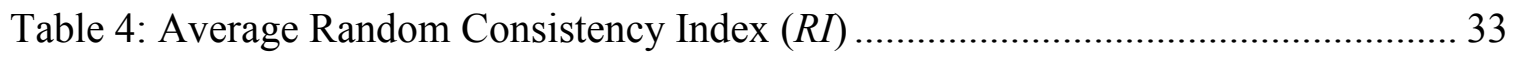

Table 5: Socioeconomic Status on Basis of Household Characteristics.......................... 39

Table 6: Estimated Costs of Sanitation Technologies in Surveyed Villages.................... 57

Table 7: General Perception About the Recommended Technologies ........................... 59 


\section{LIST OF FIGURES}

FIGURE

PAGE

Figure 1: Gender distribution in sampled villages ............................................... 37

Figure 2: Distribution of education level of participants in surveyed villages ................. 38

Figure 3: Distribution of socioeconomic characteristics ........................................ 40

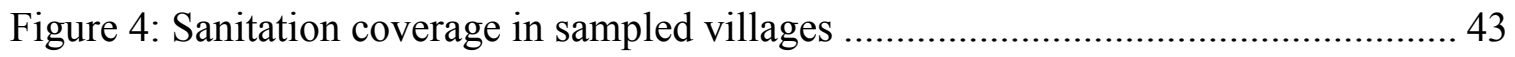

Figure 5: Diarrhea incidence rates and coverage of improved sanitation ...................... 47

Figure 6: Diarrhea incidence and coverage of improved sanitation in study villages..... 48

Figure 7: Access to safe drinking water in surveyed villages................................... 49

Figure 8: Distribution of sources of safe drinking water in surveyed villages ................ 49

Figure 9: Access to safe drinking water and diarrhea incidence rates ........................... 52

Figure 10: People's preference on recommended sanitation technologies......................57

Figure 11: Willingness to pay and cost of sanitation technologies in surveyed villages.. 58

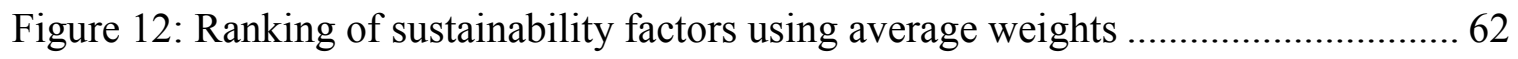

Figure 13: Ranking of sanitation technologies by $I_{C S D}$ in surveyed villages ................... 63

Figure 14: Ranking of sanitation technologies according to perception and $I_{C S D} \ldots \ldots \ldots . . .64$

Figure 15: Distribution of $I s$ values among technologies in Kinole/Tandai village ......... 65

Figure 16: Distribution of Is values among sanitation technologies in Mkuyuni village. 67

Figure 17: Distribution of $I s$ values among sanitation technologies in Kalundwa village 67

Figure 18: Distribution of $I s$ values among sanitation technologies in Kinole village..... 68 


\subsection{INTRODUCTION}

\subsection{Brief background}

A sustainable sanitation technology protects human health and does not contribute to environmental degradation or depletion of resource base (Kvarnstrom et al., 2004). Such a sanitation method must be technically feasible, economically viable and socially acceptable. The World Health Organization and United Nations Children's Fund called for promoting improved sanitation instead of simple latrines in 2004 (UN WWAP, 2006). By 2010, many developing countries had large populations with limited access to improved sanitation technologies (UN 2010). In Tanzania for example, only $22 \%$ of urban population and $9 \%$ of rural population adopted improved sanitation facilities by 2010 (NBS, 2010). Health officials and planners often grapple with the question why the adoption of improved and sustainable sanitation technologies has been slow in the developing world. There is no clear understanding whether and under what circumstances improved sanitation technologies receive public acceptance. The present study is an attempt to assess the feasibility and sustainability of alternative sanitation technologies in the context of Tanzania, using a comprehensive framework of sustainability indicators, representing environmental, health and socio-economic elements.

\subsection{Sanitation in Tanzania}

The popularity of sanitation in Tanzania traces its history back to the 1970 s during the famous health campaign, Mtu ni Afya (Man is Health), or simply cleanliness campaign (Hall, 1978). The campaign involved the most common activity of digging of 
toilets, along with other measures such as the use of mosquito nets and destruction of mosquito breeding sites. The success of this campaign was in part the result of the freedom given to households to choose whether to build a toilet or not. People were only informed of the importance of having a toilet ("uchaguzi ni wako"- it is your choice) without being forced to adopt one. Behind the success of the campaign was the control of diseases, which was one of the three national priorities among other ignorance and poverty reduction. The proportion of population with access to sanitation facilities increased significantly during the campaign, although the standard set for toilets were not reached by the majority of users (Hall, 1978).

Under the Health Policy of 2007, the government of Tanzania formulated guidelines, laws and standards for improved sanitation systems which are implemented through health education and enforcement of the public health laws. Although these regulations were passed, it was at a time when the sanitation sub sector still faced a number of challenges. Sanitation and hygiene still receive a low priority by potential users and decision makers (MoHSW, 2009). In many cases this challenge is associated with income and the expenditure pattern of households. More emphasis has been placed on public education and healthcare rather than improving sanitation infrastructure throughout the country. The lack of emphasis on the latter has been further exacerbated by blurred demarcation of roles and mandates by key public sectors. Furthermore, the number of people in need of improved sanitation is large; by 2010 about $90 \%$ of rural and $78 \%$ of urban residents still used unimproved sanitation technologies (NBS, 2010).

The government of Tanzania has adopted the Joint Monitoring Program (JMP) of the WHO and UNICEF proposed alternative types of improved sanitation technologies. 
My study evaluated the feasibility and sustainability of the proposed sanitation technologies using criteria that reflect social acceptance, economic viability, technical feasibility, environmental protection and institutional appropriateness in Morogoro District as a case study. The main premise of the study is that understanding local physical characteristics is just as important as technical and economic specifications of a given technology for ascertaining its sustainability. Findings from my study may provide baseline information on characteristics of communities in which improved sanitation technologies are being proposed.

\subsection{Statement of the Problem}

Reliance on unimproved sanitation facilities can be both an environmental and health hazard. Children living in households with poor sanitation are experiencing frequent diarrhea resulting in malnutrition and death (Checkley et al., 2004). Each year about 1.5 million children die of diarrhea disease globally (WHO, 2012). Use of improved sanitation technologies also not only pollutes surface and underground water but also leaves the entire community in environmental squalor (Knappett et al., 2011, Dzwairo et al., 2006, Lyimo et al. 2008). Adoption and use of improved sanitation facilities reduces the burden of disease associated with poor sanitation (WHO, 2004), and maintains a healthy environment.

Despite global, national, and regional efforts, a large proportion of the world's population in developing countries still relies on unimproved sanitation technologies. By 2010, an estimated 2.5 billion people were still without access to improved sanitation, a large proportion being people living in rural areas (UNICEF \& WHO, 2012). The low 
adoption of improved sanitation may in part be because some technologies fail prematurely, leading to wasted resource (Lockwood et al., 2010). In some places improved sanitation technologies receive low acceptance either because of local customs and behavior (Hall 1978, Chaggu et al., 2002) or local practices that determine whether or not to use excreta as agricultural fertilizer (Jensen et al. 2005). Environmental conditions like high water table limit adoption of improved latrines (Mtungila and Chipofya, 2009). The aforementioned factors continue to be challenges to accessing improved sanitation facilities, and have in some cases prevented their integrity and life when installed.

The main objective of a sanitation system is to protect and promote human health through provision of a clean environment and removing a portion of the disease transmission cycle. In a more holistic way, this may require that a sanitation technology to be economically viable, socially acceptable and technically and institutionally appropriate (Kvarnstrom et al., 2004, Katukiza et al., 2010, SuSanA, 2011). These determinants, however, differ from one place to the other, making an understanding of place specific factors necessary. My study evaluates sustainability of sanitation technologies in the Morogoro District of Tanzania using criteria that reflect social acceptance, economic viability, technical feasibility, environmental protection and institutional factors as a way to understand local factors that determine adoption and sustainability of alternative improved sanitation technologies that are proposed. 


\subsection{Objectives}

The overall goal of my study was to assess sustainability of sanitation technologies as recommended for rural areas based on a case study of Morogoro District specifically:

- To assess the existing sanitation conditions and the associated health, environmental and socio-economic problems in the study area;

- To determine the physical, environmental, and socio-economic characteristics as well as institutional factors influencing the adoption of alternative sanitation technologies; and

- To rank sanitation technologies based on composite sustainable development index values.

\subsection{Significance of the study}

In order for a sanitation technology program to be successful both locally and nationally, it is important for one to understand the inter-play of various physical and socio-economic factors, which ultimately determine the degree of technology adoption. The real challenge is that these factors vary widely across different parts of the country. The sustainability indicator framework developed in my study will serve as an objective tool for systematically comparing a range of technology options for areas with diverse environmental and socio-economic characteristics. Policy makers can rank available sanitation options for each district or village and then target their monetary and technical efforts to promoting only those technologies that are most likely to succeed in each and every district. 
The results of this study may have significant contribution to countries like Tanzania that implement nationwide sanitation program. With a case study of the Morogoro District, the findings will provide baseline information on characteristics of rural communities and feasible sanitation facilities suitable for rural settings. 


\subsection{LITERATURE REVIEW}

\subsection{Introduction}

The present chapter provides a summary and synthesis of various published works on improved sanitation and sustainability. It covers background on sanitation practices, systems and the linkage of sanitation to other aspects of community health and services. Theoretical framework, sustainability factors and methods of assessing sanitation systems are also discussed in this chapter. The discussion has been divided into several sections from foundation of sanitation practices to sustainability assessments in Tanzania.

\subsection{Foundation of sanitation practices}

Sanitation practices can be explained by looking at the evolution of the word sanitation as defined by the World Health Organization (1992). Sanitation refers to all conditions that affect health, including infection-causing dirt, drainage systems and handling of refuse from houses The definition was then expanded to environmental sanitation to include other environmental problems including control of community water supplies, excreta and wastewater disposal, refuse disposal, vectors of disease, housing conditions, food supplies and handling, atmospheric conditions, and the safety of the working environment.

Recently, there has been considerable awareness of community water supply needs and the potential threat of pollution from excreta and wastewater disposal. In 1986, a WHO Study Group revised the sanitation definition to refer solely to the means of collecting and disposing excrete and community liquid wastes in a hygienic way so as to 
protect health of individuals and the community as a whole (WHO, 1992). The later definition of sanitation is adopted in this study.

\subsection{Sanitation systems}

Sanitation systems can be divided into two categories, 'onsite' and 'offsite' systems. Onsite sanitation systems deal with human excreta at the point of generation (e.g., the household level). Onsite sanitation can further be classified into two main categories: wet system which requires water for flushing and dry system which does not require water for flushing. Onsite sanitation systems include pit latrines, septic tanks and other household level technologies that do not involve sewerage (IRC, 2012).

Offsite sanitation systems transport human excreta to another location for treatment, disposal or use. Offsite sanitation can also be further classified into two main categories of 'decentralized' and 'centralized' systems. Decentralized systems include systems in which groups of two or more houses are linked to a (small bore sewer) network leading to a communal treatment system whereas centralized systems consist of wastewater systems serving one or several communities. In most cases, decentralized systems represent an appropriate technological option for urban areas that face problems with high population density, but where financing capability limits acquisition of larger centralized treatment systems (IRC, 2012). In the developing world, for example, sewerage sanitation systems are impractical because of high investment and operation costs (Mara et al., 2007). On-site sanitation options with low operation and maintenance costs remain the most appropriate particularly for rural and unplanned settlements (Nelson and Murray, 2008). 


\subsection{Demand for sanitation facilities}

There is an equal demand for hygienic disposal of excreta and the promotion of health in both rural and urban areas of the developed and developing world. The rural parts of developing countries however, present high demands for improved sanitation (Hoko \& Hertle, 2006., UN, 2010). High demand of sanitation in rural areas of developing countries may be a result of a majority of the population (75\%) living in rural areas (Hoko and Hertle, 2006). Furthermore access to healthcare in rural areas is always limited as such impact of poor sanitation on community health may be higher (Global Alliance for Community Development, 2012).

Disparity in access to improved sanitation between urban and rural settings is still daunting at international and national levels; by 2010 about half of the developing world's populations were using improved sanitation yet only $40 \%$ of rural populations had access to improved sanitation technology (UN, 2010). In mainland Tanzania, in the same year - 2010 - access to improved sanitation was 35\% in urban and $23 \%$ in rural areas. The coverage of improved sanitation in rural area might continue to be behind urban coverage for national targets to improve sanitation in rural - in a period of five years (2010 to 2015) - is set lower than urban targets. In the National Strategy for Growth and Poverty Reduction II 2010, the plan is to increase coverage in rural from $23 \%$ in 2010 to $35 \%$ in 2015 , where as in urban, the target to reach is $45 \%$ from $27 \%$ in the same period. 


\subsection{Importance of improving sanitation}

Human excreta is associated with various diseases, especially gastrointestinal diseases and helminth infections. The overall objective of improving sanitation is to hygienically separate humans from contact with feces. Inadequate and insanitary handling of human feces can lead to ground pollution, contamination of water sources, and contamination of surfaces that come in contact with humans. Insanitary disposal of human feces also provides habitat for disease transmitting vectors like flies and mosquitoes. Intolerable nuisances of both odor and sight may also be experienced when excreta are insanitary disposed of.

Inadequate and insanitary handling of human feces leads to pollution of the ground, contamination of water sources and other surfaces that human come into contact with, and exposure to disease causing organisms. Insanitary disposal of human feces also provides habitat for disease transmitting vectors like flies and mosquitoes. Intolerable nuisances of both odor and sight may also be experienced when excreta are insanitary disposed of.

Fecal-oral related diseases often manifest in diarrhea (Thomas \& Weber, 2001). As such, diarrhea is an indicator of poor sanitation and a measure used to ascertain the impact of using proper sanitation facilities. Access to improved sanitation can reduce diarrhea morbidity by $32 \%(\mathrm{WHO}, 2004)$. As hygiene is part of proper sanitation, washing hands may lead to reduction of diarrhea disease by $45 \%$ (WHO, 2004). Many of the fecal -related diseases affect children in particular, it is estimated that each year, diarrheal disease kills 1.5 million children (WHO, 2012). 


\subsection{Interaction between sanitation, hygiene and water supply}

In achieving the goal of protecting humans from contact with excreta, sanitation technology offers a means for proper disposal of human excreta. Hygiene practices like hand washing with running water and soap ensure breakage of transmission routes of excreta related diseases. Even though the three components namely, sanitation, hygiene and water supply can be taken as individual packages of interventions, public health benefit is realized when the three are integrated (Eisenberg et al., 2007). In principle, benefits of water quality intervention are masked if sanitation conditions and hygiene practices are poor (Eisenberg et al., 2007).

The relationship between sanitation, hygiene and water supply, nonetheless, remains to be an area of further research (Howard and Bartram, 2003). Quantity of water adequate to achieve proper hygiene per capita per day has not been determined. The volume of water used by households depends on accessibility defined in terms of service level which is determined primarily by distance, time, reliability and potentially cost (Howard and Bartram, 2003). Requirements for water supply service levels can thus be categorized as no access, basic access, intermediate access and optima access.

\subsection{Monitoring access to improved sanitation}

The Joint Monitoring Program (JMP) of the WHO/UNICEF defines access to sanitation as proportion of people with access to either of the following improved sanitation technologies: flush/pour flush toilet connected to piped sewer system or septic tank or pit (latrine), ventilated improved pit latrine, pit latrine with slab or composting 
toilet. The above technologies hygienically separate human excreta from human contact (WHO/UNICEF-JMP, 2010).

Access to sanitation is expressed in terms of proportional of people with access to proper sanitation. The data on access is a representative of number of households that use improved sanitation systems. The definition of households however varies (Leone et al., 2010). My study adopted a the Tanzania National Bureau of Statistics (NBS) definition that define household as a person or group of persons, related or unrelated who live together and share a common source of food.

\subsection{Access to safe drinking water}

A community is regarded as having access to safe drinking water if it obtains water from improved sources, a source that, by nature of its construction or through active intervention, is protected from outside contamination, in particular from contamination with fecal matter (WHO/UNICEF-JMP, 2010). As such traditional sources like rivers, ponds, and unprotected springs are excluded from the list of sources of a supply of safe water.

\subsection{Theoretical framework}

\subsubsection{Adoption of appropriate technology}

Planners often grapple with the question why the adoption of sanitation technologies is slow especially in the developing world. There exists a vast literature on the concept and practice of 'appropriate technology' that would shed some light on this question. Diwan et al., (1979) notes that the appropriate technology sometimes refers to an entire social movement that leads to the adoption of a collection of hardware (such as 
machines, products, infrastructures-roads, water distribution system) and/or to the design alternatives presumably responsive to the ideology of that movement. For instance, the Gandhian movement of promoting small-scale, cottage industries in India was an example of appropriate technology. According to Jequier and Gerard (1993), appropriate technologies are generally characterized by one or more of the following features: (i) low investment cost per work place; (ii) low capital investment per unit of output; (iii) organizational simplicity; (iv) high adaptability to a particular social cultural environment, (v) sparing use of natural resources; and (vi) low cost of final product or high potential for employment. Therefore, the improved sanitation technologies to be appropriate and successful in rural Tanzania will first have to meet the above broad characteristics.

When a new technology is introduced into an area, the adoption will be slow until that region reaches a level of development that can take advantage of the technology being introduced (Basu and Weil, 1998). Further, slow adoption of technology is brought about by the barriers that lead to increased cost of technology adoption. Consequently, a technology will diffuse in an area only when barriers to adoption are reduced (Parente and Prescott, 1994).

One way to facilitate technology transfer is through identifying barriers for its adoption. Understanding local constrains on introduction of a technology through trial and error technique and devising of a mechanism that facilitates a two way exchange of information between user and designer of the technology are essential. In such a system, users provide feedback on the performance of introduced technology. Such feedback is used to redesign or in other ways to improve the technology in order to increase users' 
satisfaction (Murphy et al., 2009). This study is an attempt to understand local problem and ascertaining the most probable technology that can be introduced. Assessing a technology appropriate to an area is not a straightforward process; one must consider available resources, local preference, time, and place (Murphy et al., 2009).

\subsubsection{Sustainability of technology}

Increased concern about availability of resources in the future shapes the way a technology is regarded as an appropriate. Van der Vleuten-Balkema (2003) in Malisie A. (2008) considers sustainable technology as technology that does not threat the quantity and quality of the resources and have the lowest cost with respect to the physical, sociocultural and economic environments. Equally important is to recognize the importance of sustainability of services provided by the technology itself otherwise an appropriate technology may turn to be environmental and health hazard to present and future generations (Malisie A, 2008).

\subsubsection{Sustainability of sanitation technologies}

The sustainability of sanitation technology has two meanings: environmentally sustainability and locally sustainability (Murphy et al., 2009). The first implies the system that does not cause significant harm to the environment and allows current needs to be met without compromising the needs of the future generations. Local sustainability of technology implies ability of local users to maintain, reproduce and repair the newly introduced sanitation technology after outside designers have left the community (Murphy et al., 2009). 
Assessment of sustainability of sanitation technology takes into consideration both meanings of sustainability. Environmental sustainability and local sustainability as a result become part of the four fundamental principles of sustainable sanitation technology. The four fundamental principles of sustainability are human health protection, affordability, environmental sustainability and institutional appropriateness (Mara et al., (2007).

Sustainability criteria are the set of criteria that facilitate evaluation of technologies to ascertain their sustainability. The four principles of sustainability lay a foundation for developing sustainability criteria. Thus sustainable sanitation technology can be defined as the technology that protects and promotes human health, protects the environment from degradation or depletion of the resource base, is technically and institutionally appropriate, economically viable and socially acceptable (Kvarnstrom et al., 2004, Katukiza et al., 2010, SuSanA, 2011). The characteristics of sustainable sanitation included in the definition forms set of criteria upon which sanitation technologies are assessed.

It is considered that, sanitation arrangements, if properly designed, implemented, operated and maintained, can improve community health (Feachem et al.., 1983), as a result during assessment the health aspect criterion is either imbedded in environmental protection criteria (Katukiza, et al. 2007) or is left un mentioned (Mara et el, 2007). The assessment is then done using four criteria of affordability, socio-cultural acceptability, technical feasibility and environmental impact and reuse potential (Mara et al., 2007). I use the same categorization in my research. 


\subsubsection{Sustainability of sanitation technologies in Tanzania}

There are few published works on sustainability of sanitation technologies in Tanzania. Chaggu et al. (2002) assessed socio-cultural and socioeconomic situations with regard to excreta disposal in the most urbanized city of Tanzania, Dar es Salaam. The study revealed that habitual behavior hinders the use of new technologies like ecological sanitation. A study conducted by Lyimo et al. (2007) on community awareness on microbial water pollution and its effects on health development in urban Tanzania, found that fecal contamination of wells is high which is largely the result of the use of pit latrines. Igulu (2010) found that advocacy for proper sanitation will have significant impact in reduction of diarrhea in children less than five years old. A majority of sanitation-related studies were conducted only in urban areas (e.g., Dar es Salaam). Also, these studies did not address whether alternative sanitation technologies are likely to solve existing problems sustainably. In 2003, WaterAid-Tanzania in collaboration with London School of Hygiene studied determinants of sustainable sanitation in Dodoma district; the study assessed factors affecting sustained adoption of any type of toilets (McCubbin N.C., 2007). My study in hand assessed sustainability of alternative types of improved toilets recommended for rural setting and came up with a rank of sanitation technologies according to sustainability index.

\subsubsection{Selection of sustainable sanitation technologies}

Selection of sustainable sanitation technology especially in developing countries is a complex process for communities are socio-economically inhomogenous (Loetscher and Keller, 2002). In such environment, technology selection may require consideration 
of several criteria in an algorithms or any other decision aids approach until the most feasible technology is identified (Loetscher and Keller, 2002., Mara et al. 2007). Whichever method is employed its useful to understand the extent to which each criteria is met in any given situation in scale (Mara et al. 2007).

In ground of so many indicators it may be difficult to evaluate performance and that integration of indicators is one of the ways out. Krajnc and Glavic (2004) proposed a model that indicates how to integrate indicators in order to determine sustainable development in a manner that facilitates decision making process. The method focus on integrated assessment on the company level, in this study the same model has been used to evaluate sustainability of alternative sanitation technologies. 


\subsection{METHODOLOGY}

\subsection{Introduction}

Chapter three begins with a list of research questions and the study hypotheses. I will then present an overview of the study area. The subsequent section will describe the methodology used to test the hypothesis. There are also sections on data collection, data analysis, ethical clearance and assessment of sustainability of sanitation technologies and final ranking.

\subsection{Research Questions}

The current research attempts to address the following research questions:

- What are the current sanitation practices and conditions in the study area?

- What are the problems associated with the current sanitation technologies used in the area, including diseases, pollution, pests (e.g., rats, insects), aesthetics (e.g., smell, appearance, etc.)?

- What are the social, economic, institutional and physical determinants for adopting sanitation technologies?

- What sanitation technology is suitable for each study village?

\subsection{Hypotheses}

Hypothesis 1: Sociocultural lifestyle of people compounded with habitual behavior and low education level is expected to lead to the existing sanitation condition.

Hypothesis 2: Low economic wellbeing brought about by high level of poverty leads to poor sanitation. 
Hypothesis 3: Limited access to adequate quantities of water affect adoption of water-based sanitation technologies.

Hypothesis 4: Geologic soil structure of the physical environment that has hard rock, a high water table and loose soil leads to adoption of poor sanitation technologies.

Hypothesis 5: Physical, socio-cultural, economic and institutional characteristics of the area favor introduction and adaptation of recommended new sanitation technologies.

Hypothesis 6: Technical complexities of technology determine the extent of their adoption and people's ability to sustain their use.

\subsection{Study area}

My study took place in Morogoro district, Tanzania (Figure 1). The district is located northeast of the Morogoro Region between Latitude $8^{\circ} 00^{\prime}$ and $6^{\circ} 45^{\prime}$ south of equator and between Longitude $37^{\circ} 00^{\prime}$ and $38^{\circ} 30^{\prime}$ east. It borders the Pwani region in the east, the Kilombero district in the south, and the Mvomero district in the south, west and north. It covers an area of $11,925 \mathrm{Km}^{2}$ and $60 \%$ of its area is covered by vegetation, forest, and the Selous Game Reserve. On the basis of 2002 National Census, the district is estimated to have a population of about 283,858 of which about $90 \%$ are farmers/peasants.

Administratively the Morogoro District is divided into six Divisions, 29 Wards, 141 villages, and 56,723 households. The district is dominated by one ethnic group, the 
Luguru. For the purpose of this study, I chose the villages of Changa, Fulwe, Mkuyuni, Kalundwa and Kinole/Tandai.

Figure 1: Map of the study area: Morogoro district, Tanzania
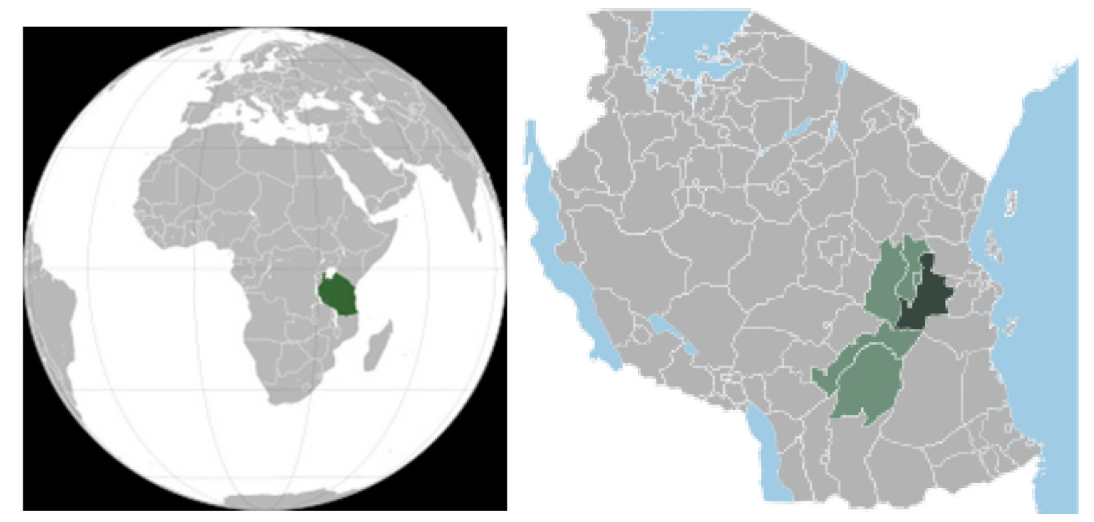

Source: wordlessTech.com and http://en.wikipedia.org/wiki/Morogoro_Rural

\subsection{Chosen sanitation systems for evaluation}

The study involved the study of five sanitation technologies; improved floor toilet, sanitation platform (SanPlat), ventilated improved pit latrine (VIP latrine), pour flush latrine (with water seal) and ecological sanitation (EcoSan) with urine diversion. Sanitation Platform (SanPlat), VIP toilets, and pour flush are the technologies recommended by the national Government. Ecological sanitation (Ecosan) was included in this study as a new technology believed to be environmentally friendly, while the improved floor toilet was chosen as a technology commonly used in Tanzania. The technology includes a cement floor that can be washed.

All the five sanitation technologies are onsite sanitation technologies, which basically have three components in common: a pit, a floor and a superstructure. Technologies were also distinguished by different characteristics, namely, how they controls odor, and their water requirement among other features. Since all technologies were pit latrine and that 
superstructure can be the similar to all technologies, evaluation focused on floor/slab and other accessories that make one technology different from the other. However during estimation of cost, the pit feature was included because one of the technologies did not require a pit (Ecosan), and its cost could not be broken into components like other technologies. A more description of each technology involved in the survey is attached in Appendix I.

The cost of a particular technology was estimated on the basis of the quantity of material estimated by WaterAid Tanzania, a non government organization that run a sanitation center in Tanzania where different types of sanitation technologies are constructed for demonstration. The cost of ecological sanitation technology was estimated by Environmental Engineering and Pollution Control Organization (EEPCO), the pioneer of EcoSan in Tanzania.

With an option of improved slabs, this study chose ferrocement slab to estimate the cost of floor for both VIP latrine and Pour flush. A pour flush toilet used for the assessment was the one in which the slab and the squatting pan rested over the pit. The decision was taken because of a lack of information on costs of pipes if the pit is offset.

\subsection{Sampling criteria}

The study recruited household leaders, head of department and/or senior staff nominated by particular institution to participate in the survey to represent the institution. All subjects recruited were adults aged 18 years and above. Five villages were selected in consultation with key informants or village leaders. Within these villages, the same criteria were used to select sub -villages to be involved in the study, i.e., sub-villages 
were chosen randomly from the list of villages to represent others. In sub villages, households were selected randomly, making sure that at least one household was skipped between two interviewed households.

In Focus Group Discussion (FGD), participants were identified with consultation with village leaders. Participants were then visited to their homes or informed using mobile phones for those who had cell phone.

\subsection{Subject recruitment and sample size}

A total of 540 participants were recruited in this study of whom 500 participated in the household survey and 40 participated in FGDs, eight individuals in each village. Focus group discussion participants were diverse and included village artisans, women, senior people, and village elders who were familiar with local customs. Also included were individual with houses without toilet and individual with improved sanitation technology. Participants were selected in consultation with sub-village leaders - village executive officers.

\subsection{Ethical issues}

Ethical clearance to use human subjects was obtained from the Institutional Review Board (IRB) of the Florida International University (FIU - IRB Exemption number 062911-00) Ethical clearance was also sought from Tanzania where the study was conducted. The ethical clearance in Tanzania was issued by the National Institute for Medical Research and the Ministry of Health and Social Welfare. Ethical clearance in Tanzania gave the study eligibility to use indigenous people as source of information for a research conducted by foreign institution. 


\subsection{Study design}

The present study was cross sectional in nature, representing diverse socioeconomic and physical-environment characteristics of the study area. The major task was to identify suitable criteria for assessing sanitation technology. Mara et al. (2007) identified four basic principles for choosing a sustainable sanitation technology: (i) human health, (ii) affordability, (iii) environmental sustainability. and (iv) institutional appropriateness. These principles also yield five criteria that facilitate sustainability assessment, as described by Sustainable Sanitation Alliance (SuSanA, 2011). These criteria include health impact, environment and natural resources impact, technology and operation, financial and economic considerations, and social cultural and institutional issues. The same criteria were adopted by this study.

Assessment of sustainability defined by the above identified criteria was done in three steps. The first step involved conducting a household survey to obtain baseline data. Second, I developed a database that enabled comparison between characteristics of given technology and physical characteristics of the area. At this step, judgment on the impact of technology whether positive or negative was made, and weights were assigned. In the final step, I compared sustainability of each sanitation technology using a model for integrated assessment of sustainable development.

\subsection{Household survey}

Various techniques were employed during the household survey to obtain baseline information to meet the study objectives. Interview with household heads and other key informants was done using pre-tested questionnaires with both open and closed questions, 
see appendix II. A transient walk was conducted to observe existing sanitation status. The household survey explored type of sanitation technologies currently used, practices, and problems associated with a particular technology. The questionnaire also explored sustainability related information including environmental characteristics, social economic status, and access to services (e.g., water and health). Geographic and environmental information like soil type (sandy or rocky) and ground water table (shallow or deep) were also collected in this stage. Documents providing information on sanitation services were also collected; consultation with various departments in the district was made for more clarification and issues that had no data. Data on disease incidences were obtained from disease surveillance system because they were most reliable than participants reporting to researchers. Some respondents were shy to acknowledge that if they had contracted diarrhea, as diarrhea was perceived as disease of the dirt. Incidence rate was calculated using new cases reported between January and March 2011, and the village population as reported in the district socioeconomic profile of 2011.

Focused Group Discussions (FGD) were conducted to find out user's perception on proposed sanitation technology, estimated costs and willingness and ability to pay for each particular technology. In FGD, the five sanitation technologies were presented as pictures (information and education material). Explanation of their working principles, and their advantage and disadvantage was made according to literature and national guidelines. The discussion yielded acceptance and rejection criteria as well as willingness to pay for a particular sanitation technology. During this discussion, information on the overall socioeconomic status of households was gathered; the socioeconomic data were 
used to categorize households into three categories: extremely poor, poor and rich. Categorization was made on the basis of building material used to construct wall, roofing and floor. The above household economic classification was later used to identify whether the households belonging to a given economic group will afford a given sanitation technology. Information was recorded and transcribed.

\subsection{Assessing socioeconomic characteristics}

In assessing household socioeconomic characteristics, the study assessed socioeconomic position on the basis of housing quality and asset ownership. The assessment helped to link housing, level of sanitation technologies and the community's ability to support financially and maintain such a technology.

Household quality was characterized by type of roofing material, wall and floor which later was used to categorize individual family as extremely poor, poor, least poor or well off. The categorization of socioeconomic status on the basis of housing quality was performed by residents in a focus group discussion.

\subsection{Sustainability assessment and ranking of technologies}

Sustainability assessment of technology was performed as a way to meet objective three by ranking sanitation technologies on the basis of composite sustainable development index values. The composite sustainable development values were obtained using the model for integrated assessment of sustainable development described by Krajnc and Glavic (2004). The model enables comparison of multiple technologies through computing a composite sustainable development index $\left(I_{C S D}\right)$ from more than one 
sustainability dimension. Each dimension/criterion has multiple indicators which are to be identified and grouped as sustainability sub-index $\left(I_{S}\right)$.

The overall assessment of sustainability, using the above model for integrated assessment of sustainable development, is a stepwise process that starts with grouping of criteria, followed by selecting indicators and judging their impact whether positive or negative. Finally, the composite sustainability index $\left(I_{C S D}\right)$ is calculated through aggregation of sustainability sub-indices $\left(I_{S}\right)$ using the following formulae:

$$
I_{C S D}=\sum_{j}^{n} W_{j} \cdot I_{S, j}
$$

Where $W_{j}=$ a weight of sub-group $j ; I_{S, j}=$ sustainable index for sub-group $j ; j=1, \ldots 4$ are the sustainability sub groups, namely health, environment, technical aspect, economic and social.

\subsubsection{Selecting and grouping of sustainability criteria and indicators}

Four groups of sustainability criteria of social cultural and institutional issues, technical factors, economic, and environment and natural resource protection were selected on basis of the literature mainly from the Sustainable Sanitation Alliance (SuSanA) website, Katukiza et al., (2010), and Mara et al. (2007). The criteria had more than one indicator however, only those that were easy to assess with given time and financial resources were selected and included in this study. There were four socio cultural indicators, 4 technical feasibility indicators, 3 environmental indicators and 3 economic indicators (see table 1). 
Table 1: Sustainability criteria (sub-groups) and indicators (sub-indices)

\begin{tabular}{|c|c|c|}
\hline $\begin{array}{c}\text { Sustainability } \\
\text { criteria-subgroups } \\
\left(j_{1-4}\right) \\
\end{array}$ & $\begin{array}{l}\text { Indicators- } \\
\text { Sub-indices }\left(I_{s}\right)\end{array}$ & Description \\
\hline \multirow[t]{4}{*}{$\begin{array}{l}\text { 1. Social cultural } \\
\text { and institutional } \\
\text { aspects }\end{array}$} & Convenience & $\begin{array}{l}\text { How convenient is the technology for } \\
\text { various groups in the community-people } \\
\text { with disability, young children, and } \\
\text { grownup girls }\end{array}$ \\
\hline & Conformity & $\begin{array}{l}\text { How the technology conform with local } \\
\text { practices and belief }\end{array}$ \\
\hline & Usability & $\begin{array}{l}\text { How easy it is to use the proposed facility as } \\
\text { viewed by the intended beneficiaries }\end{array}$ \\
\hline & Acceptability & $\begin{array}{l}\text { Perception, how people perceive of the } \\
\text { technology }\end{array}$ \\
\hline \multirow{4}{*}{$\begin{array}{l}\text { 2. Technology and } \\
\text { operation/ } \\
\text { Technical } \\
\text { factors }\end{array}$} & $\begin{array}{l}\text { Availability of } \\
\text { material locally }\end{array}$ & $\begin{array}{l}\text { Availability of local materials for facility } \\
\text { construction }\end{array}$ \\
\hline & Local skills & $\begin{array}{l}\text { Capacity of local artisans to undertake the } \\
\text { associated technical works }\end{array}$ \\
\hline & $\begin{array}{l}\text { Fresh water need } \\
\text { for operation and } \\
\text { hygiene }\end{array}$ & $\begin{array}{l}\text { Quantities of water required to run the } \\
\text { technology }\end{array}$ \\
\hline & Compatibility & $\begin{array}{l}\text { Compatible with local available material for } \\
\text { construction and running the technology, } \\
\text { e.g., type of washers required }\end{array}$ \\
\hline \multirow{3}{*}{$\begin{array}{l}\text { 3. Environmental } \\
\text { and Natural } \\
\text { resource } \\
\text { protection }\end{array}$} & Impact on forestry & Forest products required (trees) \\
\hline & $\begin{array}{l}\text { Pollution risk of } \\
\text { water sources }\end{array}$ & $\begin{array}{l}\text { Risk of emission of pollutants to the } \\
\text { environment such as nutrients and organic } \\
\text { matter }\end{array}$ \\
\hline & Nutrient recovery & $\begin{array}{l}\text { Possibility of nutrient recovery from } \\
\text { proposed technology for agricultural use. }\end{array}$ \\
\hline \multirow{3}{*}{$\begin{array}{l}\text { 4. Economic and } \\
\text { Financial } \\
\text { aspects }\end{array}$} & Willingness to pay & Willingness to pay full investment cost \\
\hline & $\begin{array}{l}\text { Ability/capacity to } \\
\text { pay for } \\
\text { improvement }\end{array}$ & $\begin{array}{l}\text { People's ability to pay for investment and } \\
\text { running costs }\end{array}$ \\
\hline & $\begin{array}{l}\text { Material recovery/ } \\
\text { Re use potential }\end{array}$ & $\begin{array}{l}\text { Possibility of reuse of construction material } \\
\text { (slab) }\end{array}$ \\
\hline
\end{tabular}

\subsubsection{Ascertaining impact of indicators}

In each group there are indicators that their increasing value has a positive impact

$\left(I_{A}^{+}\right)$and there are indicators that their increasing values have negative impacts $\left(I_{A}^{-}\right)$ 
from the perspective of sustainability. For example under environmental and natural resource protection, demand for forestry product has negative impact while nutrient recovery has positive impact.

\subsubsection{Indicator values}

Indicator values are usually obtained by measuring the impact either through routine monitoring or survey (Krajnc and Glavic, 2004). In the study area however, there was no monitoring data that measured indicator value that could show impact. For that case, a valuation rubric was developed for each indicator. The rubric values were derived from matching requirements of the technology against local conditions or situations. In all cases, variation in local situation and characteristics of technologies formed a basis for defining a scale. The rubrics scale varied among indicators with scale ranging from 0 to 5 or from 1 to 2 being used in such a way that small number is low (inferior) and large number is higher (superior). Table 2 provides an example of how rubric was formed. Rubrics for other sustainability criteria are given in Appendix III.

\subsubsection{Weights of indicators}

In order to further aggregate indicators within each criterion and sub-group

indicators into the final aggregate indicator, it was necessary to assign appropriate weights for different sustainability indicators within each criterion. The assumption was made that all indicators under criteria may not have equal importance in the eyes of the households or other stakeholders. Therefore, the next step in the developing the sustainability assessment of the sanitation technology was to develop weight of importance or significance for each sustainability indicator. These weights can be 
obtained through pair-wise comparison of factor in Analytical Hierachy Process (AHP) (Saaty, 1980). For the purpose of this study, weights of indicators under each criterion (social, environmental or technical) were assumed to be equal and their sum total of weights was set to be one. In this way the weight 1 was distributed equally among indicators in criteria except for acceptability indicator that had higher value (40\%) of the total weight. This is because accepting a technology was taken as very important step in adopting new sanitation technology.

\section{Table 2: Rubric scale for socio-cultural indicators}

\begin{tabular}{|c|c|c|c|}
\hline Indicators & Explanation & Description for rating & Unit \\
\hline \multirow[t]{3}{*}{ Convenience } & \multirow{3}{*}{$\begin{array}{l}\text { Technology easy to be } \\
\text { used by all family } \\
\text { members especially } \\
\text { growing children and } \\
\text { people with disability }\end{array}$} & $\begin{array}{l}\text { Technology features may limit young } \\
\text { children, people with disability }\end{array}$ & 0 (low) \\
\hline & & $\begin{array}{l}\text { Residents accept the technology with its } \\
\text { limitation }\end{array}$ & 1 \\
\hline & & $\begin{array}{l}\text { All members in family/ Society can } \\
\text { access with or without slight modification } \\
\text { of a technology }\end{array}$ & 2(high) \\
\hline \multirow[t]{5}{*}{ Conformity } & \multirow{5}{*}{$\begin{array}{l}\text { Conform with local } \\
\text { perception on material } \\
\text { used to construct a } \\
\text { technology }\end{array}$} & $\begin{array}{l}\text { Number of } \mathrm{HH} \text { with cement floor are } 50 \% \\
\text { and above, highly conform with housing } \\
\text { condition }\end{array}$ & 4 \\
\hline & & $\begin{array}{l}\text { HH with cement floor } 30-49 \% \text {, conform } \\
\text { with housing condition }\end{array}$ & 3 \\
\hline & & $\begin{array}{l}\text { HH with cement floor } 20-29 \text {, conformity } \\
\text { with housing condition is low }\end{array}$ & 2 \\
\hline & & $\begin{array}{l}\text { HH with cement floor } 10-19 \% \\
\text { conformity is very low }\end{array}$ & 1 \\
\hline & & $\begin{array}{l}\text { HH with cement floor } 0-9 \% \text { conformity is } \\
\text { extremely low }\end{array}$ & 0 \\
\hline \multirow[t]{4}{*}{ Acceptability } & \multirow[t]{4}{*}{ Acceptance } & Acceptance $81-100 \%$ & 5 \\
\hline & & Acceptance $71-80 \%$ & 4 \\
\hline & & Acceptance $51-70 \%$ & 3 \\
\hline & & Acceptance $0-50 \%$ & 1 \\
\hline \multirow[t]{3}{*}{ Usability } & \multirow[t]{3}{*}{$\begin{array}{l}\text { Similarity to common } \\
\text { practice (anal cleansing } \\
\text { practices) }\end{array}$} & $\begin{array}{l}\text { Anal cleansing practices on new } \\
\text { technology is similar to current anal } \\
\text { cleansing practice }\end{array}$ & 2 \\
\hline & & $\begin{array}{l}\text { Anal cleansing practices on new } \\
\text { technology is different from common } \\
\text { practice however the existing practice is } \\
\text { due to limitation of existing technology } \\
\text { than customs (User friendly) }\end{array}$ & 1 \\
\hline & & $\begin{array}{l}\text { Technology introduce new practices on } \\
\text { anal cleansing never practices before in } \\
\text { locality (Not user friendly) }\end{array}$ & 0 \\
\hline
\end{tabular}




\subsubsection{Weights of sustainability criteria}

The sustainability sub-index $\left(I_{S}\right)$ is obtained by multiplying the weight of criteria and the normalized value of indicators. Normalization of indicators is discussed in the next sub-section. Weights of criteria can be obtained from environmental impact assessment or through pair-wise comparison of factors/criteria through the analytical hierarchy process (Saaty, 1980; Krajnc and Glavic, 2004). In the study area however, environmental impact of sanitation technologies is yet to be determined, and therefore, weights were obtained through pair-wise comparison of criteria. Eight national sanitation stakeholders working in the areas of environment, health and water supply were used to perform ranking of criteria in a pair-wise fashion.

In a pair-wise comparison, two factors are compared at once by answering the question that which of the two criteria, $i$ and $j$, is more important than the other with respect to the sustainability of sanitation technologies. Krajnc and Glavic (2004) used a factor scale from 1 to 9 in order to express the judges' preference intensity. That is, a value of 1 indicated the equal preference between $i$ and $j$. A value of 9 indicated that the preference for criterion $i$ is nine times greater than the preference for criterion $j$. With this comparison method, if criterion $i$ is, say, 5 times less preferred to $j$, then the judges would have to assign a reciprocal value of $1 / 5$. Such a pair-wise comparison results in an ( $n \mathrm{X} n$ ) matrix. In our study, the judges found the above factor scale confusing, and therefore, we were forced to first use a linear and simpler factor scale of -10 to +10 . On this scale, the value 0 indicates equal importance between two criteria while a preference of 10 indicates one factor is 10 times more important than the other. This scale was chosen to make it easier for judges to rank factors the same below and above the diagonal 
without having to invert the value. After we obtained the initial comparison, we retained only the positive numbers and re-scaled the factor scale of $0-10$ to $1-11$. The rescaling does not affect the original order of preference. This operation left all the diagonal cells with number 1 (meaning equal preference between each $i$ and $j$ ). Also, it left each cell with a negative value on the original comparison empty. For each empty cell $(i, j)$, we used the reciprocal value of its diagonal cell $(j, i)$. The end result of the above operation is a pair-wise matrix with appropriate properties necessary for further matrixmanipulation as explained below. For instance, if we had kept the original linear factor scale, mathematically it would have been impossible to keep the order of the hierarchical process. When we added the values of the cells of each column, the positive and negative numbers would have canceled each other out fully or partially.

Each judge performed ranking independently. Personal judgment by experts would result into inconsistency of comparison. A mathematical test was conducted to check the consistency, which is explained in the next section. A consistency ratio of 0.1 was considered as acceptable upper limit (Saaty and Vargas, 2001., Krajnc and Glavic, 2004). The ranks given by eight judges were combined by finding the average of each rank in a cell (Table 3 ).

In table 3 the factor "social" represents social cultural and institutional factors; "technical" stands for technical feasibility of a technology; "environmental" stands for environmental and natural resource protection; and, "affordability" means economic and financial aspects of the technology. 
Table 3: Pair-wise matrix of sustainability factors

\begin{tabular}{|l|r|r|r|r|r|}
\hline Factors & Social & Affordability & \multicolumn{1}{|c|}{ Technical } & Environmental \\
\hline & \multicolumn{7}{|c|}{ The Average Values of Rankings of 8 Judges } \\
\hline Social & 1.000 & 5.146 & 3.431 & 4.156 \\
\hline Affordability & 0.194 & 1.000 & 3.125 & 4.500 \\
\hline Technical & 0.291 & 0.242 & 1.000 & 3.375 & \\
\hline Environmental & 0.241 & 0.182 & 0.229 & 1.000 & \\
\hline Sum & $\mathbf{1 . 7 2 6}$ & $\mathbf{6 . 5 7 0}$ & $\mathbf{7 . 7 8 4}$ & $\mathbf{1 3 . 0 3 1}$ & \\
\hline & \multicolumn{7}{|c|}{ Factor Ratios } & & Weights \\
\hline Social & $0.579^{\mathrm{a}}$ & 0.783 & 0.441 & 0.319 & 0.531 \\
\hline Affordability & 0.113 & 0.152 & 0.401 & 0.345 & 0.253 \\
\hline Technical & 0.169 & 0.037 & 0.128 & 0.259 & 0.148 \\
\hline Environmental & 0.139 & 0.028 & 0.029 & 0.077 & 0.068 \\
\hline
\end{tabular}

${ }^{1}$ Factor ratio of each cell $(i, j)$ is calculated by dividing the "Sum" value of column $j$ into the "average value of ranking" in cell $(i, j)$. For instance, the factor value of Social-Affordability pair is calculated as $5.146 / 6.570=0.783$.

${ }^{2}$ The weight for each row $i$ is the average of all four factor ratios of that row.

Consistency of the general matrix was also checked and the average vector values from general matrix provided the weight we needed to calculate sustainability sub-index $\left(I_{S}\right)$. The average vectors value also provided the rank of criteria where the higher the value, the more important is the factor or criterion.

\subsubsection{Checking consistency of the pair-wise matrix}

Consistency of the matrix was determined by calculating a consistency ratio (CR) obtained from Consistency Index (CI) that expressed the deviation from consistency. Following Coyle (2004), the Consistency Index for a matrix was obtained from the following formula:

$$
C I=\frac{\lambda_{\max }-n}{n-1}
$$


Where $n$ is the number of criteria in the comparison matrix, and $\lambda_{\max }$ is an estimate of the Eigen value of the comparison matrix. If the comparison matrix is not perfectly consistent, $\lambda_{\max }$ will be greater than the order of the matrix, $n$ (Saaty and Vargas, 2001). In order to compute $\lambda_{\max }$, first the Eigenvector needed to obtain by multiplying together the entries in each row of the matrix and then taking the $n^{\text {th }}$ root of that product. The $n^{\text {th }}$ roots of all four rows were summed and that sum was used to normalize the eigenvector elements to add to 1.00 . The new eigenvector was obtained by multiplying on the matrix of judgments by the eigenvector. The above computation yielded a $C I$ value of 0.12 .

The $C I$ was then compared to the corresponding random consistency indices $(R I)$ described by Saaty and Vargas (2001) in which the upper row is the order of the random matrix, and the lower is the corresponding index of consistency for random judgments (see table 4).

Table 4: Average random consistency index $(R I)$

\begin{tabular}{|c|c|c|c|c|c|c|c|c|c|c|}
\hline $\mathrm{N}$ & 1 & 2 & 3 & 4 & 5 & 6 & 7 & 8 & 9 & 10 \\
\hline $\mathrm{RI}$ & 0 & 0 & .52 & .89 & 1.11 & 1.25 & 1.35 & 1.40 & 1.45 & 1.49 \\
\hline
\end{tabular}

Saaty and Vargas (2001)

The consistency ratio was then calculated as follows;

$$
C R=\frac{C I}{R I}=\frac{0.12}{0.89}=0.13
$$

A comparison matrix from judges was accepted if consistency ratio of the pair-wise was around 0.10 (i.e., $90 \%$ consistent or $10 \%$ inconsistent). The above CR value of 0.13 was considered as acceptable for this study. 


\subsubsection{Normalization of indicators}

Since the sustainability indicators are expressed in different units, they were normalized using formula 1 and 2 depending on whether indicator has positive or negative impact on sustainable development respectively.

$$
I_{N, i j}^{+}=\frac{I_{A, j, i}^{+}-I_{\min , j, i}^{+}}{I_{\max , j, i}^{+}-I_{\min , j, i}^{+}}
$$

$$
I_{N, i j}^{-}=1-\frac{I_{A, j, i}^{-}-I_{\min , j, i}^{-}}{I_{\max , j, i}^{-}-I_{\min , j, i}^{-}}
$$

Where $I_{N, j, i}^{+}$is the normalized indicator $i$ (with positive impact) of group $j, I_{N, j, i}^{-}$is the normalized indicators $i$ (with negative impact) of group $j ; I_{\min , j, i}^{+}$is a minimum value of a given indicator, $I_{\max , j, i}^{+}$is a maximum value of the indicator, and $I_{A, j, i}^{+}$and $I_{A, j, i}^{-}$were the measured values of given indicators.

\subsubsection{Calculation of composite sustainable development index}

Using normalized values of each indicator, the sub-group indicators $\left(I_{s}\right)$ and the weight of criteria, the sustainability sub-index $\left(I_{S}\right)$ and the composite sustainable development index $\left(I_{C S D}\right)$ were computed using the following formula;

$$
I_{S, j}=\sum_{i}^{M} W_{j, i} \cdot I_{S, j, i} \text { for each } j=1 \ldots 5
$$

$$
I_{I C D}=\sum_{j}^{N} W_{j} \cdot I_{S, j}
$$

Where

$$
\sum_{i}^{M} W_{j, i}=1 \text { and } \sum_{j}^{N} W_{j}=1
$$


The composite sustainability index (5) was computed for each technology, in each village, the value of which was used to rank technologies from most sustainable to the least. The higher the value of $\left(I_{C S D}\right)$ the more sustainable is the particular technology in a study area. This process was accomplished using Excel. 


\subsection{RESULTS AND DISCUSION}

\subsection{Introduction}

This chapter presents observations and interpretation of the data that were collected using the above described methodology. The section summarizes results according to the objectives of the study. Divided into sections, the chapter describes existing sanitation situation in the area, explores local characteristics of the area that influence adoption of a given sanitation method and lastly describes the ranking of sanitation technologies on the basis of the composite sustainable development index. The chapter begins with description of the sample characteristics including demographics, education level and social economic characteristics of sampled household.

\subsection{Sample Characteristics}

\subsubsection{Demographics}

A total of 500 households were visited in five villages, with approximately 100 households in each village. The age of the sample respondents ranged between 18 to 91 years, with a mean age of 44 years. The numbers of male and female were almost equally distributed, $54 \%$ men and $46 \%$ female. In each village however, the number of males and females varied depending on household head that was available at home during the survey. During household surveys, wives preferred that their husbands be interviewed while in other places women would not allow their house be skipped because the husband was not at home. Fig. 1 shows gender distribution in each village visited. 


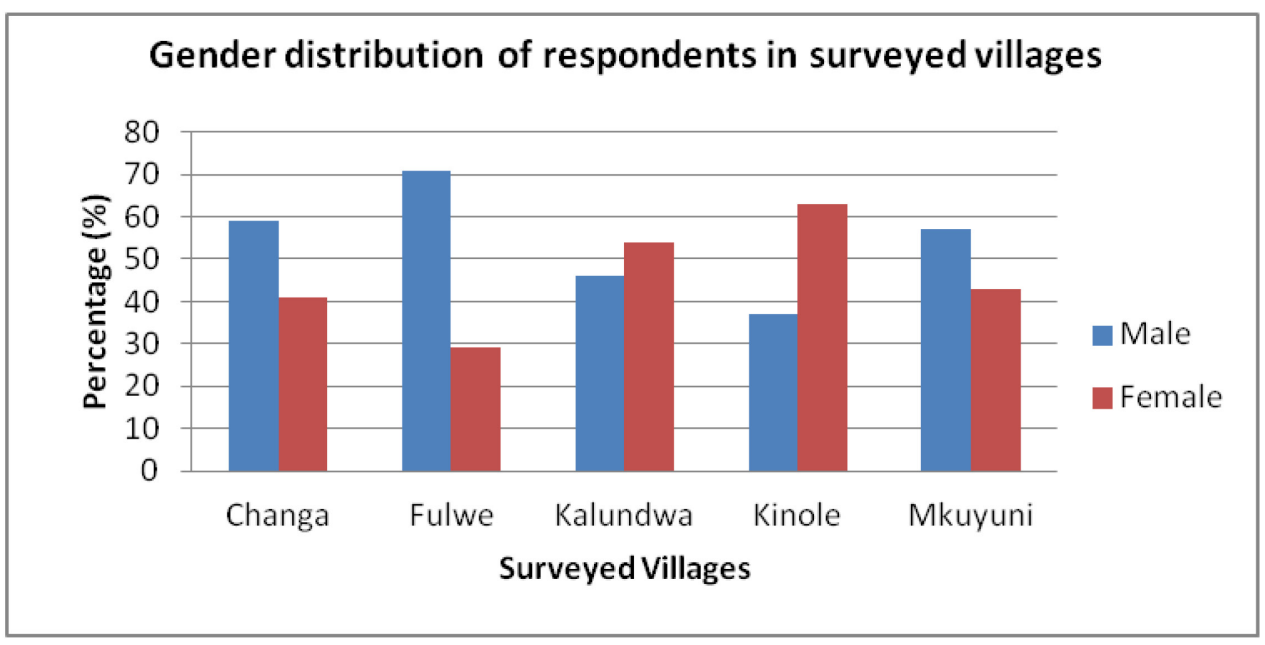

Figure 1: Gender distribution in sampled villages

Fulwe village had the fewest female participants in the study, because it was easy to find fathers at home. In Kinole village where women made the majority of people interviewed for during household visit, most of men were away on daily activities until late in the evening. The survey was held between 2:00 pm and 5:00 pm

A majority (88\%) of the respondents were from Luguru tribe. Of the five villages, Fulwe had large number of non-Luguru tribe; about $48 \%$ of all respondents in the village were non-Luguru. In other villages Luguru tribe made a largest proportion with $95 \%$ in Changa village, $99 \%$ in Kalundwa, 98\% in Kinole and 96\% in Mkuyuni village.

In all villages Muslims constituted the largest portion of the sample households interviewed. Approximately 93\% were Muslim while the remaining 7\% were Christians. The proportion of Muslim in the village is higher than the national average of $62 \%$ Christians and 35\% Muslims (The U.S Bureau of Democracy, Human Rights, and Labor, 2009). The government of Tanzania however, does not collect religious identification in its national census or household budget surveys. 


\subsubsection{Education level}

Of the residents interviewed, only $0.4 \%$ had college education and $4 \%$ had secondary school education. A majority of residents (69\%) had primary school education while $27 \%$ had never gone to school or reached standard four (see Fig. 2).

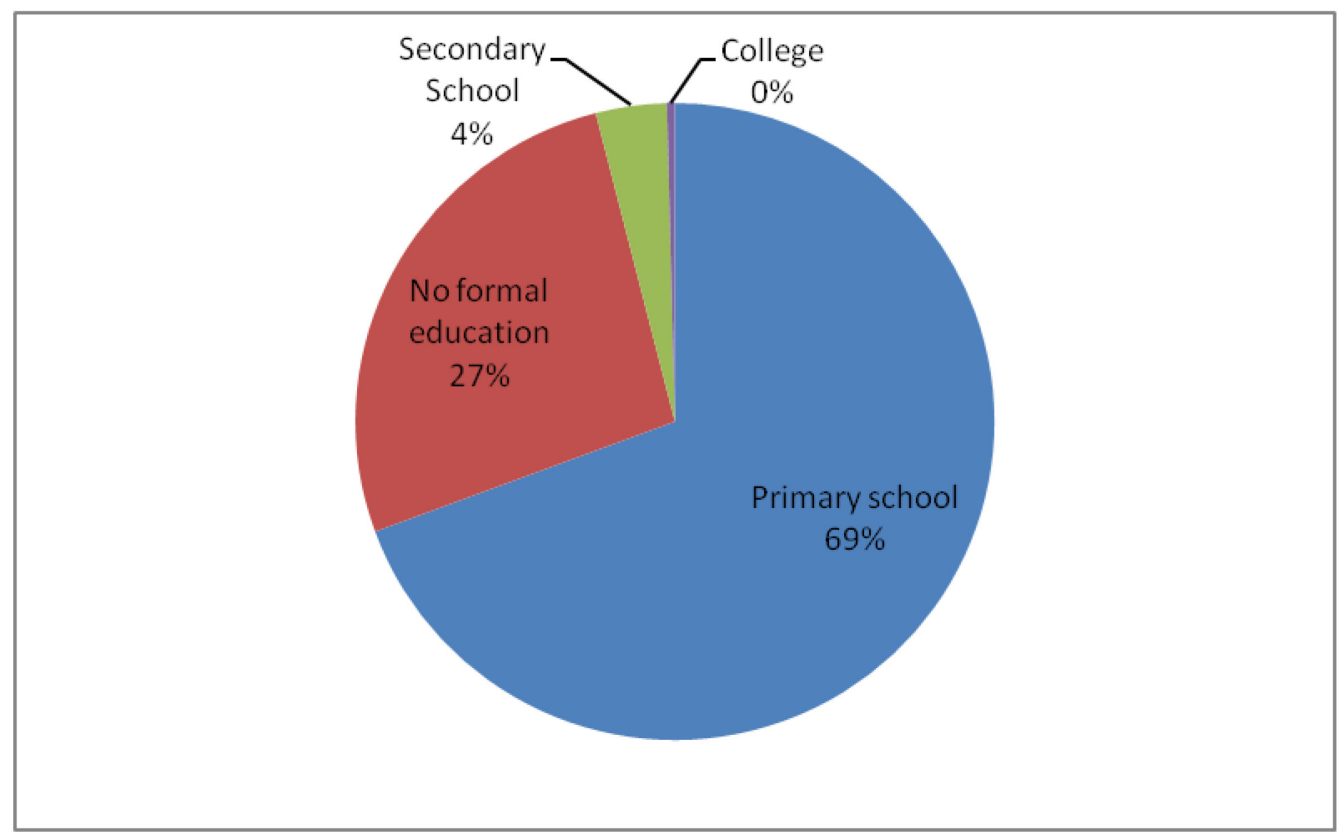

Figure 2: Distribution of education level of participants in surveyed villages

Education level varied across villages. Kinole had a large number of respondents who had never gone to school $(36 \%, \mathrm{~N}=100)$. Also, Fulwe village had large number of respondents who had secondary school education compared to other villages. The difference in education among villages was statistically significant. A Chi-square test of the relationship between level of education and villages produced $\chi_{12}^{2}=43.55$, which is significant at $p<0.05$. The same villages - Fulwe and Kinole village - also had higher gender variation. In this study, men reported higher level of education than women; villages where men were the majority of respondents (like Fulwe), had higher education 
level than villages in which a majority of respondents were women, like Kinole. Thus, the sample may have been biased toward men with higher education.

\subsubsection{Socioeconomic characteristics}

In the Focus Group Discussions (FGS) participants defined social economic status of a family on the basis of the quality of house one family lives in. Extremely poor families were those that lived in a house constructed with poles with mud walls, mud floors and thatch roof. A well-off family was described as the one that live in a house constructed with block (cement sand bricks) wall, cement floor/tiles, and iron sheet roof. The categorization as extremely poor, poor, least poor and well off is given in table 5 .

Table 5: Socioeconomic status on basis of household characteristics

\begin{tabular}{|c|c|c|c|c|}
\hline \multirow{2}{*}{$\begin{array}{l}\text { Household } \\
\text { Category }\end{array}$} & \multicolumn{3}{|c|}{ Criteria } & \multirow{2}{*}{$\begin{array}{c}\text { Percent of } \\
\text { Households }\end{array}$} \\
\hline & Wall & Roof & $\begin{array}{c}\text { Floor } \\
\text { material }\end{array}$ & \\
\hline \multirow[t]{3}{*}{ Extremely poor } & Poles and mud & Thatch (Grass) & Mud & \multirow[t]{3}{*}{25} \\
\hline & Poles and mud & Iron sheet & Mud & \\
\hline & Sun-Dirtied bricks & Thatch (Grass) & Mud & \\
\hline \multirow[t]{2}{*}{ Poor } & Sun-Dirtied bricks & Irons sheets & Mud & \multirow[t]{2}{*}{25} \\
\hline & Baked bricks & Thatch (Grass) & Mud & \\
\hline \multirow[t]{2}{*}{ Least poor } & Baked bricks & Iron sheets & Mud & \multirow[t]{2}{*}{27} \\
\hline & Sun-Dirtied bricks & Irons sheets & Cement & \\
\hline \multirow[t]{2}{*}{ Well off } & Baked bricks & Iron sheets & Cement & \multirow[t]{2}{*}{23} \\
\hline & Cement bricks & Iron sheet & $\begin{array}{l}\text { Cement/ } \\
\text { Tiles }\end{array}$ & \\
\hline
\end{tabular}

Figure 3 presents the distribution of households by the above socioeconomic categories. On average, an equal proportion of sample respondents $(25 \%)$ belonged to extremely poor category and poor category each. The least poor respondents were slightly in large number with about $27 \%$ while the rest belonged to well off category with $23 \%$. 


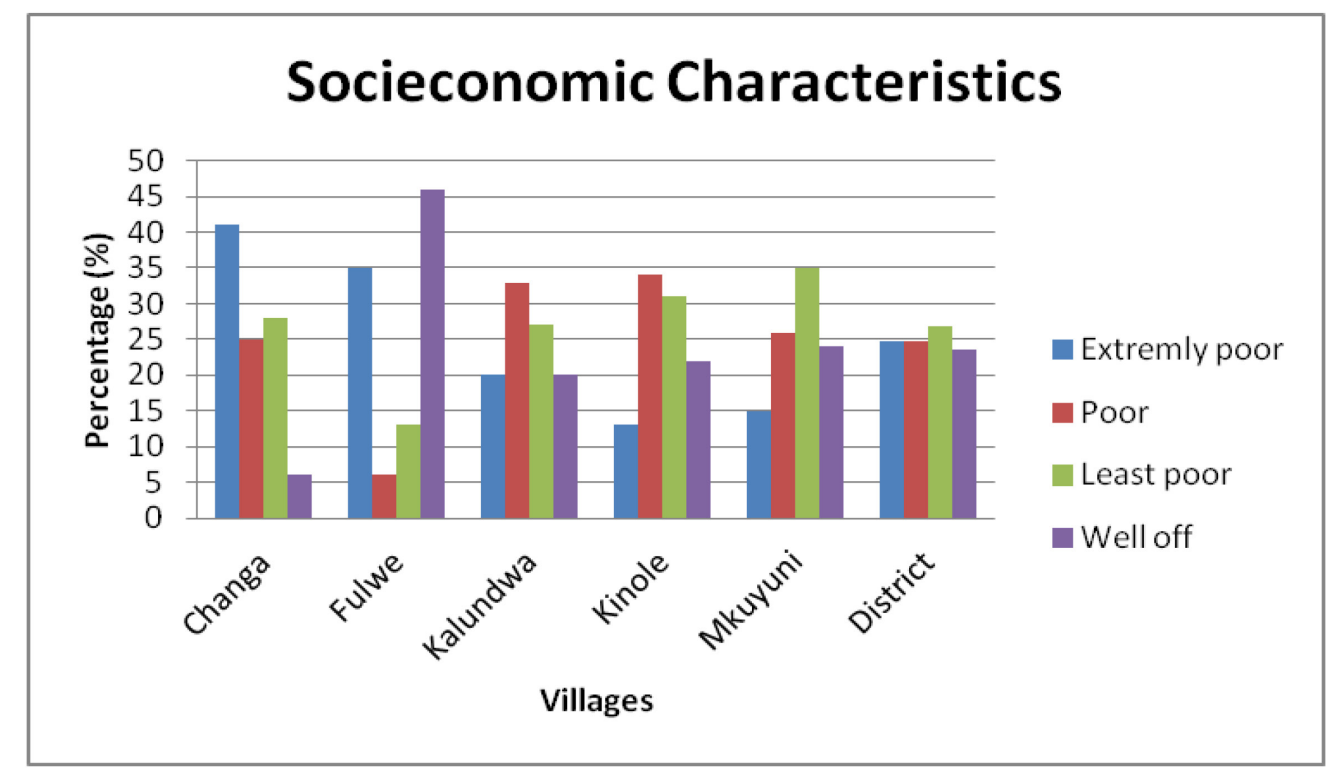

Figure 3: Distribution of socioeconomic characteristics

Across the villages, the proportions of groups differed. Fulwe village had the greatest number of well off respondents $(46 \%)$, because a majority of the surveyed houses were constructed with baked bricks and cement floor, a characteristic of the well off group. About $62 \%$ of the households visited in Fulwe village were constructed with baked bricks and $48 \%$ had cement floor. The proportion with cement floor was the highest among all villages. According to the residents, living in a household with cement floor is a sign of a wealthy person; thus the survey interviewed more wealthy individuals in Fulwe than in other villages.

Changa and Fulwe villages show large proportion of extremely poor group for these villages had higher number of respondents living in poor houses, houses constructed with poles and mud wall, and mud floor. About $36 \%$ of respondents in both Changa and Fulwe lived in houses constructed with poles and mud. Changa village has 
the large proportion of respondents who live in a house with mud floor $(89 \%)$ followed by Fulwe $48 \%$.

My study aimed at studying rural characteristics, and therefore, the data collection had to take place in remote areas than around village centers. Reaching more remote houses was only possible in Fulwe and Changa villages where houses were easily accessible by roads. The rest of the villages were at the mountain ridges and valleys which made it hard to reach large number of individuals living away from village centers given limited amount of time. In mountainous villages, data were collected from households that were around the village centers where a large number of houses were constructed with sun-dried bricks/baked brick and roofed with iron sheet, a characteristic of least poor and well off households.

\subsubsection{Household Income and Occupation}

Individuals in rural Morogoro earn approximately Tanzanian Shillings (TZS) 250 per day an income derived mainly through farming (MDC, 2011). In surveyed villages $90 \%$ of all the people were farmers cultivating a variety of crops mainly maize, rice and fruits for subsidence. While maize and rice were common in all villages, other crops were cultivated in large quantity in one village than the other. Villagers in Fulwe cultivate sunflowers from which oil was extracted while Kalundwa and Kinole villagers cultivate spices to supplement income from rice, maize and fruits (i.e. banana, pineapples and oranges).

Most of interviewees reported to own cell phones (60\%) and very few had television set $(9 \%)$ or motorcycle $(5 \%)$. An average value of these assets was estimated at 
TZS 35,000, TZS 150,000 and TZS 1,200,000 for mobile phone, Television set and motorcycle, respectively. Lack of electricity makes ownership of televisions difficult. Most of the people with motorcycles used it as a source of income because the motorcycle is used as means of transport. Motorcycles are common in all villages, though the majority were seen at Fulwe village (10\%) while in Kalundwa and Kinole, 5\% reported to have one.

\subsection{Sanitation status}

Sanitation status in the surveyed villages is poor; toilets are constructed with temporary materials and lack roofing and door which compromise privacy. Lack of roof cover exposes floor and logs to rains, leading to frequent pit collapse. Other reasons that contribute to pit collapse may include lack of pit lining and poor location of toilets. Toilets are located in a sloppy land as such they are vulnerable to speedy runoff and soil/land slides.

In this survey, about $96 \%$ of households had toilets and $4 \%$ had none. Of those who had toilets only $9.4 \%$ had improved toilets, such as the improved floor toilets $(5 \%)$, VIP latrines $(2 \%)$, and pour flush $(2 \%)$. The proportion of household with improved toilets corresponds to the national estimates of improved sanitation coverage in rural areas of $9 \%$ as reported by the National Bureau of Statistics (NBS) in the Demographic and Health Survey report of 2010 . However, coverage of $9.4 \%$ is very low compared to the 2010 national target of improved sanitation from 23\% to 35\% the 2015 (MoFEA, 2010). Thus the coverage of sanitation in these villages is below national estimates. 
There is also a significant variation across villages in the proportions of households without any form of latrines, those with unimproved, and those with improved toilets. A Chi-square test of the relationship between toilet coverage and villages yields $\chi_{8}^{2}=51.65$ which is statistically significant at the 0.05 level. Fulwe village had the highest number of households with improved sanitation $(25 \%)$ of all villages whereas Kalundwa village had the highest number of households without toilets 9\% (see Fig. 4).

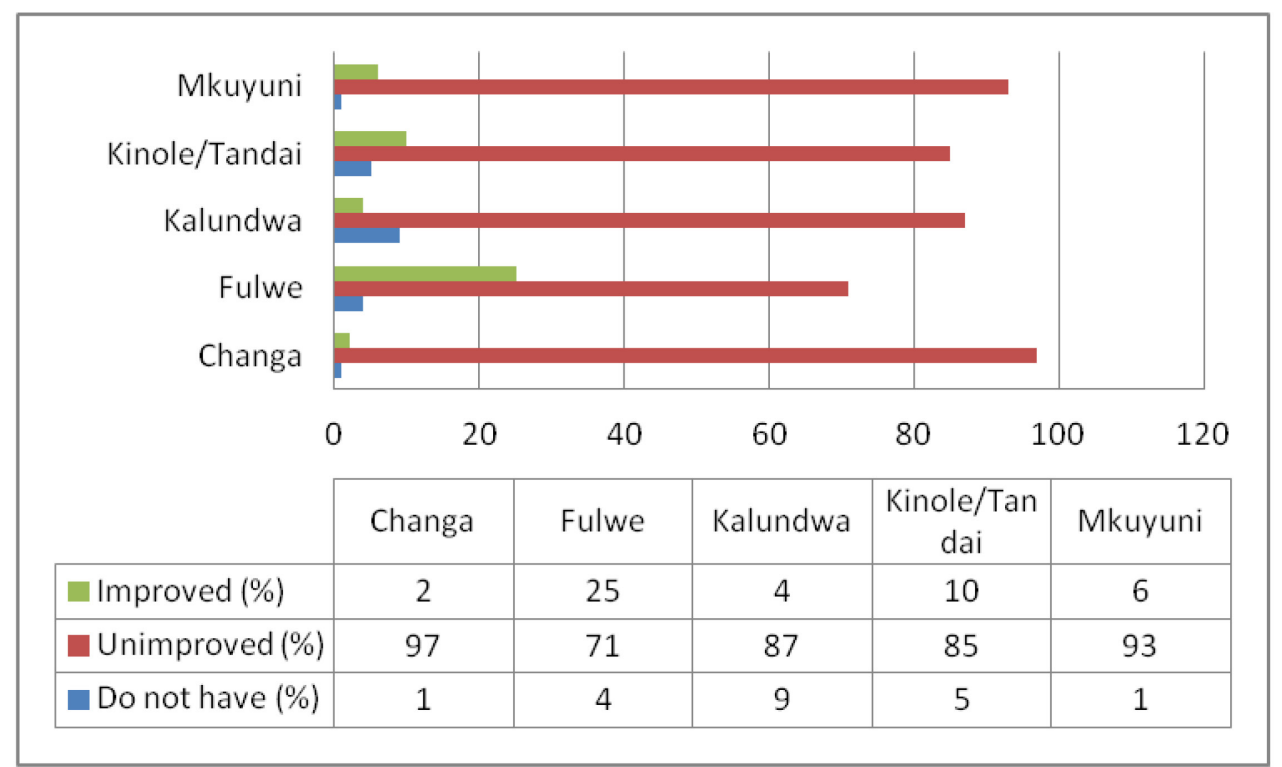

Figure 4: Sanitation coverage in sampled villages

Households that do not have toilets either depend on neighbors or have two families sharing the toilet. In the sample villages, especially Kalundwa and Kinole, fathers distribute plots to their children who when become independent (get married), build a house on their plots near their father's house. Thus, while they make their own food (become independent household), they still depend on their parents' toilets. During interview with those independent young man, their response to question why they did not 
have toilets differed from their parents. Parents acknowledged that their sons use their toilets on a temporary basis. The sons however, responded that they had one before, but it collapsed during the rainy season. Other households without toilets could have just moved to a new house that lacked toilet. This means that one can start living in a house before digging a toilet. However, some did agree that a toilet had to be constructed first, which was consistent with the observations made in Kikuyu in Kenya (Jackson, 2004).

In some families plots are small and the land is mountainous to have each and every son surrounding their father to have their own toilets. However, this behavior was seen to contribute to having poor type and poor maintenance. Those who have just returned to the village from town also contribute to the number of households without toilets for most of them use their neighbor's toilet before they construct their own.

\subsubsection{Socioeconomic status and use of improved sanitation}

In the sample villages most of improved toilets are seen in families with higher socioeconomic status. The analysis of data shows that improved sanitation technologies are common among well off families $(57.4 \%, \mathrm{~N}=47)$ followed by least poor families $19 \%$, the difference which is statistically significant. A chi-square test of the relationship between socioeconomic status of the family and type of sanitation technology used gives $\chi_{6}^{2}=35.8(p<0.05)$, which is statistically significant, suggesting strong association between socioeconomic status and type of sanitation technology.

Having a cement floor in the house is a sign of wealth. The households with a cement floor are most likely to use improved sanitation technologies than households with a mud floor. A Chi-square test of the relationship between households with cement 
floor and type of sanitation technology provided $\chi_{2}^{2}=24.2$ which is again statistically significant at the 0.05 level, suggesting a strong relationship between cement floors in the house and improved sanitation technologies.

\subsubsection{Education level and use of improved sanitation}

Importance of proper sanitation is taught at least from primary schools level. Household heads who missed the opportunity to attend at least primary school were the majority whom their households had no toilets. The analysis of data shows that $55 \%$ of households that were found to lack toilets did not have any formal education. About $45 \%$ of those did not have toilets however had primary school education level; none of the secondary school headed family was found to have a toilet in or near the house. Improved toilets were also found in some households headed with individual who had not gone to school but the proportion was small $(7.5 \%)$ where for those with secondary education $28 \%$ had improved toilets. A Chi-square test of this relationship between level of education and type of sanitation technology provide $\chi_{6}^{2}=16.4$ which is statistically significant, suggesting that education level does have an effect on the adoption of improved sanitation technology.

\subsubsection{Problems associated with existing sanitation technologies}

Households with unimproved toilets have bathroom and toilet sharing the same structure i.e. a toilet and bathroom share same entrance and room. Only those with improved types had a bathroom separated from toilet room. Yet in both types of toilets (i.e., improved and unimproved toilets), grey water from bathroom and from a place used for anal cleansing are drained outside. Anal cleansing is performed aside the drop hole to 
avoid wetting a floor/slab or collapsing pit. As a result, grey water is seen scattered outside yet only few reported it as nuisance (37\%). The only nuisances they see is odor (reported by $84 \%$ ), and flies and cockroaches (reported by $85 \%$ of respondents).

Nuisance is reported mostly by individuals who use unimproved sanitation technologies. For instance, of the 437 individuals who reported bad odor as a problem, $91 \%$ used unimproved sanitation. Bad odor was also reported by $8 \%$ of individuals who use improved sanitation technology. Bad odor from improved toilets may be the result of the fact that a majority use improved floor toilets which lack a vent pipe or water seal that could control odor and flies. Individuals who use those improved technologies with a vent pipe and water seal nevertheless, still report odor and flies problem. About $2 \%$ of individual reported bad odor and smell using improved technology. These problems may be caused by construction problem because in some places/household vent pipes were bent to avoid making a hole on a roof. The vent pipe works better when it is straight (Mara, 1985a). Some pour flush toilets have a squatting pan that are without a water seal. During the survey these types of technologies were grouped under VIP latrine for they had a vent pipe although requires water for flushing.

\subsubsection{Sanitation and diseases occurrence}

In a list of top ten diseases that lead to morbidity in Morogoro district, diarrhea is number 5 across all ages (MDC, 2011). In surveyed villages, incidence of diarrhea in all age groups varied, from relatively a high incidence rate in Changa of 37/1000 to a low incidence rate in Fulwe of 3.4/1000. These incidence rates were based on the 2011 population numbers obtained from the 2011 district social economic profile (MDC, 2011) 
and the number of cases occurred during a period from January to March 2011 as reported by the Department of Health under the infectious disease surveillance and response system. Although further studies are necessary, the above numbers provided early indications that low diarrhea incidence occurred in villages with high coverage of improved sanitation than in villages with low coverage of improved sanitation (see fig. 5). For instance, Fulwe that had higher coverage of improved sanitation technology had lower incidence rates of diarrhea disease. Meanwhile Changa village with very low coverage of improved sanitation had relatively higher incidences of diarrhea. This observation may support the importance of improved sanitation on disease reduction.

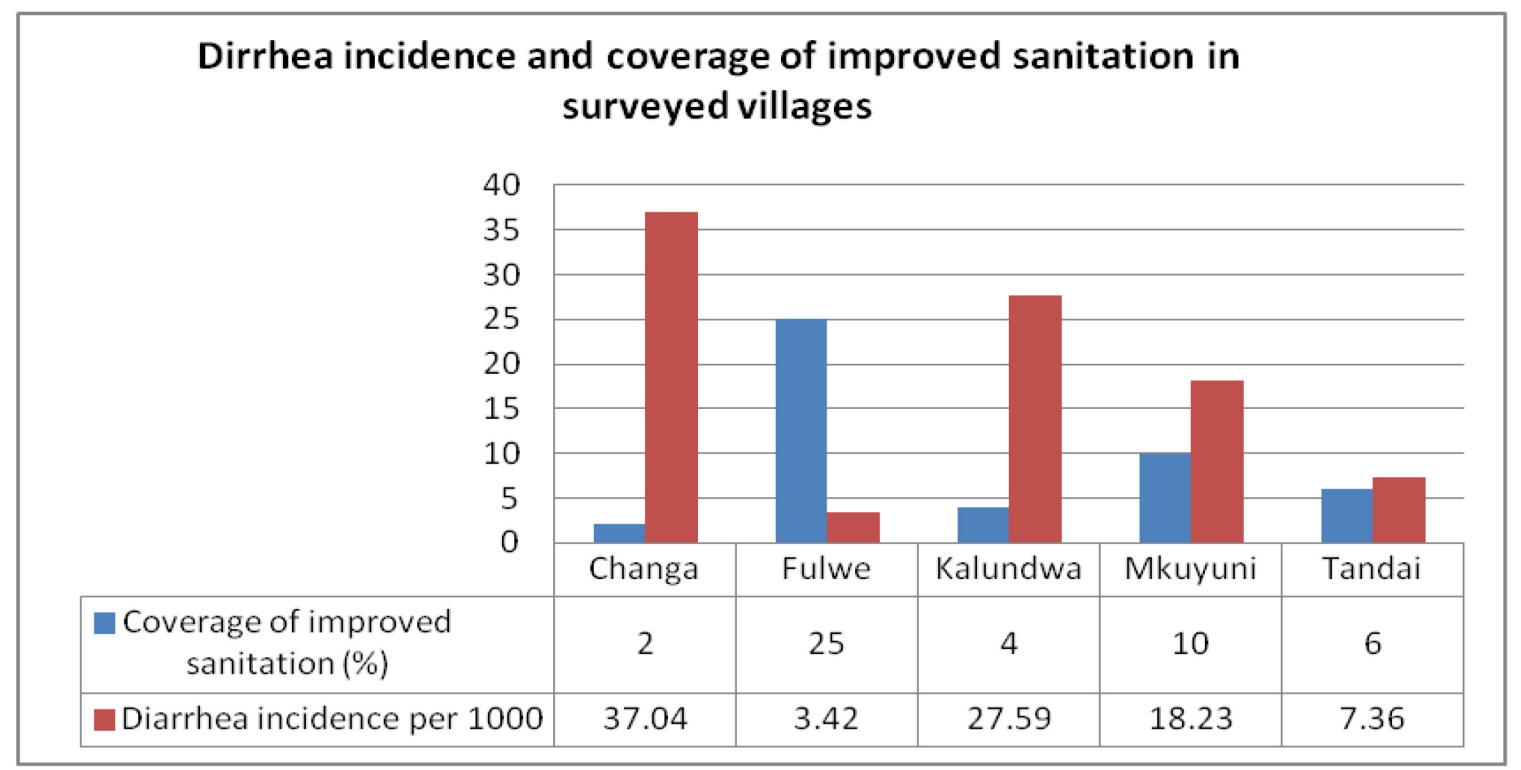

Figure 5: Diarrhea incidence rates and coverage of improved sanitation (Source of disease incidence data - Department of Health Morogoro District, Tanzania,)

Figure 6 presents the estimated exponential inverse relationship between the incidence rate and the percent sanitation coverage. The $R^{2}$ value of 0.71 indicates a strong influence of sanitation coverage on diarrhea incidence rate. 


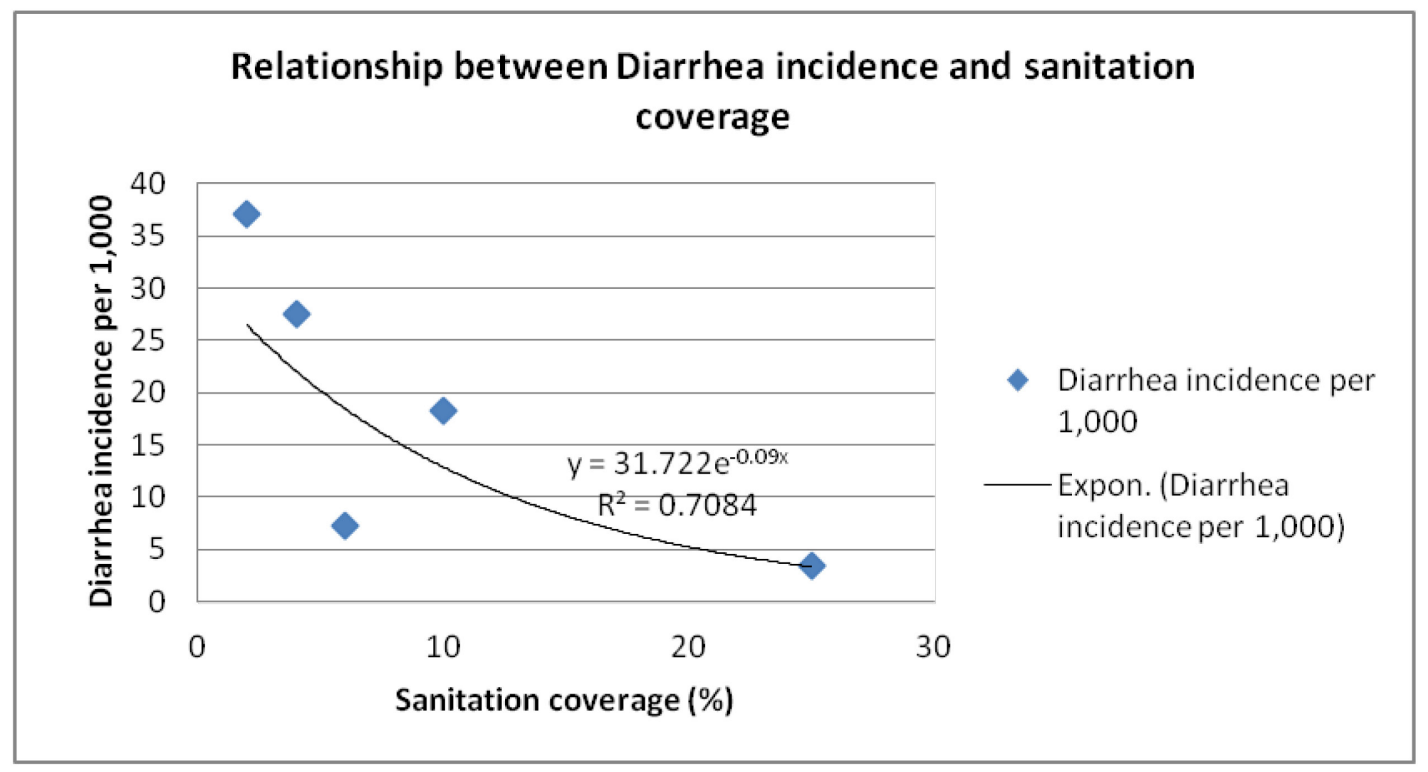

Figure 6: Diarrhea incidence and coverage of improved sanitation in study villages.

\subsection{Access to safe water supply}

Seventy four percent of the sample households have access to safe drinking water, which is higher than the level estimated by the district council, 61\% (MDC, 2011). This proportion also exceeds the national target of $65 \%$ of rural residents having access to safe and clean water by 2015 (MoFEA, 2010). However, there is variation in access to safe drinking water between study villages. Access to water supply was $100 \%$ in Kinole/Tandai village while access was as low as $14 \%$ in Kalundwa village (see fig. 7).

Common sources that supply water to the villages included taps that supply water from borehole or other sources though gravity system. Other sources were hand pumps fitted on shallow wells which were protected by 400m zone from nearest households. Fig. 8 shows distribution of water sources in each village by type. 


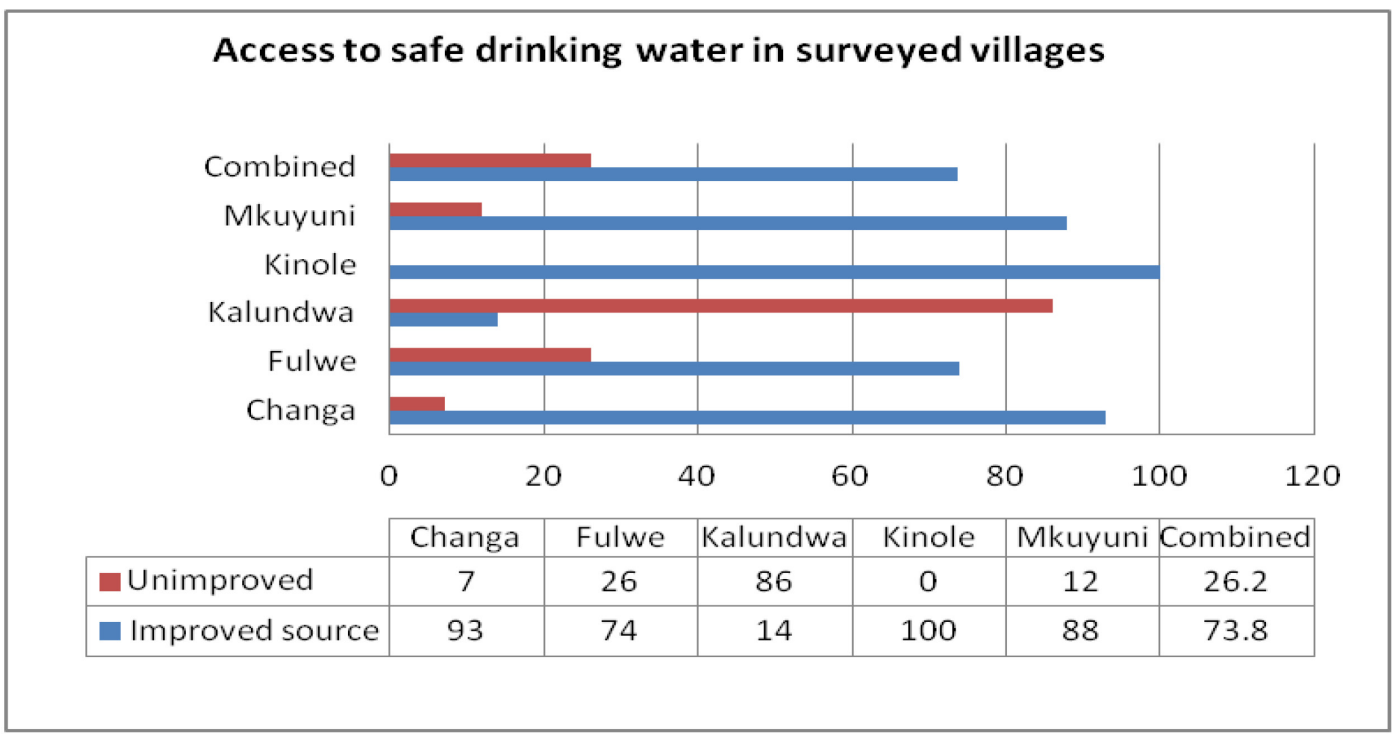

Figure 7: Access to safe drinking water in surveyed villages

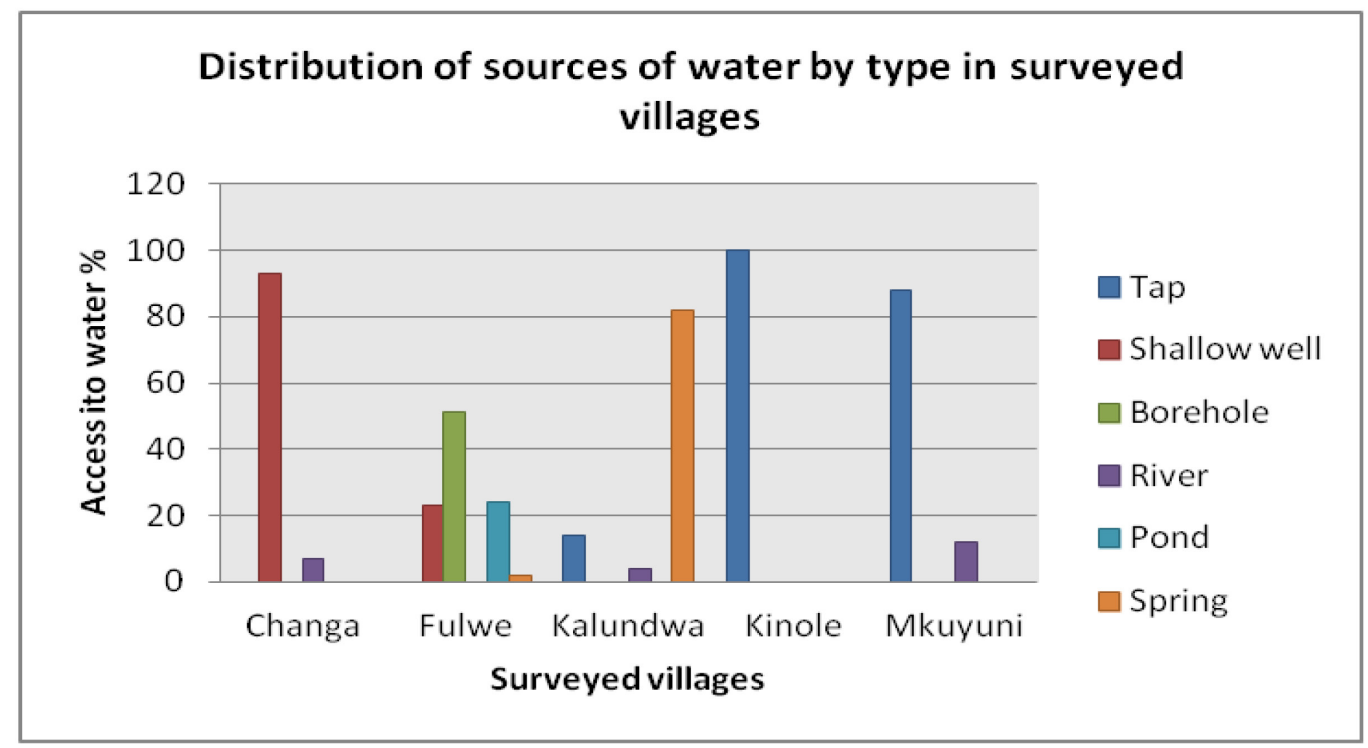

Figure 8: Distribution of sources of safe drinking water in surveyed villages

Of the five villages, Kinole and Mkuyuni have sources that are reliable through out the year; the rest of villages experience water shortage in dry season (Changa, Fulwe and kalundwa). Households that obtain water from pond (e.g., in Fulwe village) and rivers (e.g., in Kalundwa) experiences water shortage during rainy season for the sources become murkier than usual when it rains. 


\subsubsection{Water supply and health}

Fulwe and Kalundwa villages have no access to adequate supply of water to meet daily needs and thus hygiene cannot be assured. Fulwe residents are supplied with water from borehole and shallow well, which are more than 400 meters away and $73 \%$ of household spend more than half an hour to obtain water from these sources. The sources do not provide water throughout the year. During the dry season wells supply no water and during the rainy season ponds are murkier to fetch water from. During water scarcity villagers resort to either neighboring village (86\%) and/or buy from venders who use vehicles $(18 \%)$. The situation is even worse in Kalundwa village where residents obtain water from unprotected spring which dries in summer and fall; during these seasons residents have to resort to the river.

The residents of Changa village access safe drinking water at the basic level, a level that still does not guarantee hygiene practices. A majority of villagers, i.e., 93\%, obtain water from shallow wells and remaining 7\% obtain from river. Even though 54\% of the households spend less than half an hour to fetch water from these sources, because they walk 400 meter to reach the source, the average quantity collected is unlikely to exceed 20 liters per capita per day. Such low quantity of daily water use makes hygiene practice difficult increasing the likelihood of adverse health condition.

The two remaining villages of Mkuyuni and Kinole/Tanda access water at intermediate level, the level that corresponds to low levels of health concern. Residents may collect in average quantity of about 50 liters per capita per day and thus are able to maintain proper hygiene. In these villages water service is delivered through one tap on 
plot or at a communal place within 100 meters, and residents spends less than 30 minutes in total collection time. In Mkuyuni, 96\% of residents reported to have spent less than 30 minutes in total collection time, and $97 \%$ of the respondents said the sources were able to supply water throughout the year. The situation is similar in Kinole/Tandai village, in which all households visited receive water supply though a tap at the plot or at a communal place, with furthest household located within 100 meter, and the service is available all year long.

\subsubsection{Water supply and diseases incidences}

Incidence of diarrhea is expected to be lower in villages with adequate supply of water as compared to those with limited access to safe water supply. The data obtained in this surveyed is insufficient to support the relationship between diarrhea disease incidence and access to water. For instance Mkuyuni and Kinole/Tandai villages have higher access to water (intermediate level), and the incidence of diarhoea is lower. However, Changa village has basic access to water yet its diarrhea incidence is higher than villages with limited access, Fulwe and Kalundwa (see Fig. 9). Therefore, we fail to

find a clearance evidence for support for the association between diarrheas incidence and access to basic water supply in the study villages. 


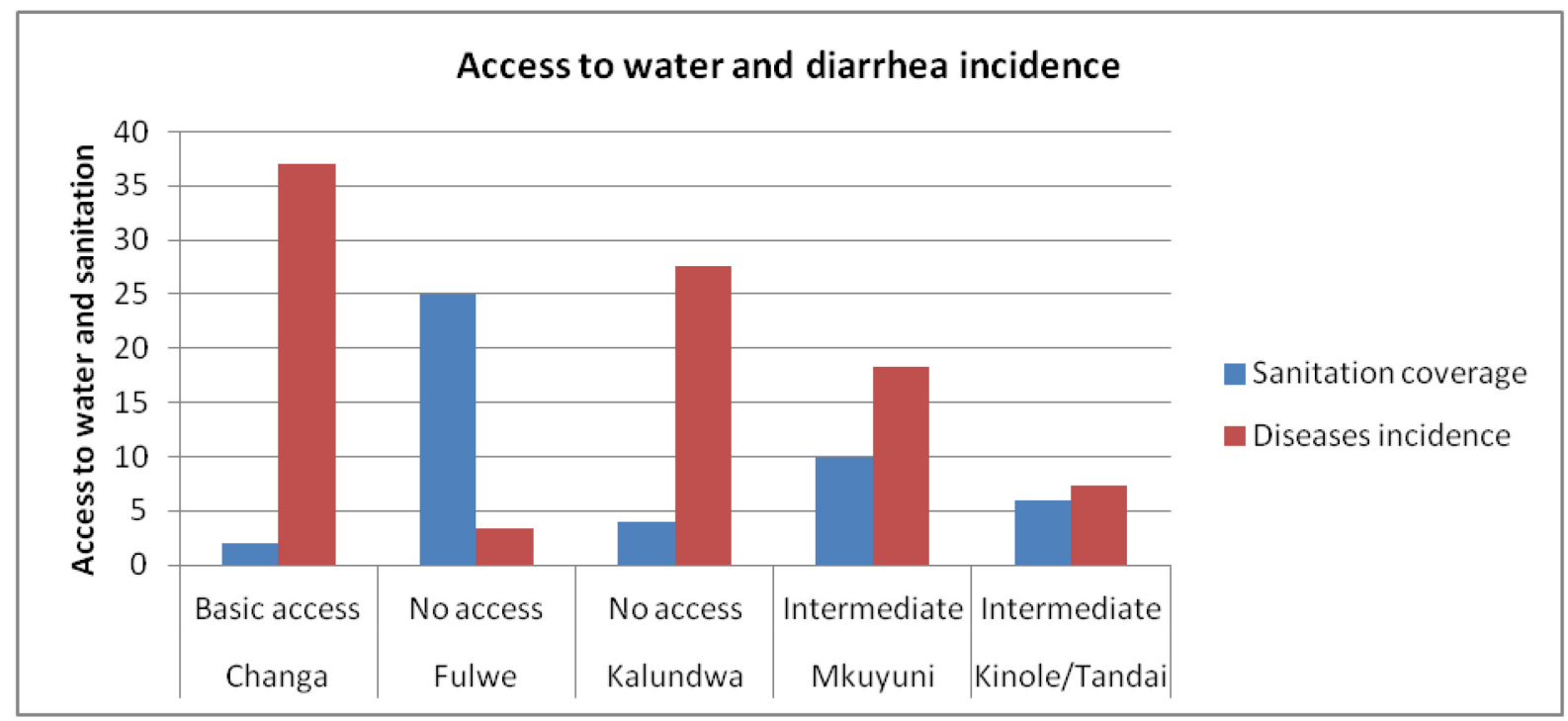

Figure 9: Access to safe drinking water and diarrhea incidence rates

\subsubsection{Hygiene practices}

Hygiene practices were assessed by observing whether or not a tippy tap was available and if there were signs of it being used (signs like wet floor). Tippy taps were not seen in any of the household visited except there were water containers in toilets that were used to store water for anal cleansing and washing hands after cleansing. There is a greater feeling that the way they wash their hands is enough; having a tippy tap outside a toiled for washing their hands seems a double work. This observation calls for hygiene education in sample villages. Further study is necessary for assessing the efficacy and effectiveness of tippy tap as compared to the normal practices of using the same water for anal cleansing.

\subsection{Environmental characteristics}

Environmental condition of surveyed villages was assessed to identify type of rock, risk to flooding, water table level, type of soil and other environmental factors that 
affects strength of a toilet pits or local availability of material for construction of toilets. The aim is to ascertain feasibility of proposed new technologies.

Except Fulwe village which is at the foot or low land, the rest of villages are located high up the Uluguru mountain. Mkuyuni village is higher in elevation than Fulwe whereas Kinole is at the highest level compared to all villages. The soil type in Fulwe is reddish/brownish clay soil, and the water table is about 6 meter -30 meter deep. Other villages which are in mountainous area have soil type that contains a mixture of alluvium deposits clay, sand and gravel. The water table is as high as 5 meter -10 meter deep. Some residents in Mkuyuni A and Mkuyuni B find water while excavating pits which suggests a high water table. The rock is hard to excavate in Fulwe village and some parts of Mkuyuni and Changa villages. During excavating pit stones are found, and villagers hammer or end up excavating a shallow pit of about six feet or less. This depth is not adequate if compared to the Ministry of Health guidelines which recommend a pit depth of $12 \mathrm{ft}$ (MoHSW, 2010). Nevertheless, a pit depth of $6-9$ feet may be enough provided a 6 feet height is left above water table level (Mara, 1985).

Generally, the geological characteristic of the area is such that the soil is loose and collapses easily. A common complaint that the households has is that mice are a major cause of pit collapse in their villages. Mice destroy toilet pits by burrowing under lateral $\operatorname{logs}$ used to construct a floor/slab. Burrowing animals fall standing wall; for example, rabbits can fall a huge cliff along the ocean (Bird, 1994; Griggs, 1994).

Some parts of Fulwe and Changa village experience floods. For instance, the sub villages of Dindili and Nungu, both from Fulwe village, experienced flooding one year ago and two years ago, respectively. In 2009 flood hit Misala sub village before hitting 
Mkuyuni B the next year. All 20 respondents in Mkuyuni B still remember the flooding event while only $2 \%(\mathrm{~N}=20)$ of people in Misala could remember a flooding event. This may be due to the fact that the floods affected few in Misala, but also there is a tendency for people to forget hazards within short time.

Toilet pits are covered by logs derived from natural and exotic trees. The commonly used tree as source of logs/wood is Spyrostachys africana or Mcharaka in Swahili. Other trees used are Bridelia micrantha, known by indigenous people as Mwiza in Luguru or Mkarati in Swahili, Artocarpus heterophyllus called Mfenesi in Swahili and Cedrella odorata or Msederela. These are common trees in this area. All five villages have natural forests that rage in size between $2.12 \mathrm{KM}^{2}$ in Kalundwa to $3.95 \mathrm{KM}^{2}$ in Kinole/Tanda. The abundance of these trees however is not known since the inventory was yet to be established.

\subsection{Social and institutional aspects}

One single important determinant of sustainable sanitation system is the availability of a system at a lower administrative level that oversees the proper application of the sanitation system proposed (Mara, 2007). The system to oversee sanitation system is blurred at lower level. The capacity, roles and responsibilities of key institutional players in sanitation at lower levels are yet to form.

At the district level, sanitation services are overseen by two departments, namely, Water and Health Departments. At the village level, however, sanitation services are overseen by Health Department through a Health Officer who operates at the entire ward. Some wards do not have health officers; Kinole Ward for example had no health officer 
when this study was carried out. At the local level, health officers have to work with village health workers. However, due to lack of incentives, most of these village workers work in an ad hoc manner. In surveyed villages the workers were not even found. Households in villages are scattered with some of them being in very remote and difficult-to-access areas especially during rain seasons. It takes days for one health officer to reach all households for inspection. In addition to that the officer lack guidelines that could assist him or her in the delivery of hygiene education.

The Water Supply and Sanitation Act of 2010 requires that every village with water supply system form a water users association. The water users association is then charged with the mandate to oversee water supply and sanitation issues in the area. At the community meetings, members discuss water supply issues, but rarely do they mention sanitation issues.

\subsubsection{Perception of villagers on recommended sanitation technologies}

Sanitation status in surveyed villages is generally poor. While villagers realize the importance of improving sanitation; they feel that improvement is impossible because their income is low. One respondent was quoted saying, "hali yetu ndiyo hii kijana," meaning "this is all we can do, boy." Others are concerned about constructing permanent latrine due to frequent collapse of pits. They feel that the construction of permanent toilet is a wasteful investment. Pit collapse and tilting may in part be due to poor construction (sizing of logs), heavy rain, topography and weak pit walls, which are unlined thus easily attacked by mice. 
When recommended technologies were presented, the lack of awareness on the available sanitation options, usability, convenience, complexity, availability of water and limited local skills to construct and sustain the technology of choice were major reasons that were reported to hinder adoption of new technologies. In each village pictures of the five possible options were presented at the focus group discussion (see picture 1). Based on the local prices of materials, the cost of each sanitation technology was estimated in each village. Preference on technology, willingness to pay and perception were determined.
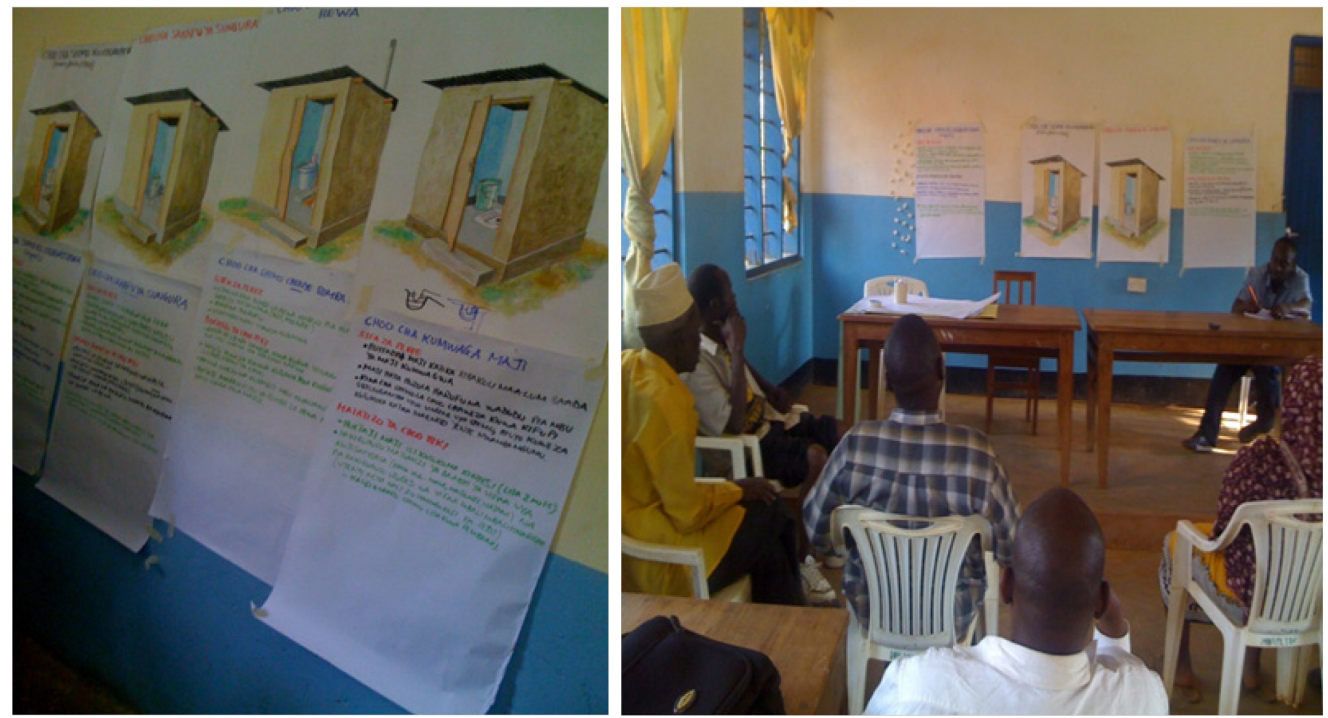

Picture 1: Pictures of sanitation technologies presented in focus group discussion

Preference on technology varied between villages but generally the Improved Floor Toilet was the most preferred, followed by VIP latrine, SanPlat and Pour Flush. Ecosan was not as preferred as others (see Fig.10).

Costs of each sanitation technology were estimated using local prices of materials in each village. The estimated costs of each sanitation technology in each village are 
explained in table 6. Unit prices and quantity of materials needed are described in Appendix IV.

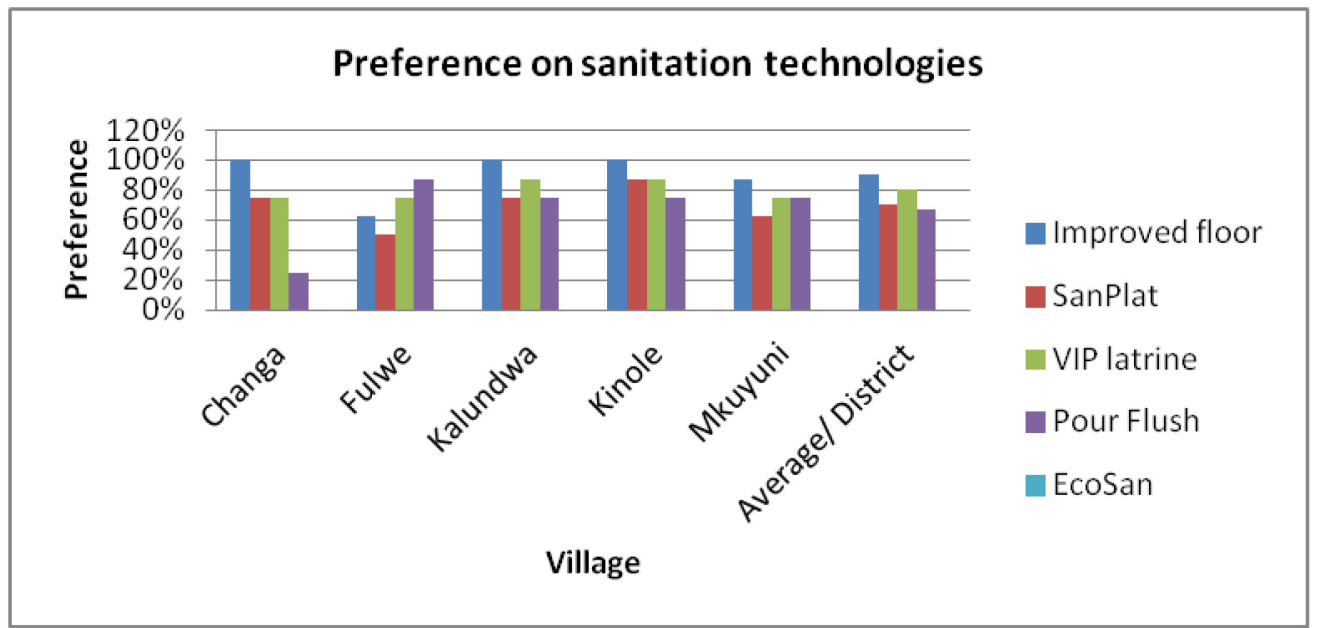

Figure 10: People's preference on recommended sanitation technologies

Table 6: Estimated costs of sanitation technologies in surveyed villages

\begin{tabular}{|l|c|c|c|c|c|}
\hline \multirow{2}{*}{ Villages } & \multicolumn{5}{|c|}{ Cost of Technologies in TZS } \\
\cline { 2 - 6 } & $\begin{array}{c}\text { Improved } \\
\text { Floor Toilet }\end{array}$ & SanPlat & $\begin{array}{c}\text { VIP } \\
\text { latrine }\end{array}$ & Pour Flush & EcoSan* \\
\hline Changa & 54,150 & 53,825 & 67,100 & 70,100 & 427,200 \\
\hline Fulwe & 68,100 & 67,800 & 71,200 & 74,700 & 427,200 \\
\hline Kalundwa & 49,350 & 49,050 & 63,400 & 65,100 & 427,200 \\
\hline Kinole/Tandai & 62,800 & 62,463 & 75,450 & 76,950 & 427,200 \\
\hline Mkuyuni & 63,150 & 54,950 & 67,100 & 70,100 & 427,200 \\
\hline
\end{tabular}

*the cost was not estimated by this study

The costs of EcoSan included the costs of sub structure and squatting pans as estimated by the Environmental Engineering and Pollution Control Organization (EEPCO) Tanzania and were assumed to be constant across all villages. Residents were not familiar with some accessories needed for this technology as such it was hard to estimate the cost. Further, the EcoSan floor was inseparable as how other technologies were treated. 
Economic and technical description of sanitation technologies was used to elicit people's perception on each technology and their willingness to pay for the particular technology. The aim was to see whether preference and willingness to accept a technology depended on its costs. The analysis of data shows that the estimated costs of technology did have a negative influence with willingness to pay but the relationship was not statistically strong $\left(R^{2}=0.049\right)$ (See Fig. 11).

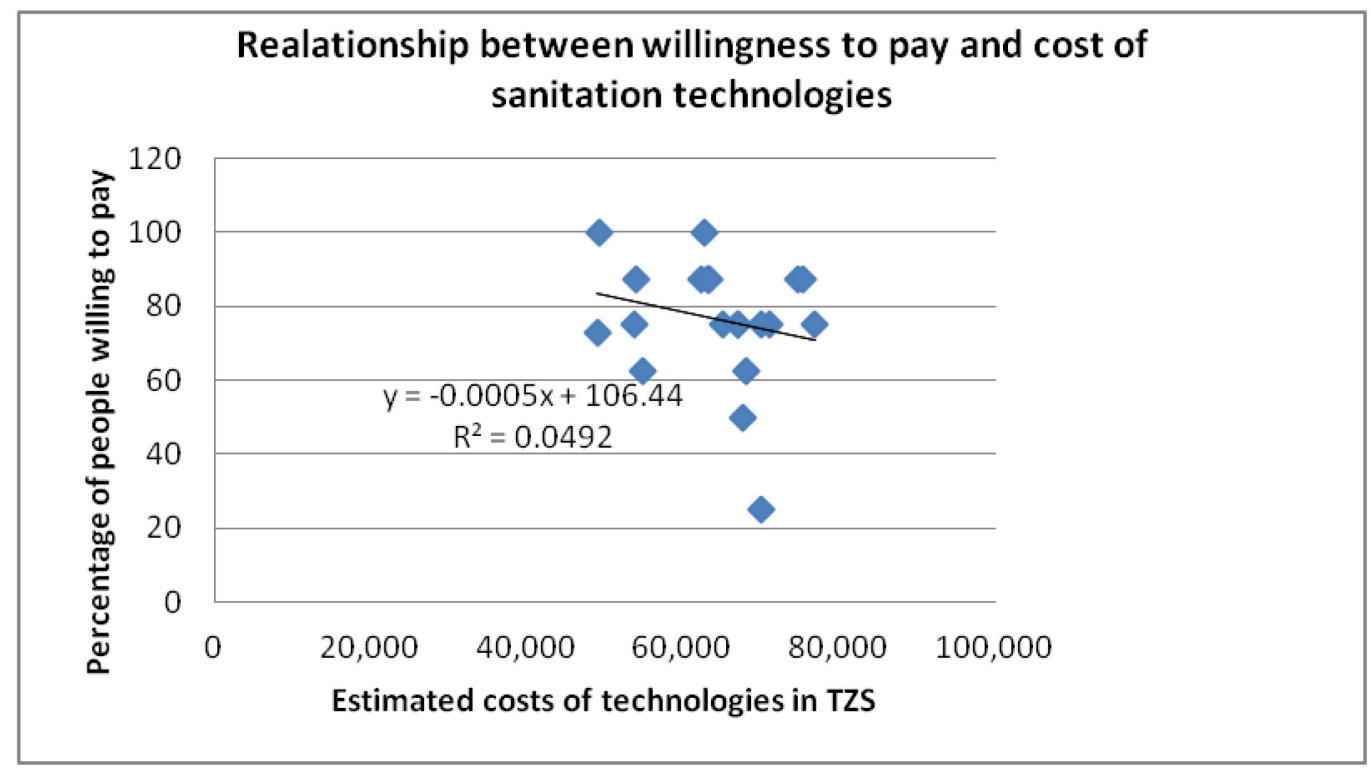

Figure 11: Willingness to pay and cost of sanitation technologies in surveyed villages

In this regard, respondents may likely prefer technologies based on factors other than costs. In focus group dicussions, respondents in each village made comment on each technology and explained their perception. Table 7 summarizes responses of participants about each technology in all villages where as responses from each village are presented in Appendix V.

Improved floor toilet was the most preferred technology in all villages but Fulwe, because it was viewed as simple to construct and easy to improve. It offers opportunity 
for improvement like installing squatting pan or vent pipe. Participants also thought that improved floor toilet does not induce dependence on external knowledge on construction of toilets because local artisans who build main house can also be used to build a toilet without special training. The technology however, is not popular in Fulwe due to its disadvantages, such as smell and size of pit hole.

Table 7: General perception about the recommended technologies

\begin{tabular}{|c|c|c|}
\hline & Technology & General perception \\
\hline 1 & Improved (Floor) Toilet & $\begin{array}{l}\text { - Simple and affordable } \\
\text { - Local artisans can construct one; skilled } \\
\text { personnel can be expensive especially after } \\
\text { receiving special training }\end{array}$ \\
\hline 2 & SanPlat & $\begin{array}{l}\text { - No trained personnel in the village to build } \\
\text { one } \\
\text { - Time may be required before the slab is re- } \\
\text { used; two slabs may thus be required for } \\
\text { alternation (unsightly and smell from full } \\
\text { up toilet discourage re use of slab) }\end{array}$ \\
\hline 3 & VIP Latrine & $\begin{array}{l}\text { - It is a common technology } \\
\text { - Children may get used to darkness inside } \\
\text { - The technology looks more improved than } \\
\text { a majority of the main houses in the } \\
\text { village, i.e., the toilet does not match with } \\
\text { main house }\end{array}$ \\
\hline 4 & Pour Flush & $\begin{array}{l}\text { - Looks very advanced technology } \\
\text { - Water supply not reliable } \\
\text { - Expensive } \\
\text { - Majority are Muslim, use of water for anal } \\
\text { cleansing is compatible with practices. }\end{array}$ \\
\hline 5 & EcoSan & $\begin{array}{l}\text { - Farms are far away to carry fertilizer to } \\
\text { - Negative attitude on human feces; fear of } \\
\text { being laughed at when noticed that one } \\
\text { carrying feces } \\
\text { - Technology perceived advanced and very } \\
\text { new } \\
\text { - Fear that customers may not buy produces } \\
\text { nourished by human excreta }\end{array}$ \\
\hline
\end{tabular}


Kalundwa village has limited access to water supply yet residents preferred pour flush toilet. The main reasons were that residents viewed other technologies as inferior and that they did not want to opt for an inferior technology. Further the village has limited access to safe water supply, and therefore, choosing a technology that requires water supply was seen as a way to pressurize government to supply more and safer drinking water to their village.

SanPlat technology was simple and was the cheapest technology among all technologies in all villages. The technology however wasn't much preferred for it required trained artisans. Their experience was that trained artisan frequently left their villages or had standardized cost that may be hard to bargain by the majority of people in the village. Local artisans were trained at Fulwe village in 2005. During this survey however none of the trained artisan was found. The trained artisans either left the village or changed carrier. Residents were hesitant to accept the idea of re-using the Sanplat slab. Several of the households expressed that they would need more time before they uninstalled a full pit and installed a new one. The smell and unsightly situation of a full pit may be discouraging.

Villagers did not prefer ecological sanitation or EcoSan. The technology was seen as a complex and expensive, and the fertilizer it provided was not required at the time being. While residents planted banana trees in abandoned toilet pits, they did not want to eat those bananas themselves but sold them. Another limitation of adopting EcoSan was that farms are very far away from the villages they live and as such carrying excreta/fertilizer may be required, an idea that didn't sound socially acceptable to them. 


\subsection{Sustainability of technologies}

Residents have preference on certain types of sanitation options. The physical environment and other factors however may limit the use of the sanitation technology of their choice. For instance, the pour flush toilet may be preferred by villagers, but the fact that water may be in short supply in that particular village may limit its adoption. Some residents may also like to construct an Ecosan but the unavailability of material locally or skills may hinder its feasibility. The villagers nevertheless have to use one of the improved sanitation technologies in order to improve their health and social well being. A balance has to be sought to assist communities to choose 'appropriate' sanitation technology that is compatible with their financial ability and willingness to pay, social compatibility, physical environmental characteristics, and the characteristics of technology. The following sustainability assessment is one of the ways to determine what that appropriate technology would be for each village.

This study assessed sustainability of technologies by calculating composite sustainable development index $\left(I_{C S D}\right)$. The calculation was accomplished on an excel spread sheet as illustrated in Appendix VI. The calculation of $I_{C S D}$ took into consideration the weights of the four criteria: social factor, affordability, technical feasibility, and environmental factor. Experts working in the area of sanitation, hygiene and water supply ranked the factors in a pair-wise comparison.

Using average weights from the pair-wise comparison matrix, (refer table 3), the factors can be ranked as seen in Fig. 12. Social factors were ranked the highest while environmental factors were ranked the least. 


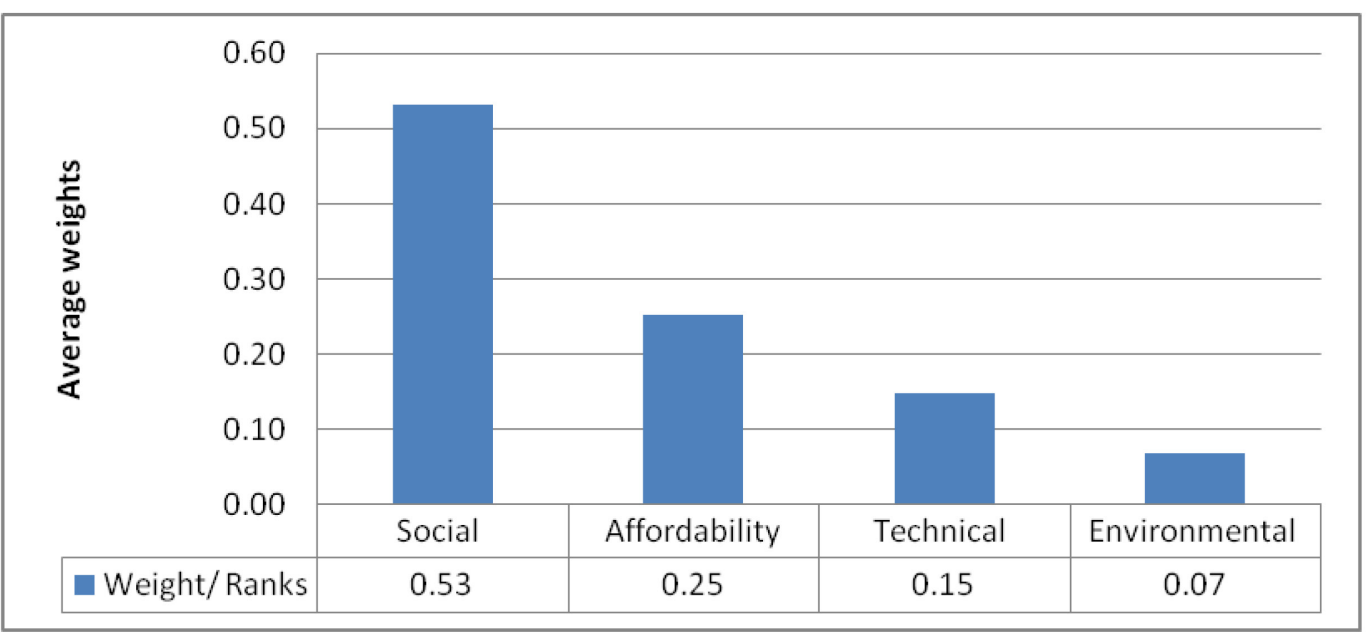

Figure 12: Ranking of sustainability factors using average weights

Each sustainability factor or criterion had more than one indicator. In calculation of composite sustainable development index $\left(I_{C S D}\right)$, weights of indicators within a criterion were assumed to be equal. Their values however had to be derived through developing different rubrics of scales.

The scales of rubrics were derived from the characteristics of the area and the requirements of technology. For example, the rubric for impacts on forest was set up on basis of extent that a village demanded wood from forests for constructing toilets that require wood, e.g., SanPlat. The extent of the impact was estimated using the national target for increasing access to improved sanitation under the National Strategy for Growth and Poverty Reduction II (MoFEA, 2010). A three scale rubric of scale 0 to 2 was used for this purpose. The value of 0 means the technology implementation would need a lot more wood making a large adverse impact on forests. The rubric measure 1 means that the impact on forests is moderate because the number of $\mathrm{HH}$ required to improve toilets is less than the number estimated by the government. The rubric measure 2 means that the impact on forest is unlikely for a technology does not require forest 
instead uses concrete slabs (for example, VIP latrine). The government is planning to increase the current level of access to improved sanitation of $23 \%$ of $\mathrm{HH}$ to the national target of $35 \%$ by 2015 (MoFEA, 2010). Some survey villages already had more than $23 \%$ coverage; for example, Fulwe village had a coverage of $25 \%$. Therefore, the forest impact value for this village would be 2, meaning a low impact on its forests because the number of $\mathrm{HH}$ that require improved toilets is lower. Some villages had coverage less than the national baseline coverage of $23 \%$; for example, Changa village had a coverage of $2 \%$. In this case if toilets that use woods are adopted, the impact will be the highest and would receive an impact value of 0 . Similar rubric was developed for other indicators and are presented in Appendix III.

\subsubsection{Ranking of technologies using ( $\left.\mathrm{I}_{\mathrm{CSD}}\right)$}

Figure 13 presents the composite sustainable development index $\left(\mathrm{I}_{\mathrm{CSD}}\right)$ values for each technology and in each village.

\begin{tabular}{|c|c|c|c|c|c|c|c|}
\hline \multicolumn{8}{|c|}{ Ranking sanitation technologies based on ICSD } \\
\hline \multirow{7}{*}{ 븜 } & 0.70 & & & & & 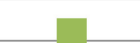 & \\
\hline & 0.50 & & & & & E & \\
\hline & 0.40 & & & & & & \\
\hline & 0.30 & & & & & & \\
\hline & 0.20 & & & & & & \\
\hline & 0.10 & & & & & & \\
\hline & 0.00 & Changa & Fulwe & Kalunda & Kinole & Mkuyuni & Districst \\
\hline \multicolumn{2}{|c|}{ Improved Floor Toilet } & 0.40 & 0.62 & 0.30 & 0.35 & 0.56 & 0.45 \\
\hline \multicolumn{2}{|c|}{ SanPlat } & 0.66 & 0.65 & 0.38 & 0.46 & 0.48 & 0.53 \\
\hline \multicolumn{2}{|c|}{ VIP Latrine } & 0.43 & 0.61 & 0.35 & 0.38 & 0.66 & 0.48 \\
\hline \multicolumn{2}{|c|}{ Pour Flush } & 0.27 & 0.62 & 0.35 & 0.44 & 0.58 & 0.45 \\
\hline \multicolumn{2}{|c|}{ Ecosan } & 0.23 & 0.35 & 0.27 & 0.32 & 0.35 & 0.30 \\
\hline
\end{tabular}

Figure 13: Ranking of sanitation technologies by $I_{C S D}$ in surveyed villages 
On average (district), SanPlat toilet has higher $\left(I_{C S D}\right)$ value $(0.53)$, followed by VIP latrine (0.48) while Ecosan has the lowest $I_{C S D}$ value (0.30). Therefore, the most sustainable sanitation technology in the district is SanPlat toilet followed by VIP latrine, the improved floor, the Pour Flush toilets and the EcoSan. This ranking however differs from people's preference. When opportunity was given to residents to rank technologies according to their preference, the Improved Floor toilet was their first choice while the same emerged as the third most sustainable technology based on the $I_{C S D}$ value (Fig.14).
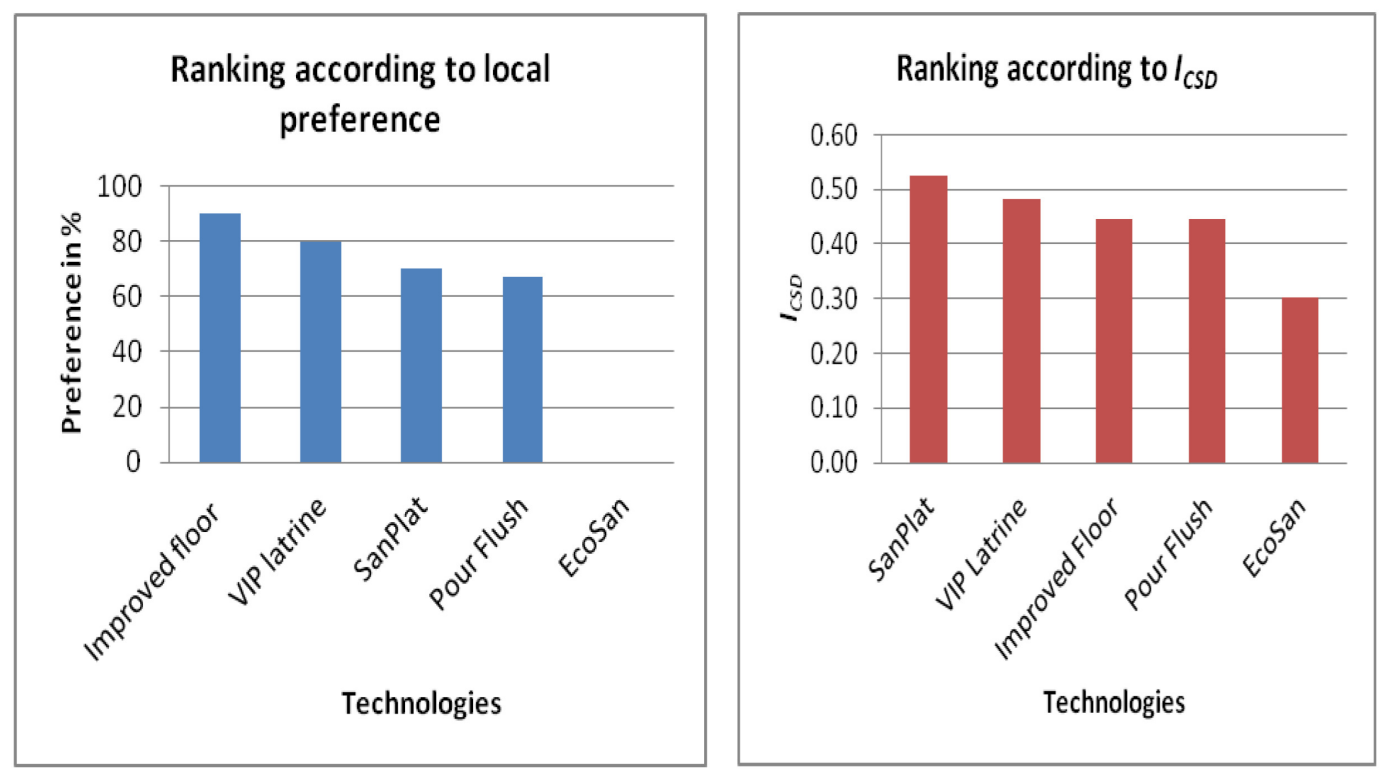

Figure 14: Ranking of sanitation technologies according to perception and $I_{C S D}$

The difference in the above two rankings reflects the differences in the contributions of various criteria that are considered in this study towards the sustainability of sanitation technologies. These contributions can be easily ascertained by carefully looking at the values of sustainability sub-indices $\left(I_{S}\right)$ for each technology and each village. 
In Kinole/Tandai village for instance, SanPlat toilet had higher $\left(I_{C S D}\right)$ followed by the pour flush toilet instead of VIP latrine. The $I_{s-} S o c$ value for Pour Flush (PF) toilet was higher than that of VIP latrine. The higher value of $I s-S o c$ was due to the higher value associated with the "convenience" factor in the use of a technology. Convenience was described as the extent to which users found it convenient to minorities (children, people with disability etc). The VIP latrine is dark inside, a feature that may scare children. To residents of Kinone darkness in a toilet may scare children, and therefore, an alternative was to go for a well illuminated small squatting pan's PF toilet which was user friendly to children. Figure 15 provide distribution of $I s$ values among technologies in Kinole village.

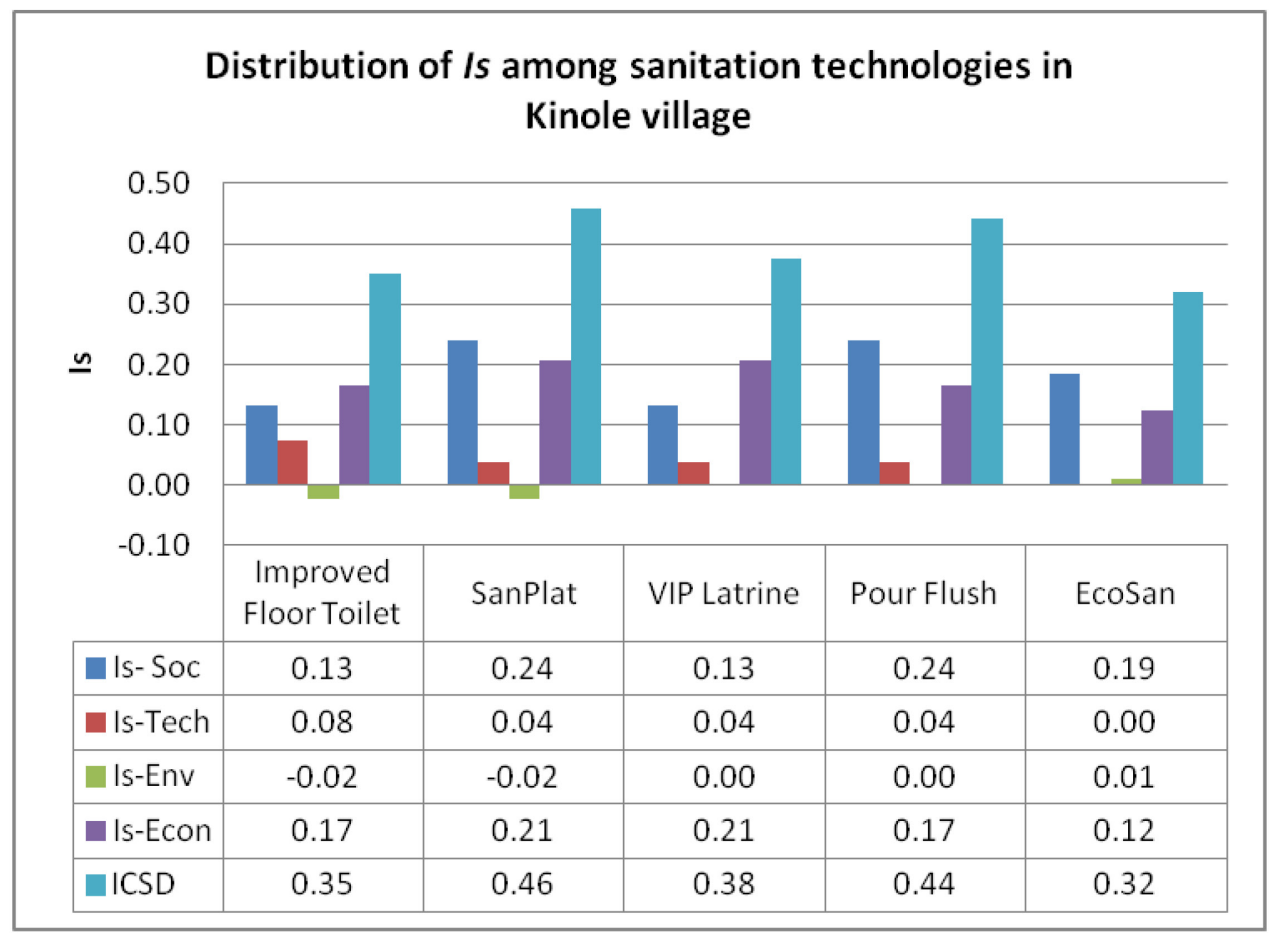

Figure 15: Distribution of $I s$ values among technologies in Kinole/Tandai village The downward bars of $I s-E n v$ for Improved floor and SanPlat toilets (in fig.15) are caused by the overall $I s-E n v$ value which is negative. The negative value describes 
negative impact the two technologies might have on forests. The two technologies use logs from forests for construction of slabs. The VIP latrine and the PF latrine has an overall zero $I s-E n v$ value meaning that the technologies might unlikely impact forests because they use ferrocement slab which replaces the logs.

The ecological sanitation technology is the only technology with overall positive Is - Env value over the other technologies. This is because the technology offers the opportunity to use the nutrients from the technology, a feature that was regarded as environmentally benign in this study.

In Mkuyuni village, VIP Latrine had higher $I_{C S D}$ value than the rest of technologies, which was contrary to the district average. Socially, the two technologies VIP Latrine and SanPlat toilet technologies are equally convenient and user friendly. To Mkuyuni residents however, VIP latrine was their first preference (75\%) than SanPlat toilet (62.5\%). In this case the $I s-S o c$ for SanPlat was lower than that of VIP latrine.

The $I s-E n v$ for SanPlat was also lower than that of VIP latrine; this is due to the probable impact SanPlat toilet might have on Mkuyuni village natural forests. The VIP latrine utilizes no forest products. Also, Is-Econ value was higher for this technology, which was due to higher willingness to pay for VIP latrine than SanPlat toilet.

In Kalundwa village the ranking of sanitation technologies was almost the same as that of the district. In Fig.17, the value of $I_{C S D}$ for SanPlat was higher than both VIP and PF latrine, followed by Improved Floor toilet and Ecosan. 


\begin{tabular}{|c|c|c|c|c|c|}
\hline \multirow{4}{*}{$\begin{array}{l}0.70 \\
0.60 \\
0.50 \\
0.40\end{array}$} & \multicolumn{5}{|c|}{$\begin{array}{l}\text { The distribution of Is values among sanitation } \\
\text { technologies in Mkuyuni Village }\end{array}$} \\
\hline & & & & & \\
\hline & & & & & \\
\hline & & & & & \\
\hline$\underline{\simeq} \quad 0.30$ & & & & & \\
\hline 0.20 & & & & & \\
\hline 0.10 & & & & & 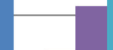 \\
\hline \multirow{2}{*}{$\begin{array}{r}0.00 \\
-0.10\end{array}$} & & & & & \\
\hline & $\begin{array}{l}\text { Improved } \\
\text { Floor Toilet }\end{array}$ & SanPlat & VIP Latrine & Pour Flush & EcoSan \\
\hline Is- Soc & 0.34 & 0.34 & 0.40 & 0.29 & 0.21 \\
\hline Is-Tech & 0.08 & 0.04 & 0.04 & 0.04 & 0.00 \\
\hline Is-Env & -0.02 & -0.02 & 0.00 & 0.00 & 0.01 \\
\hline Is-Econ & 0.17 & 0.12 & 0.22 & 0.25 & 0.12 \\
\hline CSDI & 0.56 & 0.48 & 0.66 & 0.58 & 0.35 \\
\hline
\end{tabular}

Figure 16: Distribution of $I s$ values among sanitation technologies in Mkuyuni village

\begin{tabular}{|c|c|c|c|c|c|}
\hline \multicolumn{6}{|c|}{$\begin{array}{l}\text { Distribution of Is among sanitation technologies in } \\
\text { Kalundwa village }\end{array}$} \\
\hline \multirow{8}{*}{$\begin{array}{r}0.40 \\
0.35 \\
0.30 \\
0.25 \\
0.20 \\
0.15 \\
0.10 \\
0.05 \\
0.00 \\
-0.05\end{array}$} & & & & & \\
\hline & & & & & \\
\hline & & & & & \\
\hline & & & & & \\
\hline & 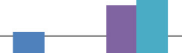 & & & & \\
\hline & & & & & \\
\hline & & & & & \\
\hline & $\begin{array}{l}\text { Improved } \\
\text { Floor Toilet }\end{array}$ & SanPlat & VIP Latrine & Pour Flush & Ecosan \\
\hline Is- Soc & 0.11 & 0.21 & 0.16 & 0.21 & 0.16 \\
\hline Is-Tech & 0.08 & 0.04 & 0.04 & 0.00 & 0.00 \\
\hline Is-Env & -0.02 & -0.02 & 0.00 & 0.00 & 0.01 \\
\hline Is-Econ & 0.14 & 0.15 & 0.15 & 0.14 & 0.10 \\
\hline CSDI & 0.30 & 0.38 & 0.35 & 0.35 & 0.27 \\
\hline
\end{tabular}

Figure 17: Distribution of Is values among sanitation technologies in Kalundwa village 
Generally across most study villages, the main determinants that bring variation in Is values are availability of water, availability of trained masons, and social acceptance. However the situation in Kinole/Tandai Village, a village with adequate supply of water, the availability of water did not seem to be the influential factor. In Kinole village SanPlat latrine seemed to be a more sustainable technology than the water based system, pour flush (see Fig.18).

The higher value of $I_{C S D}$ in Kinole village is explained by the higher values of economic factors (Is-Econ) - caused by the higher value of willingness to pay. The willingness to pay for SanPlat in the village was $87.5 \%$ while the willingness to pay for Pour Flush was $75 \%$. Residents saw that SanPlat was simple and affordable. They get rid of the pour flush toilet for fear of pit being frequently collapsing due to high rainfall (speedy run offs) and the topography. The residents probably find it more expensive to maintain in the long term.

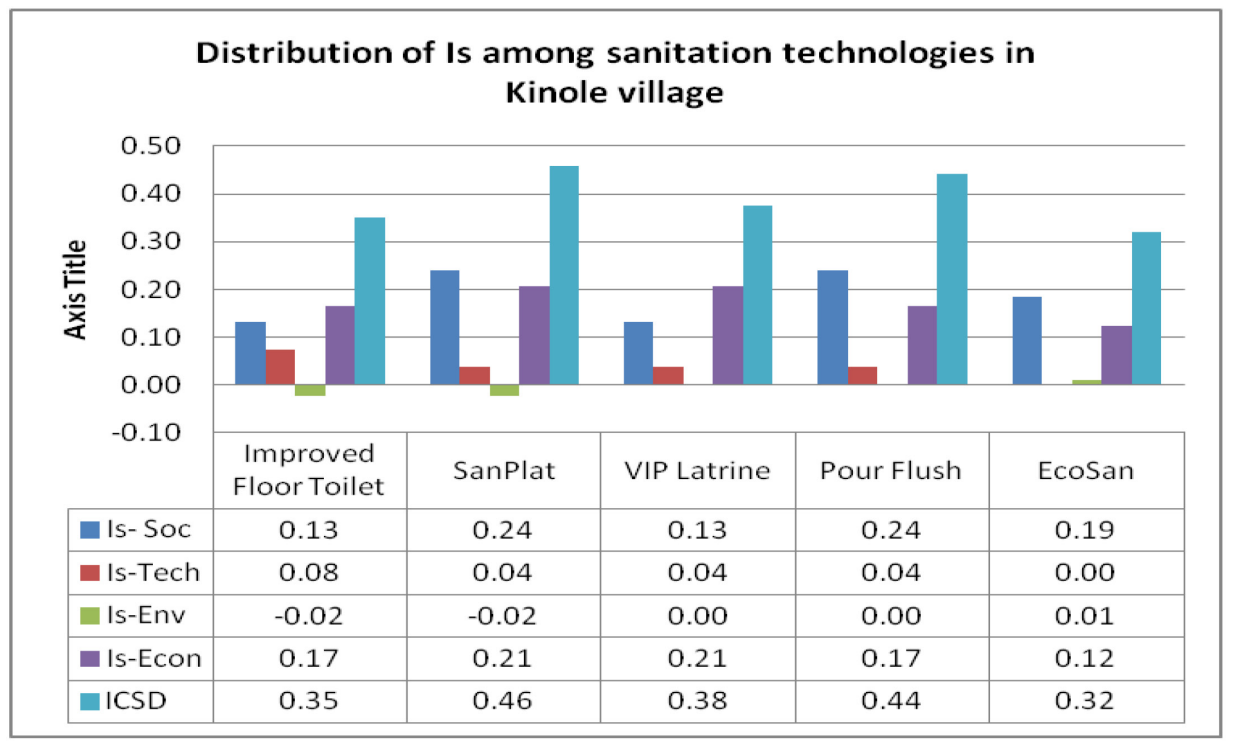

Figure 18: Distribution of $I s$ values among sanitation technologies in Kinole village 


\subsection{CONCLUSIONS AND RECOMENDATION}

The Rural Tanzania is known for reliance on poor sanitation technologies. Past studies have found strong relationship between poor sanitation and high morbidity and mortality, especially sanitation-related diseases like diarrhea. The national strategy for growth and poverty reduction has set targets for increasing improved sanitation services, but these targets remain far from being achieved. There has been no systematic study to understand the technical and socio-economic reasons people are slow to adopt improved sanitation technologies. The aim of this study was to assess the sustainability of sanitation technologies in rural Tanzania, based on a case study of Morogoro District. Specifically, the research assessed the existing sanitation conditions and the associated health, environmental and socio-economic problems in the study area. The study then made an attempt to determine the physical-environmental characteristics and socioeconomic and institutional factors influencing the adoption of alternative sanitation technologies. Further, the study applied a comprehensive framework of sustainability indicators to rank sanitation technologies based on established sustainability criteria.

\subsection{Existing sanitation conditions and the associated problems}

Sanitation status in the study area is generally poor; toilets are constructed with temporary materials. They have a mud floor, lack hand washing facilities and a mechanism for controlling odor and flies thus compromising environmental health. Incidence of diarrhea is high in villages with low coverage of improved sanitation. Socio-cultural lifestyle of people compounded with habitual behavior and low education level result into reliance on poor sanitation facilities and hygiene practices. In a study 
conducted in Dar es salaam, Tanzania, habitual behavior was also seen as a barrier to adoption of improved sanitation technologies (Chaggu et al., 2002).

Proportion of households with improved toilets $(9.4 \%)$ is lower than national level $(23 \%)$. Since the national estimate is used to set target, these villages are likely to remain behind other villages by 2015. Further, sanitation coverage in the rural area is likely to lag behind coverage in urban areas in general because the initial sanitation target itself is set lower in rural areas than in urban areas. As documented in the National Strategy for Growth and Reduction of Poverty (NSGRP II), 2010 to 2015, the target is to increase the number of households using improved toilets from 23 percent in rural areas and 27 percent in urban areas in 2010 to 35 percent rural areas and 45 percent urban areas in 2015 (MoFEA, 2010). Demand for sanitation are even higher in rural areas given their higher number and limited access to health services, more effort are needed to improve access to sanitation in rural areas.

\subsection{Factors influencing adoption of alternative sanitation technologies}

Limited access to adequate quantities of water may not limit the adoption of water based technologies. There is adequate supply of water in Kinole than in Fulwe village, yet residents in Kinole prefer SanPlat than Pour Flush due to other reasons. Access to water was limited at Fulwe village yet PF toilet was a most preferred technology and as

well a sustainable technology than non water based technology like VIP latrine. This indicate that selection of technology appropriate to an area has to consider social characteristics of the locality especially preferences. 
This study finds that in places where water table is higher, soil is loose and gravelly, and burrowing animals are dominant, residents excavate shallow pits, which provide poor sanitation service. Toilets in these villages lack cement floor and exposed to outside weather (speedy run of, heavy rain and sloppy land) leading to their frequent collapse. This calls for education on pit strengthening techniques and proper location in order to protect both public health and the environment.

\subsection{Sustainability of sanitation technologies and final ranking}

The study results indicate that physical, socio-cultural, economic and institutional characteristics of the area favor introduction and adoption of recommended new sanitation technologies to a certain extent. Local characteristics determined the extent to which one technology could be regarded most sustainable than the other. Factors like lack of trained personnel, water table level, awareness about the available technology, institutional framework at lower level are some of the area that determine sustainability of a sanitation technology in a given locality.

On basis of composite sustainable development index $\left(I_{C S D}\right)$, the proposed sanitation technologies may be sustainable in the order of most sustainable to least sustainable: (1) SanPlat toilet, (2) VIP latrine, (3) Improved/cement mortar floor, (4) Pour flush toilet, and (5) EcoSan. The ranking differs from people's preferences, the observation that signifies the importance of community participation in decision making.

Identification of most appropriate and sustainable sanitation technology paves a way for technology improvement in rural Tanzania. The most sustainable technology may be first introduced on a pilot basis and ensuring effective local participation. The 
two way feedback mechanism that will facilitate redesign and improvement of the technology to a level that meets demands of users is critical. Based on the study results, we draw the following policy recommendations:

1. Residents have to be educated on health benefits of impervious floor. Impervious floor is important even though main house does not have one (cement floor).

2. Education on low cost techniques for pit lining has to be provided to avoid frequent pit collapse.

3. People have to be educated on risk and benefit associated with reuse of squatting slab and nutrients from toilets. When one knows the benefit, he or she may find a way to achieve it. For instance, during this study, we observed many local modifications of pour flush system, which aimed at reducing the amount of water for flushing.

4. Residents have to be informed of the available sanitation options given the physical environment characteristics of their area.

5. Hand washing facilities were rare but people use water stored as washers to wash their hands without soap. Further research may be required to assess whether washing hand with soap using water stored as washer may render hands free from fecal contamination.

6. The system that oversees sanitation need to be strengthened to ensure adequate consultation for villagers on proper sanitation technologies and hygiene practices. This goes together with continuous monitoring of progress in access to improved sanitation, sanitation-related communication and training. Such progress must be documented in important district and national reports. 
7. The model for assessing sustainability of sanitation technologies by aggregating different criteria (socio, economic, environmental and health) and indicators is effective in assessing sustainability of sanitation technologies.

8. While village or district level comprehensive (aggregate) indicators may be useful in ranking multiple technologies, it is important to look into constituent or subcomponent indicator values for specific village or technology in order to understand the effect or significance of extreme factors. Such extreme factors shed light on the need for specific policies promoting sanitation improvement (e.g., education, government incentives, etc.).

9. Ward health officer and other staff working in the area of sanitation and hygiene should be exposed to available low cost improved sanitation technologies and innovative community participatory approaches. This is an important strategic area in human and institution capacity development and may help rural Tanzania meet its national targets for sanitation and hygiene in a timely fashion. 


\section{REFERENCES}

Basu, S. and Weil, D.N. (1998). Appropriate technology and growth. Quarterly Journal of Economics 113 (4), 1025-1054.

Bird, C.F.E (1994. Cliff Hazard and Coastal Management. In Coastal Hazards, Perception, Susceptibility and Mitigation, Finkl W.C. Jr. (Editor). The coastal Education and Research Foundation (CERF). Charlottesville, Virginia, and Fortd Lauderdale, Florida pp. 299-309

Brandberg, B. (1996). New Strategies for Community-based Sustainable Sanitation Programmes Using SanPlats and the New SanPlat Moulds, revised edition. SBI Consulting and Supplies, Mbabane, Swaziland (SanPlat details are given at www. sanplat.com).

Chaggu, E., Mashauri, D., Buuren, J., Sanders, W. and Lettinga, G. (2002). Excreta Disposal in Dar-es Salaam. Environmental management, 30(5), 0609-0620

Checkley, W., Gilman, R.H., Black, R.E., Epstein, L.D., Cabrera, L., Sterling, C.R. and Moulton, L.H. (2004). Effect of water and sanitation on childhood health in a poor Peruvian peri-urban community. The Lancet, 363(9403), pp. 112-118.

Cleavan, F. and Toner, A. (2006).The evolution of community water governance in Uchira, Tanzania: The implications for equality of access, sustainability and effectiveness. Natural Resources Forum; . 30(3). p207-218, DOI: 10.1111/j.14778947.2006.00115.x

Crang, M. and Cook, I. (2007). Doing ethnographies, Sage

Diwan, R and Livingston, D. (1979). Alternative Development Strategies and Appropriate Technology: Science Policy for an Equitable World Order, Pergamon Press. New York.

Dzwairo, B., Hoko, Z., Love, D. and Guzha, E. (2006). Assessment of the impacts of pit latrines on groundwater quality in rural areas: A case study from Marondera district, Zimbabwe. Physics and Chemistry of the Earth, Parts A/B/C, 31(15-16), 779-788

Eisenberg, J. N., Scott, J. C., Porco, T. (2007). Integrating disease control strategies: Balancing water sanitation and hygiene interventions to reduce diarrheal disease burden (plus letter and reply). Am. J. Public Health, 97 (5), 846-852.

Global Alliance for Community Development; Accessed on 4/30/2012 shttp://www.thegacd.org/Our\%20Programs/Health/Health.html 
Geoff, C. (2004). The Analytic Hierarchy Process (AHP). Practical Strategy. Open Access Material. AHP. Pearson Education Limited

Griggs B.G. (1994). California's Coastal hazards. In Coastal Hazards, Perception, Susceptibility and Mitigation. Finkl W.C Jr. (Editor). The coastal Education and Research Foundation (CERF). Charlottesville, Virginia, and Fortd Lauderdale, Florida pp. $1-15$

Hall, B. (1978). Mtu ni Afya. Tanzania's Health Campaign. Clearinghouse, Washington, DC, USA.

Harvey, P.A., Baghri, S. and Reed, R.A. (2002). Emergency Sanitation: Assessment and programme design. WEDC, Loughborough University, UK.

Hoko, Z. and Hertle, J. (2006). An evaluation of the sustainability of a rural water rehabilitation project in Zimbabwe. Phys. Chem. Earth, 31. 699-706

Howard, G. and Bartram, J. (2003). Domestic water quantity, service level and health. World Health Organisation, Geneva

International water and sanitation centre (IRC). (2012). http://washhelpdesk.wordpress.com /2010/11/25/ differences-between-on-site-sanitationand-off-site-sanitaton-zimbabwe/. Accessed on 5/6/2012

Igulu, S.B. (2010). Household factors contributing to recurrent episodes of acute diarrhoea in children under the age of five years in Kinondoni- Tanzania. Master's Thesis. Lund University

Jensen, P.K., Phuc, D.P., Dalsgaard, A., Konradsen, F. (2005). Successful sanitation promotion must recognize the use of latrine wastes in agriculture - the example of Vietnam. Bull. WHO 83, 873-874.

Jequier, N. and Blanc, G. (1983). The World of Appropriate Technologv A Qualitative Analysis. Development Centre of the Organization for Economic Co-operation and Development, Paris. P. 6.

Kabongo, I. and Charles, K., (2008). Pit Latrines \& their Impact on Groundwater in Small Towns in Uganda A case of Bugiri Town Council

Katukiza, A. Y., Ronteltap, M., Oleja, A., Niwagaba, C. B., Kansiime, F. \& Lens, P. N. L. (2010). Selection of sustainable sanitation technologies for urban slums -- A case of Bwaise III in Kampala, Uganda. Science of The Total Environment, 409, 52-62.

Knappett P.S.K., Escamilla, V., Layton, A., McKay, L.D., Emch, M., Williams, D.E., Huq, R., Alam, J., Farhana,L., Mailloux, B.J., Ferguson, A., Sayler, G.S., Ahmed, K.M., 
van Geen, A., (2011). Impact of population and latrines on fecal contamination of ponds in rural Bangladesh. Science of The Total Environment, 409(17), 3174-3182

Krajnc, D. and Glavič, P. (2005). A model for integrated assessment of sustainable development. Resources, Conservation and Recycling, 43(2), 189-208

Kvarnström E., Bracken, P., Ysunza, A., Kärrman, E., Finsson, A. and Saywell, D. (2004). Sustainability Criteria in Sanitation Planning, 30th WEDC International Conference, Vientiane, Lao PDR.

Lahiri, S. and Chanthaphone, S. ( 2003). Water, sanitation and hygiene, a situation analysis paper for Lao PDR. Int. J. Environ. Health Res., S110-S117. http://www.who.int/mediacentre/factsheets/fs330/en/index.html accessed on 2/25/2012

Leone, T., Coast, E., Randall, S., (2009). Did you sleep here last night? The impact of the household definition in sample surveys: A Tanzanian case study. Presentation at British Society for Population Studies annual conference, September 9-11, Brighton, England.

Lockwood, H., Smits, S., Schouten, T., Moriarty, P. (2010). Providing Sustainable Water Services at Scale. International Symposium on Rural Water Services, Kampala 13th to 15 th April, 2010

Loetscher, T. and J. Keller. (2002). A decision support system for selecting sanitation systems in developing countries. Socio-economic planning sciences, 36(4), 267-290

Lyimo, C.W, Shayo, R, Lyimo T.J, (2008). Community Awareness on Microbial Water Pollution and Its Effects on Health Development in Urban Tanzania: A Case Study of Tabata and Kiwalani Wards in Ilala District in Dar es Salaam Region. Tanzania Journal of Development Studies 8(2)

Lynch, J. and Kaplan, G.A. (2000). Socioeconomic position. In: Berkman LF, Kawachi I, eds. Social Epidemiology. New York: Oxford University Press. Pp 13-35

Los, B. and Timmer, P. (2005). The 'appropriate technology' explanation of productivity growth: An empirical approach. Journal of Development Economics 77, 517-531.

Mara, D., Drangert, J., Anh N., Tonderski, A., Gulyas, H., Tonderski, K. (2007). Selection of sustainable sanitation arrangements. Water Policy 9:305-18

MDC (Morogoro Distric Council) 2011. District Socio-economic Profile, 2011.

Malisie, F. A. (2008). Sustainability Assessment on Sanitation Systems for Low Income Urban Areas in Indonesia. $\mathrm{PhD}$ Dissertation, Hamburg University of Technology (TUHH) 
Mara, D. D. (1985). The Design of Ventilated Improved Pit Latrines. TAG Technical Note No. 13. The World Bank, Washington, DC (available at www.leeds.ac.uk/civil/ceri/ water/tphe/ publicat/watsan/watsan.html).

Mara, D. D. (1985b). The Design of Pour-Flush Latrines. TAG Technical Note No. 15. The World Bank, Washington, DC (available at www.personal.leeds.ac.uk / cen6ddm/ wbreports.html).

McCubbin, N. C., (2007). Determinants of sustainability in rural sanitation: Village level factors influencing sustained latrine uptake. March 2007 progress report, prepared for WaterAid Tanzania

Ministry of Health and Social Welfare (2009). Sanitation and hygiene Policy - Draft. Dar es salaam

Ministry of Health and Social Welfare (2010). Latrine Options And Construction GuideDraft

Ministry of Finance and Economic Affairs (MoFEA) [Tanzania]. (2010). National Strategy for Growth and Reduction of Poverty (NSGRP) II. ISBN: 978-9987-08101-1. Available online at Website: www.povertymonitoring.go.tz; www.mof.go.tz; www.tanzania.go.tz

Morgan, P. R. \& Mara, D. D. (1982). Ventilated Improved Pit Latrines: Recent Developments in Zimbabwe. Technical Paper No. 3. The World Bank, Washington, DC (available at www-wds.worldbank.org/servlet/WDSContentServer/WDSP/IB/

2000/09/14/000178830_98101904151810/Rendered/PDF/multi_page.pdf).

Mtungila, J. and Chipofya, V. (2009). Issues and challenges of providing adequate sanitation to people living on the shore of Lake Malawi: Case of Monkey Bay, Malawi. Desal, 248(1-3), 338-343

Murphy, H. M., McBean, E. A., and Farahbakhsh, K. (2009). Appropriate technology - A comprehensive approach for water and sanitation in the developing world. Technology in Society, 31(2), 158-167.

National Bureau of Statistics (NBS), 2010. Tanzania Demographic and Health Survey (TDHS). Dar es Salaam, Tanzania: NBS and ICF Macro.

Nelson, K. L., and Murray, A. (2008). Sanitation for unserved populations: Technologies, implementation challenges, and opportunities. Annual Review of Environment and Resources, 33, 119-119-151.

Parente, S.L., Prescott, E.C. (1994). Barriers to technology adoption and development. Journal of Political Economy 102 (2), 298-321. 
Practical Action, 2012. Types Of Toilet And Their Suitability. The Schumacher Centre for Technology and Development, Bourton on Dunsmore, Rugby, Warwickshire, CV23 9QZ, UK www.practicalaction.org

Roy, A. K., Chatterjee, P. K., Gupta, K. N., Khare, S. T., Rau, B. B. \& Singh, R. S. (1984). Manual on the Design, Construction and Maintenance of Low-cost Pour-flush Waterseal Latrines. TAG Technical Note No. 10. The World Bank, Washington, DC (available at http://www wds.worldbank.org/servlet/ WDSContentServer/ WDSP/IB/ 2000/03/03/000178830

98101903445485/Rendered/PDF/multi0page.pdf).

Saaty, T.L. (1980). Analytical Hierarchy Process: Planning, Priority Setting, Resource Allocation. NewYork: McGraw-Hill;

Saaty, T. L. and Vargas G. L. (2001). Models, Methods, Concepts \& Applications of the Analytic Hierarchy Process. Boston: Kluwer Academic Publishers

Sustainable Sanitation Alliance (2011). What is sustainable sanitation? . Sustainable Sanitation Alliance. http://www.susana.org/lang-en/intro. Accessed on October 21, 2011.

Thomas J.C, Weber, D.J. (2001). Epidemiologic Methods for the Study of Infectious Diseases. New York, NY: Oxford University Press, 2001. ISBN 0-19-512112-0

UN (United Nations). (2010). The Millennium Development Goals Report. United Nations, New York

UN-WWAP (United Nations World Water Development Programme). (2006). The United Nations World Water Development Report 2: 'Water, a shared responsibility'. Paris and France, UNESCO and Berghahn Books

UN (United Nations). (2010). The Millennium Development Goals Report. United Nations, New York Whittington, D., 2011. Pricing Water and Sanitation Services., 79-95

The U.S Bureau of Democracy, Human Rights, and Labor, (2009). International Religious Freedom, 2009 report. Accessed on 07/24/2012 at http://www.state.gov/j/drl/rls/irf/2009/127259.htm.

Van der Vleuten-Balkema, A. (2003). Sustainable Wastewater Treatment-Developing a Methodology and Selecting Promising Systems. PhD Thesis. The Netherlands

WHO (World Health Organization). (2012). Diarrhoeal disease. Facts And Figures updated on August 2009. Available at http:// www.who. int/ mediacentre /factsheets /fs330/ en/ index.html 
WHO (World Health Organization). (2004). Water, Sanitation and Hygiene Links to Health . Facts And Figures updated on November

WHO (World Health Organization). (1992). A Guide to the Development of on-Site Sanitation

WHO/UNICEF (World Health Organization/United Nations, Children's Fund). (2012). Progress on Drinking Water and Sanitation: 2012 Update. WHO/UNICEF Joint Monitoring Programme for Water Supply and Sanitation. ISBN: 978-92-806-4632-0 (NLM classification: WA 670)

WHO/UNICEF-JMP (World Health Organization/United Nations Children's Fund Joint Monitoring Programme). (2010). http://www.wssinfo.org/definitionsmethods/introduction/. Accessed on October 21, 2011. 


\section{APPENDICES}

Appendix I: Description of technologies used for assessment

1. Improved-cement floor- Toilet

- Is a simple pit latrine that with a floor made with rot resistant wood, covered with mud and cement mortar

- Allows range of anal cleansing material and other solid material e.g. menstrual pads

- Does not require water to operate

- Construction costs are usually low - household can perform a large part of the work

- Fly and smell is a nuisance and there is possibility of ground water contamination if the pit is not lined

- Not easy to construct in rocky or unstable ground (Practical Action, 2012)

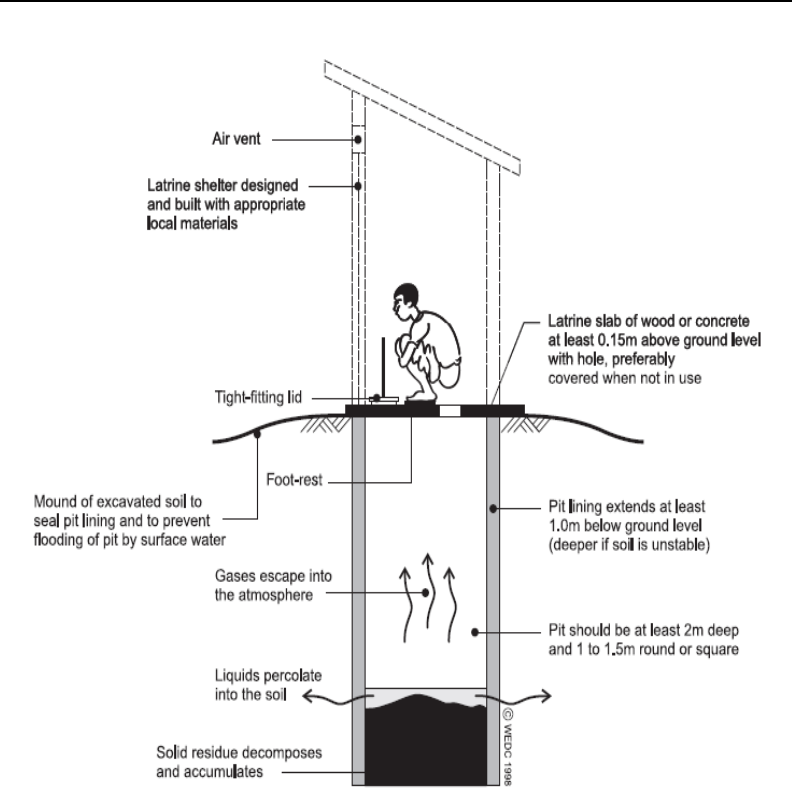

(Harvey et al, 2002 in Practical Action, 2012)

2. SanPlat - Toilet

- Is a simple pit latrine with unreinforced concrete slab called sanitation platform

- Has smooth and sloping surfaces which encourages regular cleaning

- Has elevated footrests to help the user find the right position, even at night.

- Has a drop hole that is both comfortable to use and safe even for small children

- Can be made with a tight fitting lid which stops smell and flies.

- It does not require water for its operation

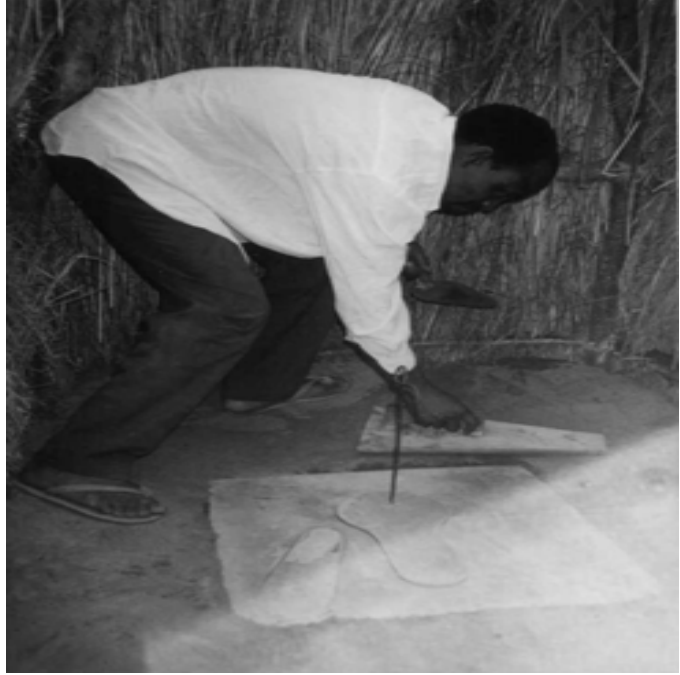

Photo by EEPCO 2002 in Shayo and Chaggu, (Mara et al 2007; Brandberg, B. 1996) 
3. Ventilated Improved pit latrine

- Is a pit latrine with the pit and the superstructure slightly offset to permit the installation of an external vertical vent pipe fitted at its top with a fly screen

- Has a vent pipe to exhaust fecal odor and a screen to minimize fly breeding. Allows the use of a range of anal cleansing materials

- Does not require water for operation

- Not easy to construct in rocky or unstable ground

- Does not control mosquitoes

- Vent pipe increases costs and can make construction more complicated

- Need to keep inside of latrine dark (Practical Action, 2012)

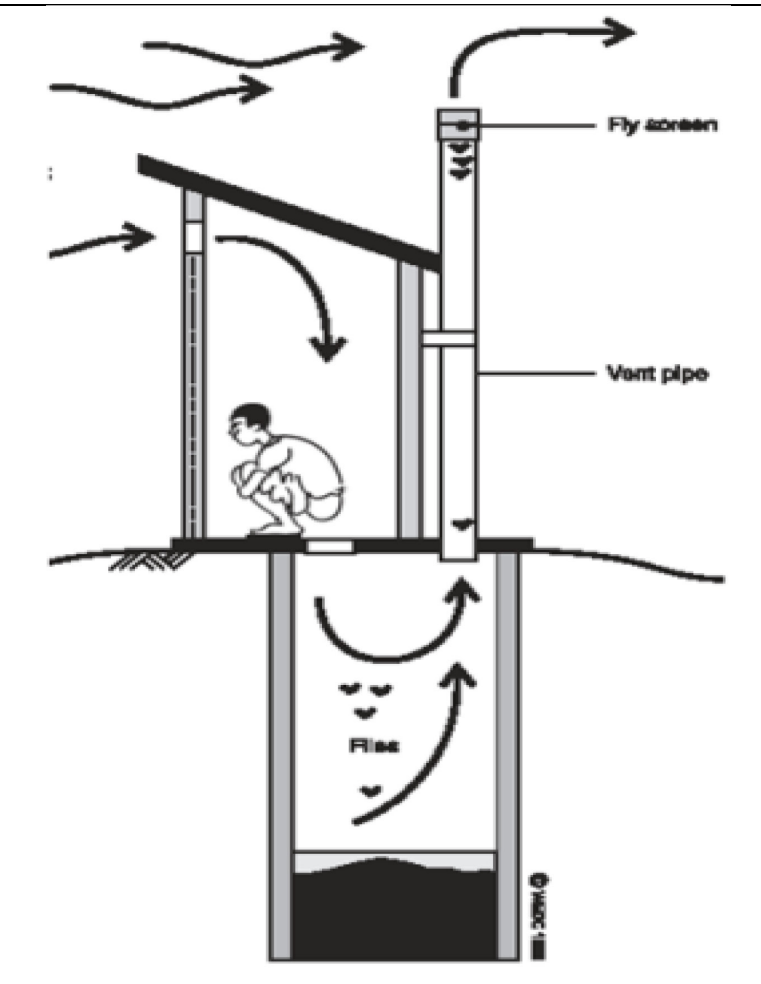

(Harvey et al., 2002)

\section{Pour-Flush Latrine}

- Is a manually flushed water-seal toilet discharging into a pit or leach pit.

- Reduces flies, mosquitoes and odor using a squatting pan with a water seal

- The system with offset pit can be installed inside a household

- Requires water to operate (1.5-2litres per flush)

- The water seal prevents the use of solid anal cleansing materials (Mara et al 2007, Mara, 1985b, Roy et al. (1984, Practical Action )

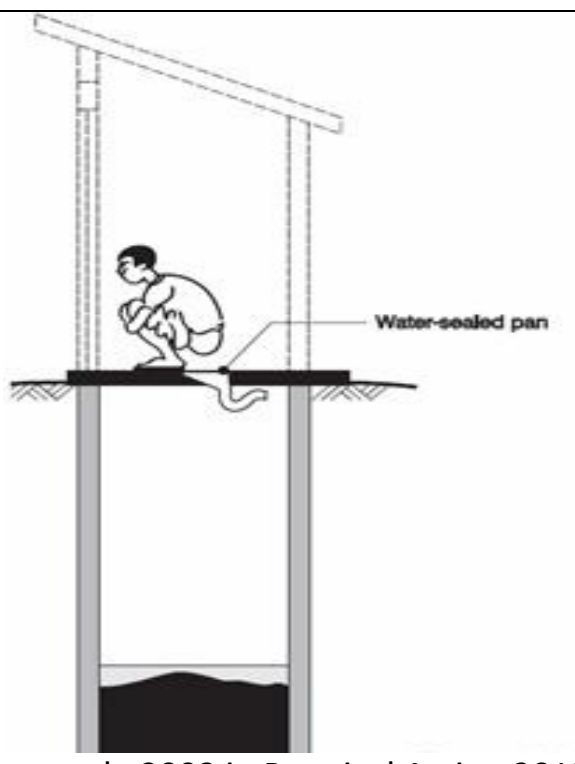

(Harvey et al., 2002 in Practical Action 2012) 
5. EcoSan -Urine diversion dehydration toilet technology (UDDT)

- Recycles nutrients in human excreta (urine and feces) to be used as fertilizer and soil conditioner

- Reduces pollution problems associated with wastewater disposal

- Requires appropriate training of users to ensure the systems are operated correctly and people are not put at risk

- The systems does not accept a wide variety of anal cleansing materials

- May be more expensive than simpler types of latrine

(Practical Action, 2012, Mara 2007)

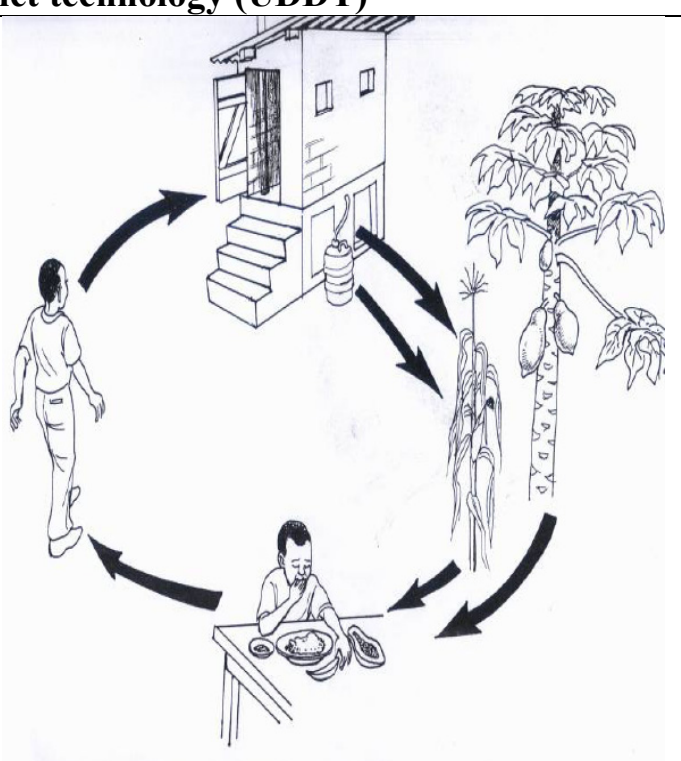

EEPCO, 2010 
Appendix II: Questionnaire

Questionnaire - English Version

\section{ASSESSING SUSTAINABILITY OF SANITATION TECHNOLOGIES RECOMMENDED FOR RURAL AREA OF TANZANIA, A CASES OF MOROGORO DISTRICT}

\section{A: HOUSEHOLD QUESTIONAIRE}

\section{Part 1: Identification}

1. Questionnaire Number.

2. Ward

3. Village / Street.

4. Date / 2011

\section{Part 2: Respondent information}

1. Age (at your last birthday) years

2. Sex
1) Female
2) Male

3. Occupation
1) Employed
2) Non employed
3) Farmer
4) Business
5) Livestock-keeper
6) Home mother
7) Others (specify)

4. Religion
(1) Muslim
(2) Christian (3)
(3) other specify

5. What's your tribe?

6. Household size

1) Number of adults (19 and above).

2) Number of children (5-18).

3) Number of children (0-4) 
7. Population at risk

1) Is there a pregnant woman ( $\mathrm{Yes}=1, \mathrm{No}=2)$

2) People more than 60yrs $(\mathrm{Yes}=1, \mathrm{No}=2)$

8. What is your level of education?
1) No formal education
2) Primary school
3) Secondary
4) College/ university
5) Others (specify) $\ldots \ldots \ldots \ldots \ldots$

\section{Part 3: Existing sanitation situation}

9. Do you have a latrine?
(1) Yes - Go to question \# 15
(2) No - continue to question \# 10

10. If No, did you have one in the past? (1) Yes (2) No

11. What happened to your last latrine? (1) Filled up (2) Pit collapsed (3) Walls and roof collapsed (4) Other specify

12. What reasons stop you from having a latrine now?
1) Collapsing soil in the pit
(1) Yes
(2) No
2) Lack of knowledge / skills of how to build
(1) Yes
(2) No
3) Lack of materials
(1) Yes
(2) No
4) Cost of building high
(1) Yes
(2) No
5) Don't see the need for a latrine
(1) Yes
(2) No
6) Lack of land on which to construct
(1) Yes
(2) No
7) Other specify

13. So, where do members of the household go for their sanitation needs

(1) To the bush (2) Neighbors (3) To the farm - cut and fill (4) Other specify

14. For how long did you use the latrine before you stop using (collapsed/filled up)? yrs.

15. When did you start to live in your house

16. When did you construct your first latrine....

17. When did you stop using your toilet

18. How many times did you construct a toilet for your households ever since you start living here (1) once (2) twice (3) trice (4) every season/ year (5) others specify... 
If the household does not have a toilet, skip Question 19 to 35 and proceed from question 37

19. If yes how many are they? One $=1$, Two $=2$, Three $=3$, Other Specify $\ldots \ldots$.

20. If there is more than one toilet, Why

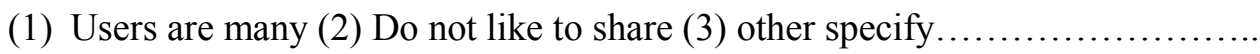

21. For how long have you been using this toilet (2) I don't remember

22. Who built the latrine? (1) Family (2) Fundi (3) Family and Fundi (4) Do not know

23. Are there people trained in building toilets in this area (1) yes (2) No (3) Do not know

24. If they are there, visit one and ask how much does it cost to construct one toilet ......Tshs

25. Approximately how much did the latrine construction cost when you built it?

(1) Tsh........ (2) Do not know

26. Do any neighbors use your latrine?

(1) Yes

(2) No

27. If yes for how long he has been using your latrine (1) Six months (2) One Year (2) More than one year

28. Do you know why they use your toilet (1) Look good than theirs (2) they do not have one (3) Theirs is full (4) Other specify......

29. Do some people from this house use the neighbor's latrine?

(1) Yes

(2) No

30. If yes, Why?

(1) It looks nicer than ours (2) We do not have (3) ours is full (4) Congestion (4) Other specify......

31. Of what type is your toilet (Observe)

1) Traditional Pit Latrine

2) Pit latrine with concrete slab/cement floor

3) Pit latrine fitted with concrete cover slab (SanPlat)

4) Ventilated Improved Pit (VIP) Latrine

5) Pour-flush (PF) toilet

6) Septic tank system

7) EcoSan toilet

32. Is a bath room separated from a toilet (1) Yes (2) No

33. If bathroom is separate why (Tick the most appropriate)

1) It is recommended by experts to restrict gray water from entering the toilet

2) The toilet will fill up quickly

3) We don't like to take a nap in a toilet 
4) Cultural believes

34. Observe the direction of gray water (Tick the most appropriate)

1) Channeled to the toilet pit

2) Directed outside the bathroom to soak away pit

3) Directed outside to the ground

35. If gray water is directed outside the toilet pit, why (tick appropriate)

Toilet pit will fill up quickly

The toilet will produce foul smell

It was restricted by experts

Others specify

36. Is there a hand washing facility outside the toilet (1) yes (2) No

\section{Part 4: Environmental characteristics of the area}

37. What problem do you face when excavating pit

1) Hard soil

2) Hard rock close to the ground

3) Water table high

4) Collapsible soil

5) No problem

6) Do not know

7) Others specify

38. If encountered any problem while constructing your toilet facility, how did you address it

1) Line the pit

2) Excavate shallow pit

3) Elevate the pit

4) Other specify...........

39. How deep do you excavate a pit before you get water (reach water table level) ...... ft

40. Do you experience any disaster e.g. flooding in this area (1) Yes (2) No

41. If yes, when did the last flooding happened (1) One year ago (2) More than two years ago

(3) Other specify

42. Does anyone in your community use latrine products for any of the following uses

1) As fertilizer (1) Yes (2) No

2) Generate energy (1) Yes (2) No 
3) Any uses, specify

43. Local available materials for (cost up to household)

1) Cement at what price/ $50 \mathrm{Kg}$ bag

2) Aggregates (1) tshs...... (2) No cost

3) Sand (1) Tshs (2) No cost

4) Mesh at what price/square meter ..........

5) Price per brick.... Tshs

6) Iron sheet ..... Tsh/sheet

\section{Water supply/water availability}

44. From which water collection point do you get water for drinking purposes?
1) Tap
2) Shallow well
3) River
4) Lake
5) Deep drilled well
6) Dam
7) Spring

45. How far is the water collection point water from home? (m)

1) In between the length of $400 \mathrm{~m}$.

2) More than the length of $400 \mathrm{~m}$.

46. How long does it take you to and from water collection point?

1) More than $30 \mathrm{~min}$

2) Less than $30 \mathrm{~min}$

47. Does the water source operate throughout a year?
1) Yes
2) No

48. If not, when does it cease to operate?

1) During dry season

2) During heavy rain falls

49. During water scarcity, where do you get water from

1) Water venders

2) Neighboring village

3) From river 


\section{Part 4: Problems related to existing sanitation}

50. What were the most common diseases affecting the household members in this year?
1) Diarrhea
(1) Yes
(2) No
2) Worms
(1) Yes
(2) No
3) Cholera
(1) Yes
(2) No
4) Typhoid
(1) Yes
(2) No
5) Eye diseases
(1) Yes
(2) No
6) Dysentery
(1) Yes
(2) No

51. What are the common nuisances related to the sanitation facility currently used?

1) Odor: (1) Yes (2) No

2) Flies/ cockroaches and other vermin: (1) Yes (2) No

3) Gray water (1) Yes (2) No

52. If gray water/sulage is a problem, where does it come from?

1) Hang washing facility (1) Yes (2) No

2) From bathroom : (1) Yes (2) No

\section{Part 4: Household assets and income}

53. Who built the house (a) myself (b) I inherited (c) My children built it for me (d) others explain...............................

54. What type of building material is the main house?

Walls

1) Brick

(1) Yes

(2) No

2) Wattles and mud

(1) Yes

(2) No

3) Other specify

Roof

1) Thatched

2) Iron sheet

3) Tiles

4) Other specify

55. (i) Does household own one of the following items

1) Cow

2) Goat 
3) Poetry

(ii) Cash crops
1) Coconut trees
2) Orange trees
3) Banana tree
4) Others explain.................

(iii) Processions/assets

1. Mobile phone

(1) Yes

(2) No

2. TV

(1) Yes

(2) No

3. Motorcycle

(1) Yes

(2) No

4. Vehicle

(1) Yes

(2) No

5. Others (specify).............. 
Appendix III: Rubrics scale for assigning weight to indicators

\section{Social factor}

\begin{tabular}{|c|c|c|c|}
\hline Indicators & Explanation & Description for rating & Unit \\
\hline \multirow[t]{3}{*}{ Convenience } & \multirow{3}{*}{$\begin{array}{l}\text { Technology easy } \\
\text { to be used by all } \\
\text { family members } \\
\text { especially growing } \\
\text { children and } \\
\text { people with } \\
\text { disability }\end{array}$} & $\begin{array}{l}\text { Technology features may limit young } \\
\text { children, people with disability }\end{array}$ & 0 (low) \\
\hline & & $\begin{array}{l}\text { Residents accept the technology with its } \\
\text { limitation }\end{array}$ & 1 \\
\hline & & $\begin{array}{l}\text { All members in family/ Society can } \\
\text { access with or without slight modification } \\
\text { of a technology }\end{array}$ & 2(high) \\
\hline \multirow[t]{5}{*}{ Conformity } & \multirow{5}{*}{$\begin{array}{l}\text { Conform with } \\
\text { local perception } \\
\text { on material used } \\
\text { to construct a } \\
\text { technology }\end{array}$} & $\begin{array}{l}\text { Number of } \mathrm{HH} \text { with cement floor are } 50 \% \\
\text { and above, highly conform with housing } \\
\text { condition }\end{array}$ & 4 \\
\hline & & $\begin{array}{l}\text { HH with cement floor } 30-49 \% \text {, conform } \\
\text { with housing condition }\end{array}$ & 3 \\
\hline & & $\begin{array}{l}\text { HH with cement floor } 20-29 \text {, conformity } \\
\text { with housing condition is low }\end{array}$ & 2 \\
\hline & & $\begin{array}{l}\text { HH with cement floor } 10-19 \% \\
\text { conformity is very low }\end{array}$ & 1 \\
\hline & & $\begin{array}{l}\text { HH with cement floor } 0-9 \% \text { conformity is } \\
\text { extremely low }\end{array}$ & 0 \\
\hline \multirow[t]{4}{*}{ Acceptability } & \multirow[t]{4}{*}{ Acceptance } & Acceptance $81-100 \%$ & 5 \\
\hline & & Acceptance $71-80 \%$ & 4 \\
\hline & & Acceptance $51-70 \%$ & 3 \\
\hline & & Acceptance $0-50 \%$ & 1 \\
\hline \multirow[t]{3}{*}{ Usability } & \multirow{3}{*}{$\begin{array}{l}\text { Similarity to } \\
\text { common practice } \\
\text { (anal cleansing } \\
\text { practices) }\end{array}$} & $\begin{array}{l}\text { Anal cleansing practices on new } \\
\text { technology is similar to current anal } \\
\text { cleansing practice }\end{array}$ & 2 \\
\hline & & $\begin{array}{l}\text { Anal cleansing practices on new } \\
\text { technology is different from common } \\
\text { practice however the existing practice is } \\
\text { due to limitation of existing technology } \\
\text { than customs (User friendly) }\end{array}$ & 1 \\
\hline & & $\begin{array}{l}\text { Technology introduce new practices on } \\
\text { anal cleansing never practices before in } \\
\text { locality (Not user friendly) }\end{array}$ & 0 \\
\hline
\end{tabular}

- Living in a house with cement floor is prestige and sign of wealthy, resident believe that individuals living in houses with cement floor are most likely to adopt technologies with cement material.

- SanPlat has both cement and dust/mud floor, it was placed in a group of cement floor in this aspect 


\section{Technical/ Technology and operation:}

\begin{tabular}{|c|c|c|c|}
\hline Indicators & Explanation & Description & Unit \\
\hline \multirow[t]{2}{*}{$\begin{array}{l}\text { Material } \\
\text { availability }\end{array}$} & \multirow{2}{*}{$\begin{array}{l}\text { Availability of } \\
\text { material locally } \\
\text { for making a floor }\end{array}$} & Require material available & $\begin{array}{c}1 \\
\text { (Available) }\end{array}$ \\
\hline & & Required material not available & $\begin{array}{c}0 \\
\text { (Unavailable) }\end{array}$ \\
\hline \multirow{2}{*}{$\begin{array}{l}\text { Local labor - } \\
\text { (Use of local } \\
\text { competence } \\
\text { for } \\
\text { construction } \\
\text { and } \\
\text { maintenance) }\end{array}$} & \multirow[t]{2}{*}{$\begin{array}{l}\text { Availability of } \\
\text { required local } \\
\text { labor to } \\
\text { undertake } \\
\text { technical work }\end{array}$} & $\begin{array}{l}\text { Trained artisan required and } \\
\text { available } \\
\text { Or } \\
\text { Trained artisan not necessary for } \\
\text { construct of a facility }\end{array}$ & $\begin{array}{c}1=\text { good } \\
\text { (Available) }\end{array}$ \\
\hline & & $\begin{array}{l}\text { Trained artisan required but not } \\
\text { available }\end{array}$ & $\begin{array}{c}0=\text { bad } \\
\text { (Unavailable) }\end{array}$ \\
\hline \multirow[t]{2}{*}{$\begin{array}{l}\text { Fresh water } \\
\text { requirement }\end{array}$} & \multirow[t]{2}{*}{$\begin{array}{l}\text { Water availability } \\
\text { as required by } \\
\text { technology }\end{array}$} & $\begin{array}{l}\text { Water supply required to run } \\
\text { technology and access is adequate } \\
\text { (at least at intermediate level to } \\
\text { more than } 58.7 \% \text { of } \mathrm{HH} \\
\text { Or } \\
\text { System does not require water } \\
\text { supply for operation except for } \\
\text { hygiene }\end{array}$ & $\begin{array}{c}1=\text { good } \\
\text { (Adequate) }\end{array}$ \\
\hline & & $\begin{array}{l}\text { Water supply required for running a } \\
\text { technology and the access is slow } \\
\text { i.e. less than } 58.7 \% \text { of } \mathrm{HH} \text { access } \\
\text { safe and clean water at intermediate } \\
\text { level }\end{array}$ & $\begin{array}{c}0=\text { bad } \\
\text { (Inadequate) }\end{array}$ \\
\hline
\end{tabular}




\section{Environmental protection and Natural resource use}

\begin{tabular}{|c|c|c|c|}
\hline Indicators & Explanation & Description & Unit \\
\hline \multirow[t]{3}{*}{$\begin{array}{l}\text { Negative } \\
\text { impact on } \\
\text { Environment }\end{array}$} & \multirow{3}{*}{$\begin{array}{l}\text { Impact on } \\
\text { natural forestry } \\
\text { (Rubric } \\
\text { developed as } \\
\text { described in } \\
\text { section } 4.8 \text { ) }\end{array}$} & $\begin{array}{l}\text { Impact on forest is unlikely, because } \\
\text { the technology use concrete slab } \\
\text { instead of wood }\end{array}$ & 2 \\
\hline & & $\begin{array}{l}\text { Minimal impact on forest. Demand for } \\
\text { toilets that would require wood is } \\
\text { lower than national target }\end{array}$ & 1 \\
\hline & & $\begin{array}{l}\text { Impact on forest may be high. } \\
\text { Demand for improved toilets that } \\
\text { require wood is higher than estimated } \\
\text { by the national target }\end{array}$ & 0 \\
\hline \multirow[t]{3}{*}{$\begin{array}{l}\text { Pollution risk to } \\
\text { underground } \\
\text { and surface } \\
\text { water }\end{array}$} & \multirow[t]{3}{*}{$\begin{array}{l}\text { Discharge from } \\
\text { technology may } \\
\text { result into } \\
\text { pollution of } \\
\text { underground } \\
\text { and surface } \\
\text { water }\end{array}$} & $\begin{array}{l}\text { Pit required, ground water table level high } \\
\text { and some HH use shallow well, river, } \\
\text { spring or pond as source of water supply } \\
\text { Or } \\
\text { Leach pit required, gravel and clayed soil } \\
\text { (Infiltration rate likely to be high) yet } \\
\text { some HH use shallow well, river, spring } \\
\text { or pond as source of water supply }\end{array}$ & $\begin{array}{l}(\text { High })=0, \\
\text { worse }\end{array}$ \\
\hline & & $\begin{array}{l}\text { Pit required, ground water table level low } \\
\text { but HH use shallow well, river, spring or } \\
\text { pond as source of water supply }\end{array}$ & $\begin{array}{c}(\text { Likely })=1, \\
\text { bad }\end{array}$ \\
\hline & & $\begin{array}{l}\text { Pit not required or } \\
\text { Whole village supplied by deep well or } \\
\text { tap supplied gravity or treatment plant }\end{array}$ & $\begin{array}{c}(\text { Unlikely })=2, \\
\text { good }\end{array}$ \\
\hline \multirow[t]{3}{*}{$\begin{array}{l}\text { Nutrient } \\
\text { recovery }\end{array}$} & \multirow{3}{*}{$\begin{array}{l}\text { Potential for } \\
\text { recovery of } \\
\text { nutrient from } \\
\text { technology }\end{array}$} & $\begin{array}{l}\text { Nutrients can be recovered and there is a } \\
\text { demand }\end{array}$ & 3 \\
\hline & & $\begin{array}{l}\text { Nutrients can be recovered but resident } \\
\text { does not require }\end{array}$ & 2 \\
\hline & & Nutrients recovery is limited & 1 \\
\hline
\end{tabular}

- *Estimated proportion of HH with improved sanitation in rural is 23\% (NBS 2010)

- Improved floor toilet and SanPlat do not need a household to construct new one-excavate new pit. Due to lack of baseline data however, the assumption was made that $\mathrm{HH}$ will construct new ones. An estimate of $23 \%$ coverage of improved sanitation was used to determine rubric. The width of pit latrine was not known as such was infeasible to ascertain whether ferrocement slab used here for estimation of cost will fit on the existing pit, hence assumption was made also that a household will require to excavate a new pit.

- Environmental impact on forest was estimated based on proportional of people who would require a proposed technology with assumption that, villagers will have to build new ones and use local natural forest as source of logs for the slab/floor. 


\section{Financial and Economic issues/Affordability}

\begin{tabular}{|c|c|c|c|}
\hline Indicators & Explanation & Description & Unit \\
\hline \multirow{4}{*}{$\begin{array}{l}\text { Willingness to } \\
\text { pay for } \\
\text { technology }\end{array}$} & \multirow{4}{*}{$\begin{array}{l}\text { Number of } \\
\text { residents willing } \\
\text { to pay }\end{array}$} & Willingness to pay* of $81-100 \%$ & 3 (High) \\
\hline & & Willingness to pay of $71-80 \%$ & 2 \\
\hline & & Willingness to pay of $51-70 \%$ & 1 \\
\hline & & Willingness to pay of $0-50 \%$ & 0 (Low) \\
\hline \multirow[t]{4}{*}{ Ability to pay } & \multirow[t]{4}{*}{$\begin{array}{l}\text { Social economic } \\
\text { status }\end{array}$} & $\begin{array}{l}\text { No. of least poor and well of greater } \\
\text { than } 51 \%\end{array}$ & $\begin{array}{c}4 \\
\text { (very high) }\end{array}$ \\
\hline & & No. of least poor and well $31-50 \%$ & $\begin{array}{c}3 \\
\text { (High) } \\
\end{array}$ \\
\hline & & No. of least poor and well 11- $30 \%$ & $\begin{array}{c}2 \\
\text { (low) }\end{array}$ \\
\hline & & No. of least poor and well $0-10 \%$ & $\begin{array}{c}1 \\
\text { (Very low) }\end{array}$ \\
\hline \multirow[t]{3}{*}{ Re use potential } & \multirow{3}{*}{$\begin{array}{l}\text { Any material } \\
\text { that can be re } \\
\text { used or } \\
\text { recovered and } \\
\text { lead to savings }\end{array}$} & $\begin{array}{l}\text { Material can be recovered and users } \\
\text { needs }\end{array}$ & $\begin{array}{c}2 \\
\text { (Can be } \\
\text { recovered) }\end{array}$ \\
\hline & & $\begin{array}{l}\text { Material can be recovered but resident } \\
\text { does not require }\end{array}$ & $\begin{array}{c}1 \\
\text { (Can be } \\
\text { recovered but } \\
\text { not required) }\end{array}$ \\
\hline & & $\begin{array}{l}\text { Material required but technology does } \\
\text { not offer opportunity } \\
\text { Or } \\
\text { Material cannot be recovered as well } \\
\text { residents does not require. }\end{array}$ & $\begin{array}{c}0 \\
\text { (Can't be } \\
\text { recovered) }\end{array}$ \\
\hline
\end{tabular}


Appendix IV:

Itemized Costs of Sanitation Technologies in the Study Villages, Morogoro District, Tanzania, 2011

\begin{tabular}{|c|c|c|c|c|c|c|c|c|c|c|c|}
\hline \multicolumn{12}{|c|}{ Technology 1: Improved (floor) Toilet } \\
\hline \multirow[b]{3}{*}{$\begin{array}{l}\text { Materials } \\
\text { need }\end{array}$} & \multirow[b]{3}{*}{$\begin{array}{l}\text { Quantity } \\
\text { needed }\end{array}$} & \multicolumn{10}{|c|}{ Unit cost of material and estimated costs in each village } \\
\hline & & \multicolumn{2}{|c|}{ Changa } & \multicolumn{2}{|c|}{ Fulwe } & \multicolumn{2}{|c|}{ Kalundwa } & \multicolumn{2}{|c|}{ Kinole/Tandai } & \multicolumn{2}{|c|}{ Mkuyuni } \\
\hline & & $\begin{array}{c}\text { Unit cost } \\
\text { of } \\
\text { material }\end{array}$ & $\begin{array}{c}\text { Estimated } \\
\text { cost }\end{array}$ & $\begin{array}{c}\text { Unit cost } \\
\text { of } \\
\text { material }\end{array}$ & $\begin{array}{c}\text { Estimated } \\
\text { cost }\end{array}$ & $\begin{array}{c}\text { Unit cost } \\
\text { of } \\
\text { material }\end{array}$ & $\begin{array}{c}\text { Estimated } \\
\text { cost }\end{array}$ & $\begin{array}{c}\text { Unit cost } \\
\text { of } \\
\text { material }\end{array}$ & $\begin{array}{c}\text { Estimated } \\
\text { cost }\end{array}$ & $\begin{array}{c}\text { Unit cost } \\
\text { of } \\
\text { material }\end{array}$ & $\begin{array}{c}\text { Estimated } \\
\text { cost }\end{array}$ \\
\hline Cement & $\begin{array}{l}0.25 \text { of a } \\
\text { bag }\end{array}$ & $\begin{array}{l}15,000 / \\
50 \mathrm{Kgs}\end{array}$ & 3,750 & $\begin{array}{l}14,000 / \\
50 \mathrm{Kgs}\end{array}$ & 3,500 & $\begin{array}{l}15,000 / \\
50 \mathrm{Kgs}\end{array}$ & 3,750 & $\begin{array}{l}16,000 / \\
50 \mathrm{Kgs}\end{array}$ & 4000 & $\begin{array}{l}15,000 / \\
50 \mathrm{Kgs}\end{array}$ & 3750 \\
\hline Sand & 2 buckets & 200 & 400 & 300 & 600 & 300 & 600 & 400 & 800 & 200 & 400 \\
\hline Logs (6 pieces) & $6 \operatorname{logs}$ & 2500 & 15,000 & 4000 & 24,000 & 2500 & 15,000 & 3000 & 18,000 & 3000 & 18,000 \\
\hline Pit excavation & 1 & 35,000 & 35,000 & 40,000 & 40,000 & 30,000 & 30,000 & 40,000 & 40,000 & 35,000 & 35,000 \\
\hline Total & & & 54,150 & & 68,100 & & 49,350 & & 62,800 & & 63,150 \\
\hline
\end{tabular}

\begin{tabular}{|c|c|c|c|c|c|c|c|c|c|c|c|}
\hline \multicolumn{12}{|c|}{ Technology 2: SanPlat Toilet } \\
\hline \multirow[b]{3}{*}{$\begin{array}{l}\text { Materials } \\
\text { need }\end{array}$} & \multirow[b]{3}{*}{$\begin{array}{l}\text { Quantity } \\
\text { needed }\end{array}$} & \multicolumn{10}{|c|}{ Unit cost of material and estimated costs in each village } \\
\hline & & \multicolumn{2}{|c|}{ Changa } & \multicolumn{2}{|c|}{ Fulwe } & \multicolumn{2}{|c|}{ Kalundwa } & \multicolumn{2}{|c|}{ Kinole/Tandai } & \multicolumn{2}{|c|}{ Mkuyuni } \\
\hline & & $\begin{array}{c}\text { Unit } \\
\text { price of } \\
\text { material } \\
\end{array}$ & $\begin{array}{c}\text { Estimated } \\
\text { cost }\end{array}$ & $\begin{array}{c}\text { Unit } \\
\text { price of } \\
\text { material }\end{array}$ & $\begin{array}{c}\text { Estimated } \\
\text { cost }\end{array}$ & $\begin{array}{c}\text { Unit price } \\
\text { of } \\
\text { material }\end{array}$ & $\begin{array}{c}\text { Estimated } \\
\text { cost }\end{array}$ & $\begin{array}{c}\text { Unit } \\
\text { price of } \\
\text { material }\end{array}$ & $\begin{array}{c}\text { Estimated } \\
\text { cost }\end{array}$ & $\begin{array}{c}\text { Unit } \\
\text { price of } \\
\text { material }\end{array}$ & $\begin{array}{c}\text { Estimated } \\
\text { cost }\end{array}$ \\
\hline Cement & $\begin{array}{l}0.125 \text { of a } \\
\text { bag }\end{array}$ & 15,000 & 1,750 & 14,000 & 1750 & 15,000 & 1,750 & 16,000 & 2,000 & 15,000 & 1750 \\
\hline $\begin{array}{l}\text { Welded mesh } \\
(2.4 \mathrm{~m} \times 1.2 \mathrm{~m})\end{array}$ & 0.125 & 15,000 & 1,875 & 14,000 & 1750 & 16,000 & 2,000 & 16,500 & 2,063 & 15,000 & 1875 \\
\hline Sand & 300 & $\begin{array}{l}200 / \\
\text { Bucket }\end{array}$ & 200 & 1 Bucket & 300 & $\begin{array}{l}300 / \\
\text { Bucket }\end{array}$ & 300 & $\begin{array}{l}400 / \text { Buck } \\
\text { et }\end{array}$ & 400 & $\begin{array}{l}\text { 200/Buck } \\
\text { et }\end{array}$ & 200 \\
\hline Logs (6 pieces) & $6 \operatorname{logs}$ & 2500 & 15,000 & 4000 & 24,000 & 2500 & 15,000 & 3000 & 18,000 & 3000 & 18,000 \\
\hline Pit excavation & 1 & 35,000 & 35,000 & 40,000 & 40,000 & 30,000 & 30,000 & 40,000 & 40,000 & 35,000 & 35,000 \\
\hline Total & & & 53,825 & & 67,800 & & 49,050 & & 62,463 & & 54,950 \\
\hline
\end{tabular}




\begin{tabular}{|c|c|c|c|c|c|c|c|c|c|c|c|}
\hline \multicolumn{12}{|c|}{ Technology 3: VIP Latrine } \\
\hline \multirow[b]{3}{*}{$\begin{array}{l}\text { Materials } \\
\text { need }\end{array}$} & \multirow[b]{3}{*}{$\begin{array}{l}\text { Quantity } \\
\text { needed }\end{array}$} & \multicolumn{10}{|c|}{ Unit cost of material and estimated costs in each village } \\
\hline & & \multicolumn{2}{|c|}{ Changa } & \multicolumn{2}{|c|}{ Fulwe } & \multicolumn{2}{|c|}{ Kalundwa } & \multicolumn{2}{|c|}{ Kinole/Tandai } & \multicolumn{2}{|c|}{ Mkuyuni } \\
\hline & & $\begin{array}{c}\text { Unit } \\
\text { price of } \\
\text { material }\end{array}$ & $\begin{array}{c}\text { Estimated } \\
\text { cost }\end{array}$ & $\begin{array}{c}\text { Unit } \\
\text { price of } \\
\text { material }\end{array}$ & $\begin{array}{c}\text { Estimated } \\
\text { cost }\end{array}$ & $\begin{array}{c}\text { Unit price } \\
\text { of } \\
\text { material }\end{array}$ & $\begin{array}{c}\text { Estimated } \\
\text { cost }\end{array}$ & $\begin{array}{c}\text { Unit } \\
\text { price of } \\
\text { material }\end{array}$ & $\begin{array}{c}\text { Estimated } \\
\text { cost }\end{array}$ & $\begin{array}{c}\text { Unit } \\
\text { price of } \\
\text { material }\end{array}$ & $\begin{array}{c}\text { Estimated } \\
\text { cost }\end{array}$ \\
\hline Cement & $\begin{array}{l}0.50 \text { of the } \\
\text { bag }\end{array}$ & $\begin{array}{l}15,000 / \\
50 \mathrm{Kgs}\end{array}$ & 7500 & $\begin{array}{l}14,000 / \\
50 \mathrm{Kgs}\end{array}$ & 7000 & $\begin{array}{l}15,000 / \\
50 \mathrm{Kgs}\end{array}$ & 7500 & $\begin{array}{l}16,000 / \\
50 \mathrm{Kgs}\end{array}$ & 8000 & $\begin{array}{l}15,000 / \\
50 \mathrm{Kgs}\end{array}$ & 7500 \\
\hline Sand & 3 buckets & $\begin{array}{l}200 / \\
\text { bucket }\end{array}$ & 600 & $\begin{array}{l}300 / \\
\text { bucket }\end{array}$ & 900 & $\begin{array}{l}300 / \\
\text { bucket }\end{array}$ & 900 & $\begin{array}{l}400 / \\
\text { bucket }\end{array}$ & 1200 & $\begin{array}{l}200 / \\
\text { bucket }\end{array}$ & 600 \\
\hline Aggregates & 3 buckets & 500 & 1,500 & 600 & 1,800 & 500 & 1,500 & 500 & 1,500 & 500 & 1,500 \\
\hline $\begin{array}{l}\text { Welded mesh } \\
(2.4 \mathrm{~m} \times 1.2 \mathrm{~m})\end{array}$ & 0.5 & 15,000 & 7,500 & 14,000 & 7,000 & 16,000 & 8,000 & 16,500 & 8,250 & 15,000 & 7,500 \\
\hline Vent pipe & $1 \mathrm{pc}$ & 15,000 & 15,000 & 14,500 & 14,500 & 15,500 & 15,500 & 16,500 & 16,500 & 15,000 & 15,000 \\
\hline Pit excavation & 1 & 35,000 & 35,000 & 40,000 & 40,000 & 30,000 & 30,000 & 40,000 & 40,000 & 35,000 & 35,000 \\
\hline Total & & & 67,100 & & 71,200 & & 63,400 & & 75,450 & & 67,100 \\
\hline
\end{tabular}

\begin{tabular}{|c|c|c|c|c|c|c|c|c|c|c|c|}
\hline \multicolumn{12}{|c|}{ Technology 4: Pour Flush Latrine } \\
\hline \multirow[b]{3}{*}{$\begin{array}{l}\text { Materials } \\
\text { need }\end{array}$} & \multirow[b]{3}{*}{$\begin{array}{l}\text { Quantity } \\
\text { needed }\end{array}$} & \multicolumn{10}{|c|}{ Unit cost of material and estimated costs in each village } \\
\hline & & \multicolumn{2}{|c|}{ Changa } & \multicolumn{2}{|c|}{ Fulwe } & \multicolumn{2}{|c|}{ Kalundwa } & \multicolumn{2}{|c|}{ Kinole/Tandai } & \multicolumn{2}{|c|}{ Mkuyuni } \\
\hline & & $\begin{array}{c}\text { Unit } \\
\text { price of } \\
\text { material } \\
\end{array}$ & $\begin{array}{c}\text { Estimated } \\
\text { cost }\end{array}$ & $\begin{array}{c}\text { Unit } \\
\text { price of } \\
\text { material } \\
\end{array}$ & $\begin{array}{c}\text { Estimated } \\
\text { cost }\end{array}$ & $\begin{array}{c}\text { Unit price } \\
\text { of } \\
\text { material }\end{array}$ & $\begin{array}{c}\text { Estimated } \\
\text { cost }\end{array}$ & $\begin{array}{c}\text { Unit } \\
\text { price of } \\
\text { material } \\
\end{array}$ & $\begin{array}{c}\text { Estimated } \\
\text { cost }\end{array}$ & $\begin{array}{c}\text { Unit } \\
\text { price of } \\
\text { material } \\
\end{array}$ & $\begin{array}{c}\text { Estimated } \\
\text { cost }\end{array}$ \\
\hline Cement & $\begin{array}{l}0.50 \text { of the } \\
\text { bag }\end{array}$ & $\begin{array}{l}15,000 / \\
50 \mathrm{Kgs} \\
\end{array}$ & 7,500 & $\begin{array}{l}14,000 / \\
50 \mathrm{Kgs} \\
\end{array}$ & 7000 & $\begin{array}{l}15,000 / \\
50 \mathrm{Kgs} \\
\end{array}$ & 7,500 & $\begin{array}{l}16,000 / \\
50 \mathrm{Kgs} \\
\end{array}$ & 8,000 & $\begin{array}{l}15,000 / \\
50 \mathrm{Kgs} \\
\end{array}$ & 7,500 \\
\hline Sand & 3 buckets & 200 & 600 & 300 & 900 & 300 & 600 & 400 & 1,200 & 200 & 600 \\
\hline Aggregates & 3 buckets & 500 & 1,500 & 600 & 1,800 & 500 & 1,500 & 500 & 1,500 & 500 & 1,500 \\
\hline $\begin{array}{l}\text { Welded mesh } \\
(2.4 \mathrm{~m} \times 1.2 \mathrm{~m})\end{array}$ & 0.5 a roll & 15,000 & 7,500 & 14,000 & 7,000 & 16,000 & 7,500 & 16,500 & 8,250 & 15,000 & 7,500 \\
\hline $\begin{array}{l}\text { Squatting Pan } \\
\text { and trap unit }\end{array}$ & $1 \mathrm{Pc}$ & 18,000 & 18,000 & 18,000 & 18,000 & 18,000 & 18,000 & 18,000 & 18,000 & 18,000 & 18,000 \\
\hline $\begin{array}{l}\text { Water for } \\
\text { running }\end{array}$ & $\begin{array}{l}2- \\
\text { 3Lts/plush }\end{array}$ & 0 & 0 & 0 & 0 & & 0 & 0 & 0 & 0 & 0 \\
\hline \multirow[t]{2}{*}{ Pit excavation } & & 35,000 & 35,000 & 40,000 & 40,000 & 30,000 & 30,000 & 40,000 & 40,000 & 35,000 & 35,000 \\
\hline & & & 70,100 & & 74,700 & & 65,100 & & 76,950 & & 70,100 \\
\hline
\end{tabular}




\begin{tabular}{|c|c|c|c|c|c|c|c|c|c|c|c|}
\hline \multicolumn{12}{|c|}{ Technology 5: EcoSan } \\
\hline \multirow[b]{3}{*}{$\begin{array}{l}\text { Materials } \\
\text { need }\end{array}$} & \multirow[b]{3}{*}{$\begin{array}{l}\text { Quantity } \\
\text { needed }\end{array}$} & \multicolumn{10}{|c|}{ Unit cost of material and estimated costs in each village } \\
\hline & & \multicolumn{2}{|c|}{ Changa } & \multicolumn{2}{|c|}{ Fulwe } & \multicolumn{2}{|c|}{ Kalundwa } & \multicolumn{2}{|c|}{ Kinole/Tandai } & \multicolumn{2}{|c|}{ Mkuyuni } \\
\hline & & $\begin{array}{c}\text { Unit } \\
\text { price of } \\
\text { material }\end{array}$ & $\begin{array}{c}\text { Estimated } \\
\text { cost }\end{array}$ & $\begin{array}{c}\text { Unit } \\
\text { price of } \\
\text { material }\end{array}$ & $\begin{array}{c}\text { Estimate } \\
\text { d cost }\end{array}$ & $\begin{array}{c}\text { Unit } \\
\text { price of } \\
\text { material }\end{array}$ & $\begin{array}{l}\text { Estimated } \\
\text { cost }\end{array}$ & $\begin{array}{c}\text { Unit } \\
\text { price of } \\
\text { materia } \\
\text { l }\end{array}$ & $\begin{array}{c}\text { Estimate } \\
\text { d cost }\end{array}$ & $\begin{array}{c}\text { Unit } \\
\text { price of } \\
\text { materia } \\
\text { l }\end{array}$ & $\begin{array}{c}\text { Estimate } \\
\text { d cost }\end{array}$ \\
\hline Substructure & - & - & 341,700 & - & 341,700 & - & 341,700 & - & 341,700 & - & 341,700 \\
\hline Squatting pans & - & - & 85,500 & - & 85,500 & - & 85,500 & - & 85,500 & - & 85,500 \\
\hline Total & & & $427,200 *$ & & $427,200 *$ & & $427,200 *$ & & $427,200 *$ & & $427,200 *$ \\
\hline
\end{tabular}


Appendix V

General Perceptions of Households about the Study Sanitation Technologies

\begin{tabular}{|c|c|c|c|c|c|}
\hline \multirow[b]{2}{*}{ Technology } & \multicolumn{5}{|c|}{ Respondent's reaction on proposed technologies in each village } \\
\hline & Changa & Fulwe & Kalundwa & Kinole/Tandai & Mkuyuni \\
\hline $\begin{array}{l}\text { Improved } \\
\text { Floor Toilet }\end{array}$ & $\begin{array}{ll}\text { - } & \text { Simple and } \\
\text { affordable } \\
\text { - } \\
\text { Local masonry can } \\
\text { construct one- } \\
\text { Skilled personnel } \\
\text { can be expensive }\end{array}$ & $\begin{array}{l}\text { - } \\
\text { - } \\
\text { Cample and affordable } \\
\text { improved/modified } \\
\text { e.g. to use water or } \\
\text { insert a vent pipe } \\
\text { inability to control } \\
\text { odor and flies is } \\
\text { discouraging }\end{array}$ & $\begin{array}{ll}\text { - } & \text { Simple and } \\
\text { affordable } \\
\text { - } & \text { Local mason can } \\
\text { construct one }\end{array}$ & $\begin{array}{ll}\text { - } & \text { Simple and } \\
\text { affordable } \\
\text { - } & \text { Local mason can } \\
\text { construct one }\end{array}$ & $\begin{array}{ll}\text { - } & \text { Simple and affordable } \\
\text { - } & \text { Can easily be } \\
\text { improved/modified e.g. to } \\
\text { use water or insert a vent } \\
\text { pipe into it } \\
\text { - Local masonry can } \\
\text { construct one- Skilled } \\
\text { personnel can be } \\
\text { expensive }\end{array}$ \\
\hline SanPlat & $\begin{array}{l}\text { - } \\
\text { No trained } \\
\text { personnel } \\
\text { Time may be } \\
\text { required before the } \\
\text { slab is re used, may } \\
\text { be two slab may be } \\
\text { required for } \\
\text { alternation }\end{array}$ & 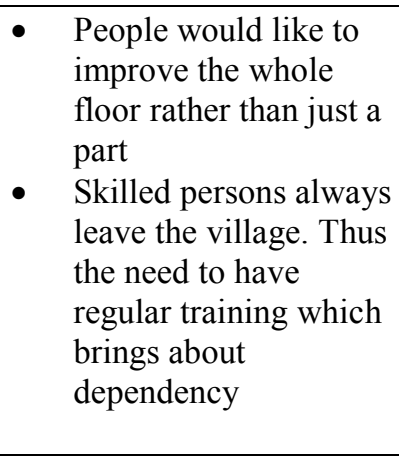 & $\begin{array}{l}\text { - } \\
\text { po trained } \\
\text { personnel } \\
\text { Technology was } \\
\text { perceived as new } \\
\text { and there was } \\
\text { hesitance on } \\
\text { showing voting } \\
\text { for technology to } \\
\text { indicate their } \\
\text { willingness to pay }\end{array}$ & $\begin{array}{ll}\text { - } & \text { No trained } \\
\text { personnel } \\
\text { - } & \text { Simple and } \\
\text { affordable } \\
\text { - } & \text { Demand training } \\
\text { on construction of } \\
\text { those new } \\
\text { technologies }\end{array}$ & $\begin{array}{l}\text { - Skilled persons always } \\
\text { leave the village. Thus the } \\
\text { need to have regular } \\
\text { training which brings } \\
\text { about dependency } \\
\text { - During cleaning edges of } \\
\text { the SanPlat can wet bare } \\
\text { soil/ mud floor around it } \\
\text { After a toilet is full, one } \\
\text { might need time before } \\
\text { taking a floor and reuse }\end{array}$ \\
\hline $\begin{array}{l}\text { VIP } \\
\text { latrine }\end{array}$ & $\begin{array}{l}\text { Will be expensive } \\
\text { for majority } \\
\text { - Looks more } \\
\text { improved than } \\
\text { main household }\end{array}$ & $\begin{array}{l}\text { Darkness is not an } \\
\text { issue children can } \\
\text { learn and adopt } \\
\text { Demonstration toilet } \\
\text { needed for continuous } \\
\text { learning "Choo } \\
\text { darasa" }\end{array}$ & 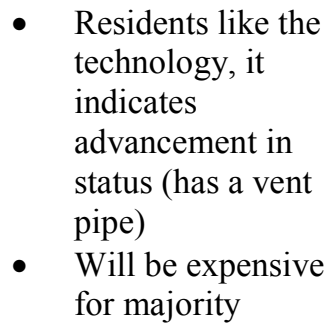 & $\begin{array}{l}\text { Residents like the } \\
\text { technology, it } \\
\text { indicates } \\
\text { advancement in } \\
\text { status }\end{array}$ & $\begin{array}{l}\text { - } \quad \text { It controls smell } \\
\text { - } \quad \text { Expensive } \\
\text { Looks more improved } \\
\text { than main household - } \\
\text { "better improve main } \\
\text { house first" }\end{array}$ \\
\hline
\end{tabular}




\begin{tabular}{|c|c|c|c|c|c|}
\hline Pour Flush & $\begin{array}{ll}\text { - } & \text { Water supply not } \\
\text { reliable } \\
\text { - } & \text { Expensive } \\
\text { - } & \text { Majority are } \\
\text { Muslim, use water } \\
\text { for anal cleansing. }\end{array}$ & $\begin{array}{l}\text { Local modification are } \\
\text { always made to reduce } \\
\text { water use: High slope } \\
\text { and addition of oil } \\
\text { Use it when taking } \\
\text { shower } \\
\text { - Sanitary pads treated } \\
\text { as normal waste } \\
\text { When educated, user } \\
\text { find means to meet } \\
\text { objective } \\
\text { Majority are Muslim, } \\
\text { use water for anal } \\
\text { cleansing }\end{array}$ & $\begin{array}{l}\text { Water supply not } \\
\text { reliable but } \\
\text { residents felt that } \\
\text { choosing the } \\
\text { technology will } \\
\text { help influence the } \\
\text { government to } \\
\text { supply water in } \\
\text { their village } \\
\text { Expensive to } \\
\text { majority }\end{array}$ & $\begin{array}{l}\text { Access to water } \\
\text { high, but resident } \\
\text { afraid of frequent } \\
\text { pit collapse due to } \\
\text { high rainfall, run } \\
\text { off and } \\
\text { topography } \\
\text { Pit may collapse } \\
\text { since water is } \\
\text { allowed in the pit }\end{array}$ & $\begin{array}{ll}\text { - } & \text { Water supply is not a } \\
\text { problem } \\
\text { - } & \text { Expensive } \\
\text { - } & \text { Girls use non disposable } \\
\text { sanitary pads } \\
\text { - } \\
\text { Majority are Muslim, use } \\
\text { water for anal cleansing }\end{array}$ \\
\hline EcoSan & 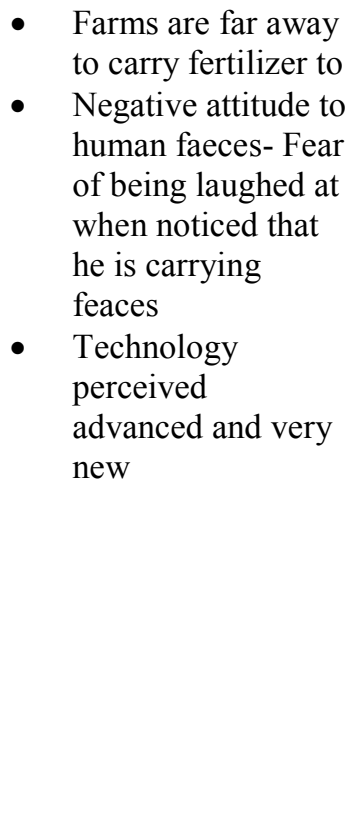 & $\begin{array}{l}\text { Technically infeasible } \\
\text { need skilled personnel } \\
\text { to construct and care } \\
\text { to maintain } \\
\text { Cleansing aside is not } \\
\text { an issue because } \\
\text { people do so to avoid } \\
\text { wetting mud floor } \\
\text { The land is still fertile- } \\
\text { no need of human } \\
\text { fertilizer } \\
\text { Lack of market when } \\
\text { customer figure out } \\
\text { that human manure } \\
\text { was used as fertilizer } \\
\text { Handling of urine } \\
\text { frequently is unsightly } \\
\text { Pilot EcoSan was } \\
\text { abandoned at Fulwe } \\
\text { Primary School. }\end{array}$ & $\begin{array}{l}\text { Farms are far } \\
\text { away to carry } \\
\text { fertilizer to. Farms } \\
\text { were across the } \\
\text { river where they } \\
\text { were forced to } \\
\text { leave during } \\
\text { villagization } \\
\text { Negative attitude } \\
\text { on handling } \\
\text { human faeces } \\
\text { One can even stop } \\
\text { excavating new } \\
\text { and change to } \\
\text { another place if } \\
\text { during excavation } \\
\text { he discovers sign } \\
\text { of decomposed. }\end{array}$ & $\begin{array}{l}\text { Farms for maize } \\
\text { and paddy are far } \\
\text { away compared to } \\
\text { fruit plots. } \\
\text { People fear that if } \\
\text { used in pineapples } \\
\text { people would not } \\
\text { buy or may be } \\
\text { easy to construct } \\
\text { diarhoea for fruits } \\
\text { are eaten raw } \\
\text { Negative attitude } \\
\text { on handling } \\
\text { human faeces }\end{array}$ & $\begin{array}{l}\text { Area is mountainous, } \\
\text { there might be a problem } \\
\text { when the toilet of a } \\
\text { neighbor from higher } \\
\text { elevation collapses due to } \\
\text { heavy rain and runoff } \\
\text { Technical skills is needed } \\
\text { can be more expensive } \\
\text { Urine and excreta are } \\
\text { filthy, one cannot eat food } \\
\text { stuff fertilized by those }\end{array}$ \\
\hline
\end{tabular}


Appendix VI

An Illustration of the Development of Sustainability Indicator Values:

The Case of Changa Village and SanPlat Toilet

Factor 1: Social cultural and institutional aspects

\begin{tabular}{|c|c|c|c|c|c|c|c|c|c|}
\hline Indicators & Requirement & Local condition & Impact & Value & $\begin{array}{l}\text { Normalized } \\
\text { Indicators }\end{array}$ & $\begin{array}{l}\text { Weight } \\
\text { of } \\
\text { indicator }\end{array}$ & $\begin{array}{l}\text { Sustainability } \\
\text { sub index } \\
\text { (Isi) }\end{array}$ & $\begin{array}{c}\text { Weight } \\
\text { of } \\
\text { factors } \\
\text { (Wj) } \\
\end{array}$ & $\begin{array}{l}\text { Sustainability } \\
\text { index (Is)= } \\
\text { Wj*Isji }^{*}=\end{array}$ \\
\hline Convenience & $\begin{array}{l}\text { SanPlat has a drop } \\
\text { hole of a size user } \\
\text { friendly to children }\end{array}$ & $\begin{array}{l}\text { Young children and } \\
\text { adults use same toilets }\end{array}$ & $(+)$ & 1 & 1 & 0.25 & 0.25 & & \\
\hline Conformity & $\begin{array}{l}\text { Conform to } \\
\text { material used to } \\
\text { build a main house } \\
\text { (floor). }\end{array}$ & $\begin{array}{l}\text { HH with mud floor } \\
89 \% \\
\text { HH with cement floor } \\
11 \%\end{array}$ & $(+)$ & 1 & 1 & 0.25 & 0.25 & & \\
\hline Usability & $\begin{array}{l}\text { Anal cleansing take } \\
\text { place over squatting } \\
\text { hole }\end{array}$ & $\begin{array}{l}\text { HH with simple pit } \\
\text { latrine with mud floor } \\
\text { perform anal } \\
\text { cleansing aside the pit } \\
\text { hole to avoid wetting } \\
\text { floor. Those with } \\
\text { improved perform } \\
\text { anal cleansing using } \\
\text { water on the drop hole }\end{array}$ & $(+)$ & 1 & 1 & 0.25 & 0.25 & & \\
\hline \multirow[t]{2}{*}{ To Acceptability } & Accepted by users & Acceptance $62.5 \%$ & $(+)$ & 3 & 0.5 & 0.25 & 0.125 & & \\
\hline & & & & & & 1 & 0.875 & $\mathbf{0 . 5 3 0}$ & 0.464 \\
\hline
\end{tabular}


Factor 2: Technology and operation- technical feasibility

\begin{tabular}{|c|c|c|c|c|c|c|c|c|c|}
\hline Indicators & Requirement & Local condition & Impact & Value & $\begin{array}{l}\text { Normalized } \\
\text { Indicators }\end{array}$ & $\begin{array}{l}\text { Weight } \\
\text { of } \\
\text { indicator }\end{array}$ & $\begin{array}{l}\text { Sustainability } \\
\text { sub index } \\
\text { (Isi) }\end{array}$ & $\begin{array}{l}\text { Weight } \\
\text { of } \\
\text { factors } \\
(\mathbf{W j})\end{array}$ & $\begin{array}{l}\text { Sustainability } \\
\text { index }(I s)= \\
\text { Wj*Isji }\end{array}$ \\
\hline $\begin{array}{l}\text { Availability } \\
\text { of material } \\
\text { locally }\end{array}$ & $\begin{array}{l}\text { Hardwood poles } \\
\text { with a diameter not } \\
\text { less than } 100 \mathrm{~mm} \\
\text { required }\end{array}$ & $\begin{array}{l}2.84 \mathrm{Km} 2 \text { is natural } \\
\text { forest and } 9.92 \mathrm{KM} 2 \\
\text { is a village reserved } \\
\text { forest }\end{array}$ & $(+)$ & 1 & 1 & 0.25 & 0.25 & & \\
\hline $\begin{array}{l}\text { Local } \\
\text { labor/skills }\end{array}$ & $\begin{array}{l}\text { Trained artisan } \\
\text { required }\end{array}$ & $\begin{array}{l}\text { Local artisans available } \\
\text { but not trained }\end{array}$ & $(-)$ & 0 & 1 & 0.25 & 0.25 & & \\
\hline $\begin{array}{l}\text { Fresh water } \\
\text { need for } \\
\text { operation and } \\
\text { hygiene }\end{array}$ & $\begin{array}{l}\text { Minimum } \\
\text { requirement per } \\
\text { person per day }\end{array}$ & $\begin{array}{l}\text { Basic access }(5-30 \mathrm{Min} \text { is } \\
\text { spent to fetch water from } \\
\text { collection point; shallow } \\
\text { wells } 49 \% \text {, deep well } \\
44 \% \text {, river } 7 \% \text { ) }\end{array}$ & $(-)$ & 1 & 0 & 0.25 & 0 & & \\
\hline \multirow[t]{2}{*}{ Compatibility } & $\begin{array}{l}\text { All kinds of anal } \\
\text { cleansing material } \\
\text { can be used (Solid } \\
\text { or water) }\end{array}$ & $\begin{array}{l}\text { Residents use water for } \\
\text { anal cleansing }\end{array}$ & $(+)$ & 1 & 1 & 0.25 & 0.25 & & \\
\hline & & & & & & 1 & 0.25 & 0.150 & 0.038 \\
\hline
\end{tabular}


Factor 3: Environmental Impact and Natural Resource

\begin{tabular}{|c|c|c|c|c|c|c|c|c|c|}
\hline Indicators & Requirement & Local condition & Impact & $\begin{array}{l}\text { Valu } \\
\text { e }\end{array}$ & $\begin{array}{l}\text { Normalized } \\
\text { Indicators }\end{array}$ & $\begin{array}{l}\text { Weight } \\
\text { of } \\
\text { indicator }\end{array}$ & $\begin{array}{l}\text { Sustaina } \\
\text { bility sub } \\
\text { index } \\
\text { (Isi) }\end{array}$ & $\begin{array}{l}\text { Weigh } \\
t \text { of } \\
\text { factor } \\
s(W j)\end{array}$ & $\begin{array}{l}\text { Sustainabi } \\
\text { lity index } \\
\text { (Is)= } \\
\text { Wj*Isji }\end{array}$ \\
\hline $\begin{array}{l}\text { Impact on } \\
\text { forestry }\end{array}$ & $\begin{array}{l}\text { Hard wood } \\
\text { required }\end{array}$ & $\begin{array}{l}2 \% \text { have improved toilets. } \\
33.5 \% \text { increase is required to } \\
\text { reach a target of } 35.5 \% \\
\text { coverage of improved sanitation } \\
\text { by } 2015 \quad \text { Natural forest } \\
2.84 \mathrm{SqKM} \text {. Estimated impact } \\
0.144 \mathrm{SqKM}\end{array}$ & $(-)$ & 0 & 1.000 & 0.333 & 0.333 & & \\
\hline \multirow[t]{2}{*}{$\begin{array}{l}\text { Pollution risk to } \\
\text { water sources } \\
\text { (ground and } \\
\text { surface) }\end{array}$} & $\begin{array}{l}\text { Min pit depth, } \\
2-3 \mathrm{M} \text {, } \\
2 \mathrm{M} \text { above } \\
\text { water table }\end{array}$ & $\begin{array}{l}\text { Technology will have impact } \\
\text { on natural forest. If adopted the } \\
\text { impact will be higher than } \\
\text { expected (Demand is } 33 \% \text {, } \\
\text { expected demand was estimated } \\
\text { to be } 12 \% \text { of } \mathrm{HH} \text { ) }\end{array}$ & $(-)$ & 1 & 0 & 0.333 & 0.000 & & \\
\hline & $\begin{array}{l}\text { Locate } 15 \mathrm{M} \\
\text { away from } \\
\text { water } \\
\text { abstraction } \\
\text { point (shallow } \\
\text { well, river, } \\
\text { pond, spring) }\end{array}$ & & & & & & 0.000 & & \\
\hline \multirow[t]{2}{*}{ Nutrient recovery } & $\begin{array}{l}\text { Access to } \\
\text { nutrient is } \\
\text { limited }\end{array}$ & $\begin{array}{l}\text { Residents do not require excreta } \\
\text { material for any use. }\end{array}$ & $(+)$ & 1 & 0 & 0.333 & 0.000 & & \\
\hline & & & & & & 1.00 & -0.333 & 0.070 & -0.023 \\
\hline
\end{tabular}


Factor 4: Economic and Financial-affordability

\begin{tabular}{|c|c|c|c|c|c|c|c|c|c|}
\hline Indicators & Requirement & Local condition & Impact & $\begin{array}{l}\text { Valu } \\
\text { e }\end{array}$ & $\begin{array}{l}\text { Normali } \\
\text { zed } \\
\text { Indicato } \\
\text { rs }\end{array}$ & $\begin{array}{l}\text { Weight of } \\
\text { indicator }\end{array}$ & $\begin{array}{c}\text { Sustainabili } \\
\text { ty sub } \\
\text { index (Isi) }\end{array}$ & $\begin{array}{l}\text { Weight } \\
\text { of } \\
\text { factors } \\
(\mathbf{W j})\end{array}$ & $\begin{array}{l}\text { Sustainabi } \\
\text { lity index } \\
\text { (Is)= } \\
\text { Wj*Isji }\end{array}$ \\
\hline $\begin{array}{l}\text { Willingness to } \\
\text { pay }\end{array}$ & $\begin{array}{l}\text { TZS 53,825 for } \\
\text { improving floor and pit } \\
\text { excavation }\end{array}$ & $\begin{array}{l}\text { Willing to pay } 75 \% \text { of } \\
\text { FGD participants }\end{array}$ & $(+)$ & 2 & 1 & 0.3 & 0.330 & & \\
\hline $\begin{array}{l}\text { Ability to pay } \\
\text { for capital cost }\end{array}$ & $\begin{array}{l}\text { Capital cost TZS } \\
54,150\end{array}$ & $\begin{array}{l}\text { Number of least poor } \\
\text { and well off } 35 \%\end{array}$ & $(+)$ & 3 & 0.667 & 0.3 & 0.220 & & \\
\hline \multirow[t]{2}{*}{$\begin{array}{l}\text { Material } \\
\text { recovery or re } \\
\text { use }\end{array}$} & $\begin{array}{l}\text { SanPlat slab can be re } \\
\text { used }\end{array}$ & $\begin{array}{l}\text { Users can save } 3,825 \\
\text { for a reused Sanplat } \\
\text { slab in new toilet yet } \\
\text { not willing to re use }\end{array}$ & $(+)$ & 1 & 0.5 & 0.3 & 0.165 & & \\
\hline & & & & & & 1.0 & 0.715 & 0.250 & 0.179 \\
\hline $\begin{array}{c}\text { CSDI (Sum of } \\
\text { Is) }\end{array}$ & & & & & & & & & 0.657 \\
\hline
\end{tabular}

